\title{
Primary Care Relevant Risk Factors for Adverse Outcomes in Patients With COVID-19 Infection: A Systematic Review
}

\author{
Michelle Bentivegna, MPH, Cassie Hulme, MPH, and Mark H. Ebell, MD, MS
}

Background: The aim of this systematic review is to summarize the best available evidence regarding individual risk factors, simple risk scores, and multivariate models that use patient characteristics, vital signs, comorbidities, and laboratory tests relevant to outpatient and primary care settings.

Methods: Medline, WHO COVID-19, and MedRxIV databases were searched; studies meeting inclusion criteria were reviewed in parallel, and variables describing study characteristics, study quality, and risk factor data were abstracted. Study quality was assessed using the Quality in Prognostic Studies tool. Random effects metaanalysis of relative risks (categorical variables) and unstandardized mean differences (continuous variables) was performed; multivariate models and clinical prediction rules were summarized qualitatively.

Results: A total of 551 studies were identified and 22 studies were included. The median or mean age ranged from 38 to 68 years. All studies included only inpatients, and mortality rates ranged from $3.2 \%$ to $50.5 \%$. Individual risk factors most strongly associated with mortality included increased age, c-reactive protein (CRP), d-dimer, heart rate, respiratory rate, lactate dehydrogenase, and procalcitonin as well as decreased oxygen saturation, the presence of dyspnea, and comorbid coronary heart and chronic kidney disease. Independent predictors of adverse outcomes reported most frequently by multivariate models include increasing age, increased CRP, decreased lymphocyte count, increased lactate dehydrogenase, elevated temperature, and the presence of any comorbidity. Simple risk scores and multivariate models have been proposed but are often complex, and most have not been validated.

Conclusions: Our systematic review identifies several risk factors for adverse outcomes in COVID19-infected inpatients that are often available in the outpatient and primary care settings: increasing age, increased CRP or procalcitonin, decreased lymphocyte count, decreased oxygen saturation, dyspnea on presentation, and the presence of comorbidities. Future research to develop clinical prediction models and rules should include these predictors as part of their core data set to develop and validate pragmatic outpatient risk scores. (J Am Board Fam Med 2021;34:S113-S126.)

Keywords: C-Reactive Protein, Clinical Prediction Rule, Comorbidity, CoVID-19, Prognosis, Risk Factors, Systematic Review, Meta-Analysis

\section{Introduction}

In December 2019, the first cases of novel coronavirus disease, later to become known as COVID-

This article was externally peer reviewed.

Submitted 12 August 2020; revised 22 October 2020; accepted 28 October 2020.

From the Department of Epidemiology and Biostatistics, College of Public Health, University of Georgia ( $\mathrm{MB}, \mathrm{CH}$, MHE).

Funding: None.

Conflict of interest: None.

Contributions of authors: The study was conceived and designed by $\mathrm{MHE}$; $\mathrm{CH}$ and $\mathrm{MB}$ performed the search and summarized the data, supervised by MHE; initial analysis and interpretation of the data were done by $\mathrm{CH}$ and $\mathrm{MB}$, supervised by MHE; manuscript was drafted by MHE, critical revision of the manuscript for important intellectual content by $\mathrm{MB}$ and $\mathrm{CH}$.

Corresponding author: Mark H. Ebell, MD, MS, 125 B. S. Miller Hall (Health Science Campus), Department of Epidemiology and
19, were reported. ${ }^{1}$ Since this outbreak, the world has found itself facing a pandemic with total global cases exceeding 11 million as of October $21,2020,{ }^{2}$ including more than 8 million confirmed cases in the United States. ${ }^{3}$ Symptoms of COVID-19 include cough, fever, dyspnea, chills, myalgias, and loss of taste and smell. However, many individuals remain asymptomatic or have mild symptoms and do not seek testing, so the number of total cases is estimated to be approximately 10 times higher than the number of confirmed cases. ${ }^{4,5}$ Currently the treatment is primarily supportive for patients with nonsevere

Biostatistics, College of Public Health, University of Georgia, Athens, GA 30602 (E-mail: ebell@uga.edu). 
illness, ${ }^{6}$ with respiratory support, remdesivir, and dexamethasone for more severely ill patients. ${ }^{7,8}$

COVID-19 has an infection mortality ratio estimated to be approximately $0.5-1.0 \%,{ }^{9}$ and an accurate prognosis is important to help clinicians decide on the most appropriate site of care (hospital vs home) and the intensity of follow-up and monitoring for both inpatients and outpatients. However, our understanding of clinical risk factors and biomarkers that increase the likelihood of serious illness or death remains incomplete and in some cases is contradictory. Previous studies have found that risk factors for severe illness or mortality include increasing age, male sex, and comorbidities such as diabetes, renal failure, asthma, chronic obstructive pulmonary disease, hypertension and cardiovascular disease. ${ }^{10} \mathrm{~A}$ variety of biomarkers have also been reported to be associated with severe disease or mortality including c-reactive protein (CRP), lactate dehydrogenase (LDH), imaging findings, and the white blood cell count parameters. ${ }^{11}$

However, some of these biomarkers or imaging studies are not rapidly or widely available in outpatient settings, and physicians are increasingly having to make decisions via telehealth or in outpatient clinics. Whereas the availability of tests varies in different countries and in different outpatient settings (urgent care vs primary care vs telehealth vs emergency department), tests like the complete blood count, c-reactive protein (CRP), d-dimer, and procalcitonin are increasingly available. ${ }^{12-15}$ The goal of this systematic review and meta-analysis is to summarize the best available evidence regarding individual risk factors, simple risk scores, and multivariate models that use patient characteristics, vital signs, comorbidities, and laboratory tests in inpatients, as a guide to testing their predictive utility in outpatient and primary care settings.

\section{Methods}

This systematic review was registered with the PROSPERO registry, registration number CRD42020193336. It was declared not human subjects research by the University of Georgia Institutional Review Board.

\section{Inclusion Criteria}

Risk factors were limited to demographics, vital signs, oxygen saturation, comorbidities, and laboratory tests judged to be available in at least some outpatient settings (white blood cell count and differential, c-reactive protein, d-dimer and procalcitonin). Studies were included that reported the association between at least 1 of these risk factors and at least 1 marker of serious illness in cohorts of adults with a confirmed diagnosis of COVID-19. Adverse outcomes for all patients were defined as death, intensive care unit (ICU) stay, or need for mechanical ventilation. Included studies also had to report sufficient data for calculation of relative risk, including the number of patients with and without the risk factor for both good and bad outcomes.

Studies were excluded if they enrolled cohorts of only children. They were also excluded if the study focused on a specialized population such as pregnant women, individuals with cancer, HIV-positive individuals, or postoperative patients. Studies that included less than 50 patients were also excluded from the meta-analysis. There were no limitations set on the country or language of the publications. Studies from preprint servers were also included.

\section{Search Strategy}

A search of the Medline database was used with multiple terms for COVID-19 such as "betacoronavirus," "coronavirus," "COVID-19", and "SARSCoV-2" as well as terms for prognostic studies such as "risk factor," "validation," "prediction rule," and "prognosis." All terms were linked by Boolean terms and the search is shown in Appendix A. The limits "has abstract" and "human" were applied to the search. In addition, the WHO COVID-19 Database and the MedRxIV preprint server were searched to identify additional published and preprint studies using similar keywords.

\section{Data Abstraction}

All abstracts were reviewed for inclusion by the lead author (MHE) and at least 1 other coauthor. For any abstract that was of interest, the full article was obtained and reviewed by the lead author and at least 1 other coauthor. Studies meeting inclusion criteria were reviewed in parallel and variables describing study characteristics, study quality, and risk factor data were abstracted. Risk factor data included the number of individuals with and without the risk factor and how many observed the outcome of interest. We included continuous and categorical data. All discrepancies were discussed and resolved by consensus. If a study reported a simple risk score, clinical 
Figure 1. PRISMA flow diagram of the search process.

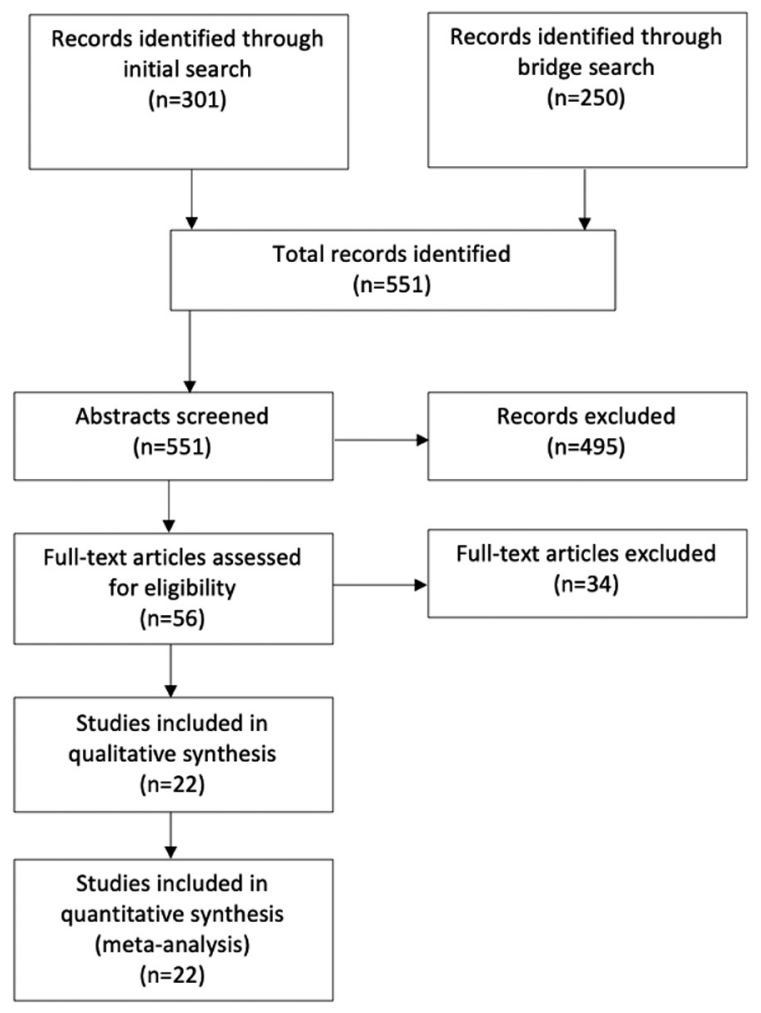

prediction rule, or multivariate model, data regarding them was abstracted separately.

\section{Data Preparation}

Similar risk factors (eg, lymphocyte count $<0.8$ and $<1.0)$ were grouped where it was felt to be clinically reasonable by the lead investigator, a physician. Outcomes were similarly grouped into 3 outcome categories: (1) death, (2) severe disease (intensive care unit admission, mechanical ventilation, or disease progression), and (3) severe disease or death. Where different units were reported, results were converted to a common set of units (eg, milligrams per liter for c-reactive protein). Original risk factors and outcome categories are available for the full data set and are available on request from the investigators.

In studies that did not report mean and standard deviation of continuous variables, these values were estimated using median and interquartile range. The mean was approximated by adding the lower $\left(\mathrm{q}_{1}\right)$ and upper bound $\left(\mathrm{q}_{3}\right)$ to the median $(\mathrm{m})$ and dividing but the constant of 3 . The standard deviation was estimated by subtracting $\mathrm{q}_{1}$ from $\mathrm{q}_{3}$ dividing by $\eta(\mathrm{n})$, which was determined using the sample size and

Table 2 in the publication by Wan et al. ${ }^{16}$ These values were calculated with the equation, $\eta(\mathrm{n})=2 E$ $\left(Z_{(3 \mathrm{Q}+1)}\right)$ for $\mathrm{Q} \leq 50$, using the statistical software $\mathrm{R}$. In cases in which the sample size was large and $Q$ was $\geq 50,1.35$ was used as the $\eta(\mathrm{n})$.

\section{Assessment of Study Quality}

The Quality in Prognostic Studies (QUIPS) ${ }^{17}$ tool was adapted and used to determine the quality of included studies. Definitions of low, moderate, and high risk of bias were prespecified for each domain. The full adapted tool is included in Appendix C. Quality was assessed in parallel by at least 2 researchers and all discrepancies were discussed and resolved by consensus.

\section{Analytic Strategy}

Data were imported into STATA (version 15.1; College Station, TX) and the metan procedure was used to perform the random effects meta-analysis of relative risks (categorical variables) and unstandardized mean differences (continuous variables). Forest plots were created for each risk factor, stratified by outcome (eg, death, severe disease). The number of studies and patients for each summary 
Table 1. Characteristics of Included Studies

\begin{tabular}{|c|c|c|c|c|c|c|}
\hline Author, Year & Country & Patients Studied & $\begin{array}{l}\text { Mean or } \\
\text { median age }\end{array}$ & $\%$ Male & Definition of Bad Outcome & $\begin{array}{c}\text { Mortality } \\
\text { Rate, \% }\end{array}$ \\
\hline $\mathrm{Yu}, 2020^{32}$ & China & $\begin{array}{l}\text { Adults with COVID-19 } \\
\text { from } 27 \text { hospitals in } \\
\text { Jiangsu Province with a } \\
\text { CT scan }\end{array}$ & 48 (median) & 53.0 & $\begin{array}{l}\text { Composite of ICU } \\
\text { admission, acute } \\
\text { respiratory failure } \\
\text { occurrence, or shock } \\
\text { during hospitalization }\end{array}$ & 15.0 \\
\hline Wang, $2020^{33}$ & China & $\begin{array}{l}\text { Adults with COVID-19 who } \\
\text { were discharged from } 2 \\
\text { hospitals (Wuhan and } \\
\text { Hubei Province) }\end{array}$ & 51 (median) & 53.3 & Death & 17.8 \\
\hline Chen, $2020^{34}$ & China & $\begin{array}{l}\text { Adults with COVID-19 } \\
\text { classified as moderately, } \\
\text { severely or critically ill in } \\
1 \text { hospital in Wuhan }\end{array}$ & 68 (median) & 62.4 & Death & 41.2 \\
\hline Zhou, $2020^{35}$ & China & $\begin{array}{l}\text { Adults with COVID-19 who } \\
\text { had been discharged or } \\
\text { died in } 2 \text { Wuhan hospitals }\end{array}$ & 56 (median) & 62.3 & Death & 28.0 \\
\hline Liu, $2020^{36}$ & China & $\begin{array}{l}\text { Adults with COVID-19 } \\
\text { pneumonia in } 3 \text { tertiary } \\
\text { hospitals in Wuhan }\end{array}$ & 38 (median) & 50 & Clinical deterioration & 14.1 \\
\hline Liang, $2020^{19}$ & China & $\begin{array}{l}\text { Adults with COVID-19 } \\
\text { from } 575 \text { hospitals in } 31 \\
\text { regions of China }\end{array}$ & 48.9 (mean) & 57.3 & $\begin{array}{l}\text { Composite of admission to } \\
\text { ICU, invasive ventilation, } \\
\text { death }\end{array}$ & 3.2 \\
\hline Xie, $2020^{37}$ & China & $\begin{array}{l}\text { Adults with COVID-19 who } \\
\text { had been discharged from } \\
\text { or died in } 2 \text { hospitals in } \\
\text { Wuhan }\end{array}$ & 62 (median) & 53.8 & Death & 50.5 \\
\hline Yan, $2020^{38}$ & China & $\begin{array}{l}\text { Adults with COVID-19 in } 1 \\
\text { hospital in Wuhan }\end{array}$ & 58.83 (mean) & 58.7 & Death & 46.4 \\
\hline Cao, $2020^{39}$ & China & $\begin{array}{l}\text { Adults with COVID-19 in } 1 \\
\text { hospital in Shanghai }\end{array}$ & 50.1 (mean) & 51 & Admission to ICU & NR \\
\hline $\mathrm{Hu}, 2020^{40}$ & China & $\begin{array}{l}\text { Adults with COVID-19 in } 1 \\
\text { hospital in Wuhan }\end{array}$ & 61 (median) & 51.4 & Death or progression & 10.8 \\
\hline Luo, $2020^{41}$ & China & $\begin{array}{l}\text { Adults with COVID-19 with } \\
\text { a clinical outcome in } 1 \\
\text { hospital in Wuhan }\end{array}$ & 57 (median) & 50.3 & Death & 28.2 \\
\hline Petrilli, $2020^{42}$ & United States & $\begin{array}{l}\text { Adults with laboratory } \\
\text { confirmed critical } \\
\text { COVID-19 in } 1 \text { hospital } \\
\text { in New York City }\end{array}$ & 54 (median) & 49.5 & $\begin{array}{l}\text { Composite of ICU, } \\
\text { mechanical ventilation, } \\
\text { discharge to hospice or } \\
\text { death. }\end{array}$ & 24.3 \\
\hline $\mathrm{Wu}, 2020^{43}$ & China & $\begin{array}{l}\text { Adults with COVID-19 } \\
\text { pneumonia in } 1 \text { hospital in } \\
\text { Wuhan }\end{array}$ & 51 (median) & 63.7 & ARDS & 21.9 \\
\hline $\mathrm{Li}, 2020^{44}$ & China & $\begin{array}{l}\text { Adults with laboratory } \\
\text { confirmed severe COVID- } \\
19 \text { infection }\end{array}$ & 57 (median) & 58 & Death & 14.7 \\
\hline Jang, $2020^{45}$ & Korea & $\begin{array}{l}\text { Adults with COVID-19 } \\
\text { hospitalized at a tertiary } \\
\text { hospital in Daegu, Korea }\end{array}$ & 56.9 (mean) & 43.6 & $\begin{array}{l}\text { Compositive of ARDS, ICU } \\
\text { care, or death }\end{array}$ & 7.3 \\
\hline $\mathrm{Xu}, 2020^{46}$ & China & $\begin{array}{l}\text { Adults with laboratory- } \\
\text { confirmed COVID-19 } \\
\text { admitted to } 16 \text { tertiary } \\
\text { hospitals from } 8 \text { provinces } \\
\text { in China }\end{array}$ & 46.1 (mean) & 54 & $\begin{array}{l}\text { Composite of death, ICU, or } \\
\text { requiring mechanical } \\
\text { ventilation. }\end{array}$ & 4.7 \\
\hline Zhou, $2020^{47}$ & China & $\begin{array}{l}\text { Adults with laboratory- } \\
\text { confirmed COVID-19 } \\
\text { collected from } 47 \\
\text { locations in Sichaun }\end{array}$ & 43 (median) & 56.6 & $\begin{array}{l}\text { Vasopressors or respiratory } \\
\text { failure }+3 \text { of: respiratory } \\
\text { rate }>30, \mathrm{PaO}_{2} / \mathrm{FIO}_{2} \leq 250 \\
\text { mm } \mathrm{Hg}, \text { infiltrates, } \\
\text { confusion, BUN } \geq 20 \mathrm{mg} / \\
\text { dL, leukopenia, } \\
\text { hypothermia, }\end{array}$ & NR \\
\hline
\end{tabular}




\begin{tabular}{|c|c|c|c|c|c|c|}
\hline Author, Year & Country & Patients Studied & $\begin{array}{l}\text { Mean or } \\
\text { median age }\end{array}$ & $\%$ Male & Definition of Bad Outcome & $\begin{array}{c}\text { Mortality } \\
\text { Rate, \% }\end{array}$ \\
\hline & & & & & $\begin{array}{l}\text { thrombocytopenia, or } \\
\text { hypotension. }\end{array}$ & \\
\hline Hou, $2020^{48}$ & China & $\begin{array}{l}\text { Adults with laboratory- } \\
\text { confirmed COVID-19 } \\
\text { hospitalized at Beijing } \\
\text { hospitals }\end{array}$ & 50.9 (median) & 43.6 & $\begin{array}{l}\text { Progression defined as } \\
\text { having a clinically } \\
\text { advanced type of COVID- } \\
\text { 19, ICU admission, or } \\
\text { death during } \\
\text { hospitalization }\end{array}$ & 5.0 \\
\hline Zhang, $2020^{49}$ & China & $\begin{array}{l}\text { Adults with laboratory- } \\
\text { confirmed COVID-19 in } \\
1 \text { hospital in Wuhan, } \\
\text { China }\end{array}$ & 38.0 (median) & 41.4 & $\begin{array}{l}\text { Disease deterioration } \\
\text { including the transfer to } \\
\text { ICU and death }\end{array}$ & 13.5 \\
\hline Liu, $2020^{50}$ & China & $\begin{array}{l}\text { Adults with laboratory- } \\
\text { confirmed COVID-19 in } \\
1 \text { hospital in Wuhan, } \\
\text { China }\end{array}$ & 65.5 (median) & 35.0 & $\begin{array}{l}\text { Severe disease defined as } \\
\text { having shortness of breath, } \\
\mathrm{RR} \geq 30 \mathrm{bpm}, \mathrm{O}_{2} \\
\text { sat } \leq 93 \%, \mathrm{PaO}_{2} / \\
\mathrm{FIO}_{2} \leq 300 \mathrm{~mm} \mathrm{Hg} \text {, and } \\
\text { progression on imaging }\end{array}$ & NR \\
\hline Zhu, $2020^{51}$ & China & $\begin{array}{l}\text { Adults with confirmed } \\
\text { COVID-19 at } 1 \text { hospital } \\
\text { in Zhejiang, China }\end{array}$ & 50.9 (mean) & 35.4 & $\begin{array}{l}\text { Severe disease defined as } \\
\text { shortness of breath, RR } \\
\geq 30 \text { bpm, } \mathrm{O}_{2} \text { sat } \leq 93 \%, \\
\mathrm{PaO}_{2} / \mathrm{FIO} \mathrm{O}_{2} \leq 300 \mathrm{~mm} \mathrm{Hg}, \\
\text { or lesion progression }\end{array}$ & NR \\
\hline $\mathrm{Hu}, 2020^{52}$ & China & $\begin{array}{l}\text { Adults with laboratory- } \\
\text { confirmed critical } \\
\text { COVID-19 in } 1 \text { hospital } \\
\text { in Wuhan, China }\end{array}$ & 60.8 (mean) & 50.9 & Death & 18.0 \\
\hline
\end{tabular}

COVID-19, coronavirus 2019; CT, computed tomography; RR, respiratory rate; $\mathrm{O}_{2}$ sat, oxygen saturation; BUN, blood urea nitrogen; ICU, intensive care unit; ARDS, acute respiratory distress syndrome.

estimate were also noted. To perform random effects meta-analysis of continuous variables, median and interquartile ranges were converted to estimates of mean and standard deviation before calculation using the method of Wan et al. ${ }^{16}$

\section{Results}

A summary of our search process is outlined in Figure 1. Our initial search of PubMed was performed in May 2020, and a bridge search was performed on June 30, 2020. A total of 551 records were identified, and 56 full-text articles were screened for inclusion. Ultimately, 22 studies were included in the quantitative synthesis.

The characteristics of included studies are summarized in Table 1. One study was set in the United States, 1 in Korea, and the remainder were set in China. All studies included adult inpatients with previously confirmed COVID-19 and reported outcomes of death, severe disease, or both; there were no studies of outpatient prognosis. The median or mean age ranged from 38 to 68 years with the majority of the participants being male in 16 of 22 studies. Mortality rates ranged from $3.2 \%$ to $50.5 \%$.

Study quality was assessed for all included studies using the QUIPS tool. All 22 studies were considered to have moderate risk of bias for study participation because only inpatients were included, limiting generalizability to patients cared for outside the hospital. Eight studies included patients who were still hospitalized at the time of data collection and were therefore considered to have high risk of bias for study attrition and ascertainment of the final outcome. Three studies did not provide a multivariate analysis and were considered to have high risk of bias for study confounding. All results and analytic strategies seemed to be clearly reported and were not considered to be a source of bias. Detailed results of the quality assessment including the adapted QUIPS tool are shown in Appendix C.

Table 2 includes summary estimates of the relative risks and their corresponding confidence intervals for each categorical risk factor reported by at least 3 studies using the same cutoff for abnormality (full data are available in Appendix B). Risk factors 
Table 2. Association between Categorical Variables and Mortality or Severe Disease in Patients with CovID-19

\begin{tabular}{|c|c|c|c|}
\hline Variables & Studies & Total Patients & RR (95\% CI) \\
\hline \multicolumn{4}{|l|}{ Outcome $=$ death } \\
\hline \multicolumn{4}{|l|}{ Demographics and vital signs } \\
\hline Oxygen saturation $<90 \%$ to $93 \%$ & 3 & 718 & $6.07(4.27-8.63)$ \\
\hline Respiratory rate $>20$ to 30 breaths $/ \mathrm{min}$ & 4 & 841 & $3.80(2.13-6.78)$ \\
\hline Age $\geq 60$ to 65 years & 3 & 483 & $2.62(1.91-3.58)$ \\
\hline Male sex & 9 & 2213 & $1.24(1.08-1.43)$ \\
\hline \multicolumn{4}{|l|}{ Comorbidities } \\
\hline Coronary heart disease & 9 & 2213 & $5.27(2.89-9.58)$ \\
\hline Chronic kidney disease & 5 & 1562 & $5.11(2.18-12.0)$ \\
\hline Chronic obstructive pulmonary disease & 9 & 2213 & $3.79(2.51-5.72)$ \\
\hline Hypertension & 9 & 2213 & $2.34(1.80-3.05)$ \\
\hline Diabetes mellitus & 9 & 2213 & $2.15(1.46-3.15)$ \\
\hline \multicolumn{4}{|l|}{ Symptoms } \\
\hline Dyspnea & 3 & 1073 & $3.47(1.67-7.18)$ \\
\hline Fever & 6 & 1530 & $1.10(0.95-1.28)$ \\
\hline Cough & 5 & 1366 & $1.02(0.93-1.13)$ \\
\hline \multicolumn{4}{|l|}{ Laboratory tests } \\
\hline Procalcitonin $\geq 0.25$ to $0.5 \mathrm{ng} / \mathrm{mL}$ & 4 & 728 & $9.59(3.71-24.8)$ \\
\hline Increased LDH & 3 & 831 & $5.16(0.72-37.09)$ \\
\hline $\mathrm{D}$-dimer $\geq 1.0 \mathrm{mg} / \mathrm{L}$ & 4 & 718 & $2.56(2.10-3.13)$ \\
\hline D-dimer $\geq 0.5 \mathrm{mg} / \mathrm{L}$ & 3 & 569 & $1.54(1.32-1.80)$ \\
\hline D-dimer $0.5-1.0 \mathrm{mg} / \mathrm{L}$ & 4 & 718 & $0.45(0.31-0.64)$ \\
\hline $\mathrm{D}$-dimer $\leq 0.5 \mathrm{mg} / \mathrm{L}$ & 4 & 718 & $0.19(0.12-0.30)$ \\
\hline Lymphocyte count $<0.8$ to $1.1 \times 109 / \mathrm{mL}$ & 4 & 841 & $2.07(1.51-2.84)$ \\
\hline $\mathrm{WBC} \geq 4 \times 109 / \mathrm{mL}$ & 3 & 567 & $1.07(0.81-1.41)$ \\
\hline $\mathrm{WBC}<3.5-4 \times 109 / \mathrm{mL}$ & 3 & 567 & $0.34(0.20-0.56)$ \\
\hline WBC 4 to $10 \times 109 / \mathrm{mL}$ & 3 & 567 & $0.65(0.54-0.78)$ \\
\hline \multicolumn{4}{|l|}{ Outcome $=$ severe disease } \\
\hline Male sex & 11 & 4582 & $1.30(1.11-1.53)$ \\
\hline \multicolumn{4}{|l|}{ Comorbidities } \\
\hline Coronary heart disease & 9 & 4364 & $3.69(1.75-7.77)$ \\
\hline Chronic kidney disease & 3 & 3516 & $3.02(0.63-14.6)$ \\
\hline Diabetes mellitus & 11 & 4582 & $2.57(1.59-4.17)$ \\
\hline Chronic obstructive pulmonary disease & 7 & 1033 & $2.47(1.34-4.52)$ \\
\hline Hypertension & 11 & 4582 & $2.29(1.61-3.26)$ \\
\hline \multicolumn{4}{|l|}{ Symptoms } \\
\hline Dyspnea & 7 & 1473 & $6.28(3.10-12.7)$ \\
\hline Fever & 10 & 4504 & $1.13(1.05-1.22)$ \\
\hline Cough & 9 & 1775 & $1.11(0.87-1.42)$ \\
\hline \multicolumn{4}{|l|}{ Laboratory tests } \\
\hline Procalcitonin $>0.05 \mathrm{ng} / \mathrm{mL}$ & 3 & 448 & $4.06(0.65-25.3)$ \\
\hline C-reactive protein $>5$ to $0 \mathrm{mg} / \mathrm{L}$ & 3 & 448 & $1.68(1.47-1.93)$ \\
\hline
\end{tabular}

Variables reported by fewer than 3 studies are not included but can be found online.

$\mathrm{RR}$, risk ratio; CI, confidence interval.

most strongly associated with mortality included increased procalcitonin, increased $\mathrm{LDH}$, decreased oxygen saturation, the presence of dyspnea, comorbid coronary heart disease, chronic obstructive pulmonary disease and chronic kidney disease, and increased respiratory rate. Risk factors reported by at least 3 studies and most strongly associated with the outcome severe disease included the presence of dyspnea, elevated procalcitonin, and comorbid chronic heart disease and chronic kidney disease. 
Table 3. Weighted Mean Differences between Patients With and Without the Outcome

\begin{tabular}{|c|c|c|c|}
\hline Risk Factor & Studies & Patients & WMD (95\% CI) \\
\hline \multicolumn{4}{|l|}{ Outcome $=$ death } \\
\hline $\mathrm{CRP}(\mathrm{mg} / \mathrm{L})$ & 4 & 1016 & $40.4(27.4-53.3)$ \\
\hline Age (years) & 7 & 1418 & $18.5(15.4-21.6)$ \\
\hline D-dimer (mg/L) & 4 & 870 & $7.8(6.1-9.4)$ \\
\hline Heart rate (beats/minute) & 3 & 486 & $5.3(1.7-8.9)$ \\
\hline Neutrophil count $\left(\times 10^{9} / \mathrm{mL}\right)$ & 3 & 679 & $4.3(2.7-5.8)$ \\
\hline WBC count $\left(\times 10^{9} / \mathrm{mL}\right)$ & 6 & 1314 & $4.0(3.4-4.6)$ \\
\hline Respiratory rate & 3 & 486 & $3.1(1.5-4.7)$ \\
\hline Procalcitonin (ng/mL) & 3 & 763 & $0.34(0.27-0.40)$ \\
\hline Oxygen saturation (\%) & 4 & 823 & $-8.9(-11.9$ to -5.9$)$ \\
\hline Lymphocyte count $\left(\times 10^{9} / \mathrm{mL}\right)$ & 6 & 1314 & $-0.41(-0.50$ to -0.32$)$ \\
\hline \multicolumn{4}{|l|}{ Outcome $=$ severe disease } \\
\hline CRP (mg/L) & 4 & 731 & $34.2(15.4-53.1)$ \\
\hline Age (years) & 8 & 2223 & $14.1(10.9-17.6)$ \\
\hline Neutrophil count $\left(\times 10^{9} / \mathrm{mL}\right)$ & 5 & 752 & $0.94(-0.42$ to -2.3$)$ \\
\hline WBC count $\left(\times 10^{9} / \mathrm{mL}\right)$ & 5 & 954 & $0.73(-0.63$ to 2.1$)$ \\
\hline D-dimer (mg/L) & 5 & 604 & $0.30(0.06-0.55)$ \\
\hline Lymphocyte count $\left(\times 10^{9} / \mathrm{mL}\right)$ & 5 & 948 & $-0.44(-0.52$ to -0.36$)$ \\
\hline \multicolumn{4}{|l|}{ Outcome $=$ severe disease or death } \\
\hline $\mathrm{CRP}(\mathrm{mg} / \mathrm{L})$ & 4 & 4531 & $60.5(47.9-73.2)$ \\
\hline Age (years) & 5 & 4641 & $15.9(10.4-21.3)$ \\
\hline Neutrophil count $\left(\times 10^{9} / \mathrm{mL}\right)$ & 4 & 1912 & $2.6(2.1-3.2)$ \\
\hline WBC count $\left(\times 10^{9} / \mathrm{mL}\right)$ & 3 & 322 & $2.0(0.98-3.0)$ \\
\hline Procalcitonin (ng/mL) & 3 & 4420 & $0.13(-0.30$ to 0.56$)$ \\
\hline Oxygen saturation (\%) & 3 & 2940 & $-4.4(-7.3$ to -1.4$)$ \\
\hline Lymphocyte count & 5 & 4641 & $-0.63(-1.0$ to -0.22$)$ \\
\hline
\end{tabular}

Variables reported by fewer than 3 studies are not included but can be found in the online Appendix B.

WMD, weighted mean differences; WBC, white blood count; CRP, c-reactive protein.

Cough and fever were not significantly associated with any of our adverse outcomes with relative risks for all risk categories near the null. Increased white blood cell count and increased neutrophil count were most strongly associated with the outcome severe disease or death (data not shown; no risk factor for this outcome was reported by more than 2 studies).

Risk factors reported as continuous variables are summarized in Table 3, showing the unstandardized weighted mean difference between patients with and without the risk factor for each risk factor. For the outcome of death, risk factors with clinically and statistically significant differences between patients dying and survivors included higher CRP, age, $\mathrm{d}$-dimer, and white blood cell parameters as well as lower oxygen saturation and lymphocyte count. Risk factors that that had significantly higher values in patients with the outcome of severe disease or death included CRP, age, neutrophil count, and white blood cell count; oxygen saturation and lymphocyte count were significantly lower. For the outcome of severe disease, CRP and age were significantly higher, whereas lymphocyte count was significantly lower. Whereas d-dimer was higher, the difference was small and not clinically important. Forest plots for categorical variables are summarized in online Appendix D, and for continuous variables in online Appendix E.

Table 4 summarizes risk factors identified as independent predictors of adverse outcomes by multivariate models reported in 17 studies. Risk factors most often included in multivariate models included increasing age, increased CRP, decreased lymphocyte count, increased $\mathrm{LDH}$, elevated temperature, and the presence of any comorbidity.

Finally, Table 5 summarizes 11 clinical prediction rules reported in the literature to date. They used a variety of approaches, including risk scores, classification trees, full models in the form of online calculators, and nomograms. Only 4 of the clinical prediction rules have been externally validated, ${ }^{18,19}$ and only 2 have been externally validated outside China ( 1 in the United Kingdom and 1 in France). ${ }^{20,21}$ 


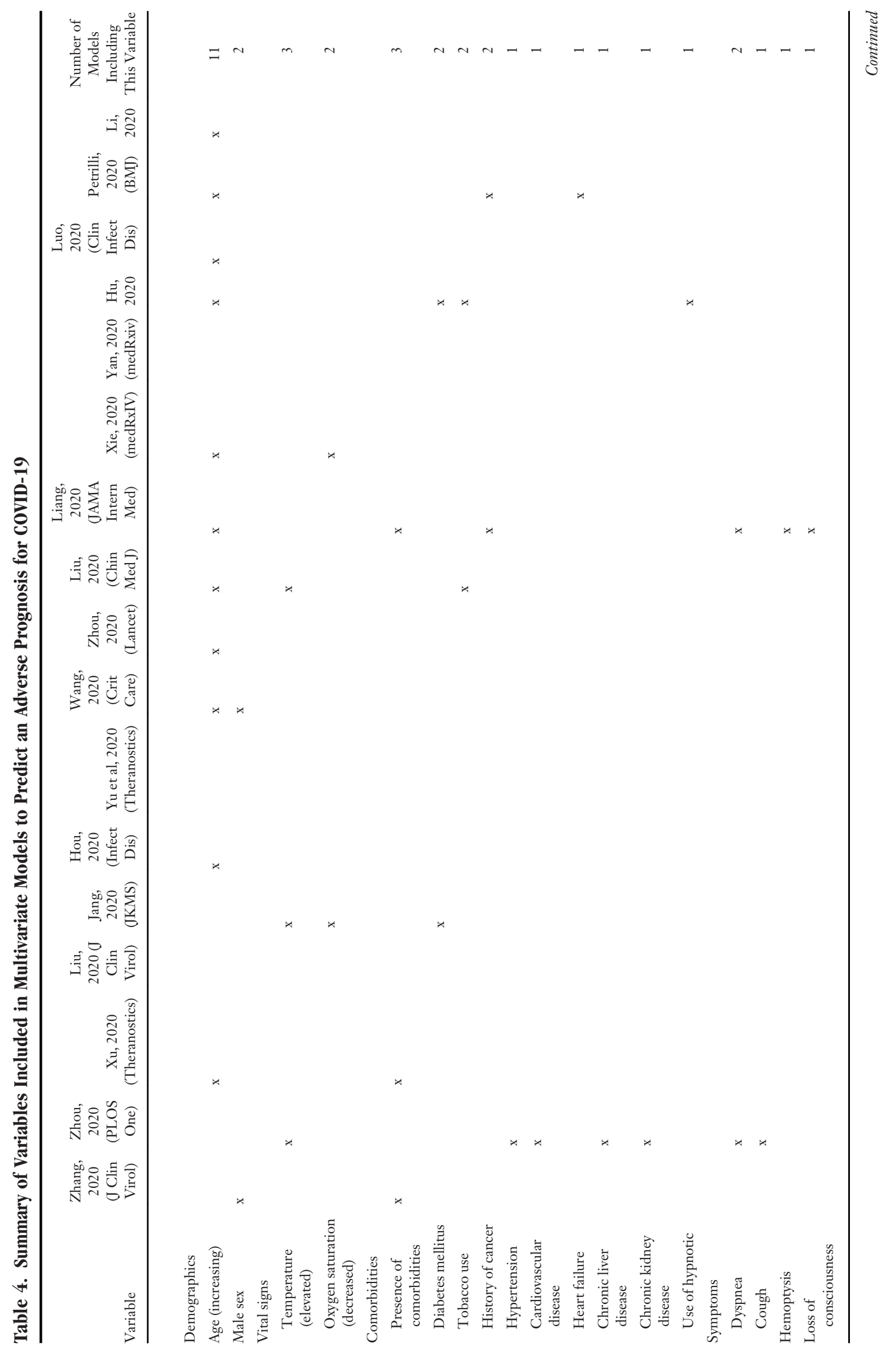




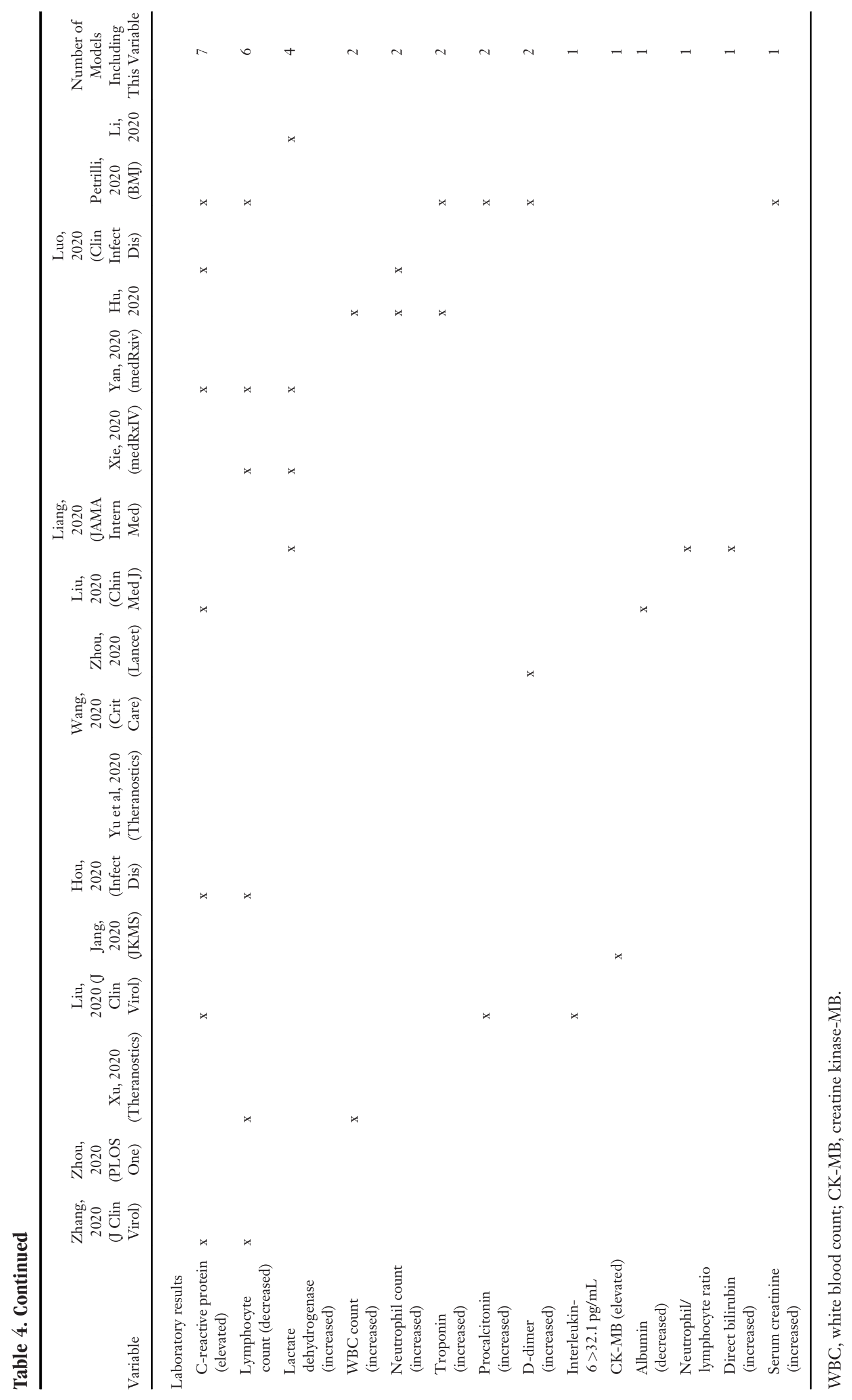


Table 5. Proposed Clinical Prediction Rules in the Medical Literature

\begin{tabular}{|c|c|c|c|c|}
\hline Study & Predictor Variables & $\begin{array}{l}\text { Outcome } \\
\text { Predicted }\end{array}$ & Validation (Country) & $\begin{array}{l}\text { Type of CPR With } \\
\text { Outcome }\end{array}$ \\
\hline $\mathrm{Lu}, 2020^{*}$ & Age, CRP & Death & $\begin{array}{l}\text { Internal validation } \\
\quad \text { (China) }\end{array}$ & $\begin{array}{l}\text { Classification tree: } \\
\text { Low: } 0 \% \text { mortality } \\
\text { Mod: } 6 \% \text { mortality } \\
\text { High: } 33 \% \text { mortality }\end{array}$ \\
\hline Xie, 2020 & Age, LDH, lymphocytes, SpO2 & Death & $\begin{array}{l}\text { External validation in } 1 \\
\text { hospital (China) }\end{array}$ & $\begin{array}{l}\text { Probability assessment using } \\
\text { full logistic model as } \\
\text { nomogram }\end{array}$ \\
\hline Yan, 2020 & LDH, CRP, lymphocytes & Death & $\begin{array}{l}\text { Internal validation } \\
\text { (China) }\end{array}$ & Classification tree \\
\hline $\mathrm{Yu}, 2020$ & $\begin{array}{l}\text { Age, sex, diabetes mellitus, } \\
\text { lymphocytes, procalcitonin }\end{array}$ & Death & $\begin{array}{l}\text { Internal validation } \\
\quad \text { (China) }\end{array}$ & $\begin{array}{l}\text { Risk score } \\
\text { High risk ( }>3 \text { points): } 22.8 \% \\
\text { Low risk ( } \leq 3 \text { points): } 5.4 \% \text { ) }\end{array}$ \\
\hline Shi, 2020 & Age, sex, hypertension & $\begin{array}{l}\text { Death or severe } \\
\text { disease }\end{array}$ & $\begin{array}{l}\text { Internal validation } \\
\text { (China) }\end{array}$ & $\begin{array}{l}0 \text { factors: } 0 \% \\
1 \text { factor: } 6 \% \\
2 \text { factors: } 19 \% \\
3 \text { factors: } 40 \%\end{array}$ \\
\hline Galloway, 2020 & $\begin{array}{l}\text { Age, sex, race, oxygen saturation, } \\
\text { chest radiograph, neutrophils, } \\
\text { CRP, albumin, creatinine, diabetes } \\
\text { mellitus, hypertension, chronic } \\
\text { lung disease }\end{array}$ & $\begin{array}{l}\text { Death or critical } \\
\text { care }\end{array}$ & $\begin{array}{l}\text { Internal validation } \\
\text { (UK) }\end{array}$ & $\begin{array}{l}\text { Risk score } \\
\text { High risk ( } \geq 4 \text { points): } 40.7 \% \\
\text { Low risk ( }<4 \text { points): } 12.4 \%\end{array}$ \\
\hline Petrilli, 2020 & $\begin{array}{l}\text { Age, } \mathrm{SpO}_{2} \text {, procalcitonin, troponin, } \\
\text { CRP, hypertension }\end{array}$ & Severe disease & Internal validation (US) & Classification tree \\
\hline Liang, 2020 & $\begin{array}{l}\text { Age, neutrophil/lymphocyte ratio, } \\
\text { LDH, direct bilirubin, chest } \\
\text { radiograph, hemoptysis, dyspnea, } \\
\text { unconsciousness, comorbidities, } \\
\text { cancer }\end{array}$ & Severe disease & $\begin{array}{l}\text { External validation in } 3 \\
\text { hospitals (China) }\end{array}$ & $\begin{array}{l}\text { Logistic regression model } \\
\text { requiring online calculator }\end{array}$ \\
\hline Zhou, 2020 & $\begin{array}{l}\text { Temperature, cough, dyspnea, } \\
\text { hypertension, chronic liver disease, } \\
\text { chronic kidney disease, } \\
\text { cardiovascular disease }\end{array}$ & Severe disease & $\begin{array}{l}\text { Internal validation } \\
\quad \text { (China) }\end{array}$ & Nomogram \\
\hline Kaeuffer, $2020^{20}$ & $\begin{array}{l}\text { Age, BMI, sex, dyspnea, neutrophil } \\
\text { count, lymphocyte count, CRP }\end{array}$ & Severe disease & External validation & $\begin{array}{l}\text { Risk score: } \\
\text { Low risk }(\leq 6): 13 \% \\
\text { Moderate risk }(6-14): \mathrm{NR} \\
\text { High risk }(>14): 66 \%\end{array}$ \\
\hline Knight, $2020^{21}$ & $\begin{array}{l}\text { Age, sex, number of comorbidities, } \\
\text { respiratory rate, } \mathrm{SpO}_{2} \text {, level of } \\
\text { consciousness, urea level, CRP }\end{array}$ & Mortality & External validation & $\begin{array}{l}\text { Risk score from } 0 \text { to } 21 \\
\quad \text { points } \\
\text { Low risk }(0-3): 1.2 \% \\
\text { Intermediate risk (4-8): } \\
\quad 9.9 \% \\
\text { High risk (9-14): } 31.4 \% \\
\text { Very high risk }(\geq 15): 61.5 \%\end{array}$ \\
\hline
\end{tabular}

*Study included some patients with suspected but not confirmed COVID-19. Preprint at MedRxIV: Lu J, et al. ACP risk grade: a simple mortality index for patients with confirmed or suspected severe acute respiratory syndrome coronavirus 2 disease (COVID19) during the early stage of outbreak in Wuhan (https://doi.org/10.1101/2020.02.20.20025510).

$\mathrm{CPR}$, clinical prediction rule; CRP, c-reactive protein; LDH, lactate dehydrogenase; BMI, body mass index. 


\section{Discussion}

We have summarized the literature to date with regard to prognosis of inpatients with COVID-19, with a focus on clinical factors and tests that may be available in the outpatient or primary care setting during the initial evaluation of a patient with COVID-19. Thus, we did not abstract data regarding imaging studies or tests that are not widely available such as interleukin-6, LDH, or serum albumin. Our systematic review identified several risk factors that are consistently and strongly associated with adverse outcomes based on univariate and multivariate analyses: increasing age, increased CRP, LDH, or procalcitonin, decreased lymphocyte count, decreased oxygen saturation, dyspnea on presentation, and the presence of comorbidities. Fever and cough were not strongly associated with severe disease or mortality, perhaps because almost all hospitalized patients had these symptoms, making them less helpful for discrimination. Future research to study prognosis in the North America and Europe and develop prediction models and clinical prediction rules should include these predictors as part of their core data set. Whereas the data are limited in several ways as noted below, they represent the best evidence currently available. Greater availability of tests like CRP, d-dimer, and procalcitonin at the point of care is desired by physicians and would facilitate more efficient evaluation of patients for COVID-19 and other important conditions such as community-acquired pneumonia. ${ }^{13,22,23}$ Similarly, providing inexpensive oxygen saturation monitors to outpatients at risk for deterioration should be encouraged based on our findings.

\section{Limitations}

The studies that we identified had a number of important limitations that should be addressed by future research. These limitations can inform design of future studies of prognosis and risk models in North America and Europe. First, studies had variable definitions of serious illness. Standardization would assist in future analyses, although there is inherent subjectivity and between country variability in decisions to move a patient to the intensive care unit. The World Health Organization has identified 6 clinical severity categories for patients with COVID-19: (1) not hospitalized; (2) hospitalized, not requiring supplemental oxygen; (3) hospitalized, requiring supplemental oxygen; (4) hospitalized requiring nasal high-flow oxygen, noninvasive mechanical ventilation, or both; (5) hospitalized, requiring invasive mechanical ventilation, extracorporeal membrane oxygenation or both; and (6) death. ${ }^{24}$ For outpatients and patients being evaluated in primary care, the important clinical prediction is category 1 versus 2 or higher or possibly 1 or 2 versus 3 or higher. All the studies in our metaanalysis included only hospitalized patients, and in some cases excluded patients who had not yet died or been discharged. There was also a wide range in mortality rates, which likely reflects differences in health systems, hospital capacity, and the decision to admit as well as declining case fatality rates as treatments emerge. In addition, timing of data collection was not always clearly reported, and in 8 of 22 studies, outcome ascertainment was incomplete. Future studies should also include patients managed in the outpatient setting to identify risk factors for deterioration and later hospitalization as well as patients who are hospitalized. As the literature evolves, additional risk factors may also be identified such as red cell distribution width. ${ }^{25}$

Another limitation of the current literature is that many of the multivariate models and clinical prediction rules were quite complex, in some cases including 9-12 predictors including imaging. ${ }^{19,26}$ They also often required laboratory tests such as $\mathrm{LDH}$, interleukin-6, and serum albumin that are not readily or rapidly available in outpatient settings. This places a high data collection and computational burden for those hoping to apply these tools in practice. We encourage researchers to create simpler clinical prediction rules and to provide online calculators. ${ }^{19}$ The most widely used clinical prediction rules in current clinical practice such as the Ottawa Ankle Rules, ${ }^{27}$ the Strep Score, ${ }^{28,29}$ the CURB-65 (Confusion, Urea nitrogen, Respiratory rate, Blood pressure, and 65 years) ${ }^{30}$ and the CRB- $65^{31}$ require only 4 or 5 pieces of clinical information. This reduces the implementation burden and facilitates memorization. In addition, because many patients are initially evaluated in the outpatient or even telehealth settings, clinical prediction rules that require few or no laboratory tests are needed. Fourth, most of the clinical prediction rules have not been externally validated. Before implementation, clinical prediction rules require at a minimum internal validation using bootstrapping or split sample approaches, and ideally should be externally validated in a different population. 
Finally, It is important that clinical prediction rules identify risk groups that are situated in the clinical context with an understanding of clinical decision making. For example, the risk score proposed by Galloway et $\mathrm{al}^{26}$ identifies a low-risk group with $12.4 \%$ mortality and a high-risk group with $40.7 \%$ mortality. Most physicians and their patients would consider both groups to be above the risk threshold for hospitalization. Similarly, Yu et $\mathrm{al}^{32}$ identify a low-risk group with $5.4 \%$ mortality and a high-risk group with $22.8 \%$ mortality. What would be more helpful was a clinical prediction rule that identified 3 or more risk groups, with the lowest-risk group clearly below the threshold for hospitalization, a moderate-risk group that might be followed closely as an outpatient with oxygen saturation monitoring or that might be hospitalized, and a high-risk group that would generally be hospitalized. More work is needed to determine these risk thresholds.

In conclusion, we have comprehensively reviewed the literature on risk factors for severe disease and mortality in COVID-19 and found it lacking. Whereas this represents the best available evidence, studies to date have been in hospitalized patients; prognostic studies are needed in the outpatient setting in which most patients are managed. Our research provides a starting point for outpatient studies, identifying several clinical variables and laboratory tests that are promising for predicting severe disease and mortality. There is a need for pragmatic clinical prediction rules with a low burden of data collection to identify patients who are at low, moderate, or high risk for severe disease or death to guide decision making in the outpatient and primary care settings. In addition, as more data are published in both inpatient and outpatient settings, it will also be important to update systematic reviews like this one. Because of their usefulness in determining prognosis, tests such as c-reactive protein, d-dimer, and procalcitonin should be made available and studied in outpatient settings, and home monitoring of oxygen saturation should be offered to identify patients at risk for a poor outcome.

To see this article online, please go to: http://jabfm.org/content/ 34/Supplement/S113.full.

\section{References}

1. Yi Y, Lagniton PNP, Ye S, Li E, Xu R-H. COVID-19: what has been learned and to be learned about the novel coronavirus disease. Int $\mathrm{J}$ Biol Sci 2020;16:1753-66.

2. World Health Organization. Coronavirus Disease (COVID-19) Situation Report-127. World Health Organization.

3. Centers for Disease Control and Prevention. Cases in the U.S.|CDC. https://www.cdc.gov/coronavirus/ 2019-ncov/cases-updates/cases-in-us.html.

4. Stringhini S, Wisniak A, Piumatti G, et al. Seroprevalence of anti-SARS-CoV-2 IgG antibodies in Geneva, Switzerland (SEROCoV-POP): a population-based study. Lancet 2020.

5. Havers FP, Reed C, Lim TW. Seroprevalence of antibodies to SARS-CoV-2 in six sites in the United States, March 23-May 3, 2020. medRxiv. org 2020.

6. Centers for Disease Control and Prevention. Interim clinical guidance for management of patients with confirmed 2019-nCoV|CDC. https:// www.cdc.gov/coronavirus/2019-ncov/hcp/clinicalguidance-management-patients.html.

7. Horby P, Lim WS, Emberson J. Effect of dexamethasone in hospitalized patients with COVID19-preliminary report. medRxiv.org 2020.

8. Beigel JH, Tomashek KM, Dodd LE, et al. Remdesivir for the treatment of Covid-19-preliminary report. N Engl J Med 2020;383:1813-26.

9. Ferguson NM, Laydon D, Nedjati-Gilani G, et al. Impact of non-pharmaceutical interventions (NPIs) to reduce COVID-19 mortality and healthcare demand.

10. Xie J, Tong Z, Guan X, Du B, Qiu H, Slutsky AS. Critical care crisis and some recommendations during the COVID-19 epidemic in China. Intensive Care Med 2020;46:837-40.

11. Moutchia J, Pokharel P, Kerri A, et al. Clinical laboratory parameters associated with severe or critical novel coronavirus disease 2019 (COVID-19): a systematic review and meta-analysis. medrxiv.org 2020.

12. Do NT, Ta NT, Tran NT, et al. Point-of-care Creactive protein testing to reduce inappropriate use of antibiotics for non-severe acute respiratory infections in Vietnamese primary health care: a randomised controlled trial. Lancet Glob Heal 2016;4: e633-41-e641.

13. Howick J, Cals JWL, Jones C, et al. Current and future use of point-of-care tests in primary care: an international survey in Australia, Belgium, The Netherlands, the UK and the USA. BMJ Open 2014;4:e05611-e005611.

14. Huang DT, Yealy DM, Filbin MR, et al. Procalcitoninguided use of antibiotics for lower respiratory tract infection. N Engl J Med 2018;379:236-49.

15. Waterfield T, Maney JA, Hanna M, Fairley D, Shields MD. Point-of-care testing for procalcitonin in identifying bacterial infections in young infants: a diagnostic accuracy study. BMC Pediatr 2018;18. 
16. Wan X, Wang W, Liu J, Tong T. Estimating the sample mean and standard deviation from the sample size, median, range and/or interquartile range. BMC Med Res Methodol 2014;14.

17. Hayden JA, van der Windt DA, Cartwright JL, Côté $\mathrm{P}$, Bombardier C. Assessing bias in studies of prognostic factors. Ann Intern Med 2013;158:280-6.

18. Xie J, Hungerford D, Chen H, et al. Development and external validation of a prognostic multivariable model on admission for hospitalized patients with COVID-19. SSRN Electron J 2020.

19. Liang $W$, Liang $\mathrm{H}, \mathrm{Ou} \mathrm{L}$, et al. Development and Validation of a Clinical Risk Score to Predict the Occurrence of Critical Illness in Hospitalized Patients with COVID-19. JAMA Intern Med 2020;180:1081.

20. Kaeuffer C, Ruch Y, et al. The BAS ${ }^{2}$ IC score: a useful tool to identify patients at high risk of early progression to severe COVID-19. Open Forum Infect Dis 2020.

21. Knight SR, Ho A, Pius R, ISARIC4C investigators, et al. Risk stratification of patients admitted to hospital with covid-19 using the ISARIC WHO Clinical Characterisation Protocol: development and validation of the $4 \mathrm{C}$ Mortality Score. BMJ 2020;370:m3339.

22. Cals JWL, Ebell MH. C-reactive protein: Guiding antibiotic prescribing decisions at the point of care. Br J Gen Pract 2018;68:112-3.

23. Hardy V, Thompson M, Keppel GA, et al. Qualitative study of primary care clinicians' views on point-of-care testing for C-reactive protein for acute respiratory tract infections in family medicine. BMJ Open 2017;7:e012503.

24. World Health Organization. R \& D blueprint and COVID-19. World Health Organization-WHO Web Site. https://www.who.int/teams/blueprint/ covid-19.

25. Foy BH, Carlson JCT, Reinertsen E, et al. Association of red blood cell distribution width with mortality risk in hospitalized adults with SARSCoV-2 Infection. JAMA Netw open 2020;3: e2022058.

26. Galloway JB, Norton S, Barker RD, et al. A clinical risk score to identify patients with COVID-19 at high risk of critical care admission or death: an observational cohort study. J Infect 2020.

27. Stiell I. Ottawa ankle rules. Can Fam Physician 1996.

28. Ebell MH, Smith MA, Barry HC, Ives K, Carey M. The rational clinical examination. Does this patient have strep throat? JAMA 2000;284:2912-8. http:// www.ncbi.nlm.nih.gov/pubmed/11147989.

29. Centor RM, Witherspoon JM, Dalton HP, Brody $\mathrm{CE}$, Link K. The diagnosis of strep throat in adults in the emergency room. Med Decis Making 1981;1:239-46.
30. British Thoracic S, Myint PK, Kamath AV, Vowler SL, Maisey DN, Harrison BD, British Thoracic Society. Severity assessment criteria recommended by the British Thoracic Society (BTS) for community-acquired pneumonia (CAP) and older patients. Should SOAR (systolic blood pressure, oxygenation, age and respiratory rate) criteria be used in older people? A compilation of two prospective cohorts. Age Ageing 2006;35:286-91.

31. Ebell MH, Walsh ME, Fahey T, Kearney M, Marchello C. Meta-analysis of calibration, discrimination, and stratum-specific likelihood ratios for the CRB-65 Score. J Gen Intern Med 2019;34:130413.

32. Yu Q, Wang Y, Huang S, et al. Multicenter cohort study demonstrates more consolidation in upper lungs on initial CT increases the risk of adverse clinical outcome in COVID-19 patients. Theranostics 2020;10:5641-8.

33. Wang D, Yin Y, Hu C, et al. Clinical course and outcome of 107 patients infected with the novel coronavirus, SARS-CoV-2, discharged from two hospitals in Wuhan, China. Crit Care 2020;24.

34. Chen T, Wu D, Chen H, et al. Clinical characteristics of 113 deceased patients with coronavirus disease 2019: retrospective study. BMJ 2020;368.

35. Zhou F, Yu T, Du R, et al. Clinical course and risk factors for mortality of adult inpatients with COVID-19 in Wuhan, China: a retrospective cohort study. Lancet 2020.

36. Liu W, Tao ZW, Wang L, et al. Analysis of factors associated with disease outcomes in hospitalized patients with 2019 novel coronavirus disease. Chin Med J (Engl) 2020;133:1032-8.

37. Xie J, Hungerford D, Chen $H$, et al. Development and external validation of a prognostic multivariable model on admission for hospitalized patients with COVID-19. medRxiv April 2020;2020.03.28.20045997.

38. Yan L, Zhang H-T, Xiao Y, et al. Prediction of criticality in patients with severe Covid-19 infection using three clinical features: a machine learningbased prognostic model with clinical data in Wuhan. medRxiv March 2020;2020.02.27.20028027.

39. Cao M, Zhang D, Wang Y, et al. Clinical features of patients infected with the 2019 novel coronavirus (COVID-19) in Shanghai, China. medRxiv 2020;2020.03.04.20030395. March.

40. Hu L, Chen S, Fu Y, et al. Risk factors associated with clinical outcomes in 323 COVID-19 patients in Wuhan, China. medRxiv March 2020;2020.03.25. 20037721.

41. Luo X, Zhou W, Yan X, et al. Prognostic value of C-reactive protein in patients with COVID-19. Clin Infect Dis 2020.

42. Petrilli CM, Jones SA, Yang J, et al. Factors associated with hospital admission and critical illness 
among 5279 people with coronavirus disease 2019 in New York City: Prospective cohort study. BMJ 2020.

43. Wu C, Chen X, Cai Y, et al. Risk factors associated with acute respiratory distress syndrome and death in patients with coronavirus disease 2019 pneumonia in Wuhan, China. JAMA Intern Med 2020;180:934.

44. Li K, Chen D, Chen S, et al. Radiographic findings and other predictors in adults with Covid-19. medRxiv 2020;2:2020.03.23.20041673.

45. Jang JG, Hur J, Choi EY, Hong KS, Lee W, Ahn JH. Prognostic factors for severe coronavirus disease 2019 in Daegu, Korea. J Korean Med Sci 2020;35:e209.

46. Xu PP, Tian RH, Luo S, et al. Risk factors for adverse clinical outcomes with COVID-19 in China: a multicenter, retrospective, observational study. Theranostics 2020;10:6372-83.

47. Zhou Y, He Y, Yang H, et al. Development and validation a nomogram for predicting the risk of severe COVID-19: a multi-center study in Sichuan, China. PLoS One 2020;15:e0233328.
48. Hou $W$, Zhang $W$, Jin R, Liang L, Xu B, Hu Z. Risk factors for disease progression in hospitalized patients with COVID-19: a retrospective cohort study. Infect Dis (Auckl) 2020;52:498-505.

49. Zhang J, Yu M, Tong S, Liu LY, Tang LV. Predictive factors for disease progression in hospitalized patients with coronavirus disease 2019 in Wuhan, China. J Clin Virol 2020;127: 104392 .

50. Liu F, Li L, Xu MD, et al. Prognostic value of interleukin-6, C-reactive protein, and procalcitonin in patients with COVID-19. J Clin Virol 2020; 127:104370.

51. Zhu Z, Cai T, Fan L, et al. Clinical value of immune-inflammatory parameters to assess the severity of coronavirus disease 2019. Int J Infect Dis 2020;95:332-9.

52. Hu H, Yao N, Qiu Y. Comparing rapid scoring systems in mortality prediction of critically ill patients with novel coronavirus disease. Burton JH, ed. Acad Emerg Med 2020;27:461-8. 


\section{Appendices}

\section{Appendix A: Search Strategy}

("betacoronavirus"[mh] OR "coronavirus"[tiab] OR “corona-virus"[tiab] OR "COVID-19"[tiab] OR “COVID19"[tiab] OR “2019-nCoV”[tiab] OR “nCoV”[tiab] OR "SARS-CoV-2"[tiab] OR "SARSCOV2"[tiab] OR "2019-nCov"[tiab] OR "2019 coronavirus"[tiab] OR "novel coronavirus"[tiab]) AND ("risk factor”[tiab] OR "validation"[tiab] OR "prediction rule"[tiab] OR “clinical prediction"[tiab] OR "risk model”[tiab] OR "prediction model"[tiab] OR "prognosis"[tiab] OR "prognostic"[tiab] OR "Predictive value of tests"[mh] OR "prognosis"[mh] OR "prognosis"[mh])

\section{Appendix B: Evaluation of Study Quality Using the Quality of Prognostic Studies Tool}

Table 2. Study Quality Assessment Using the Quality of Prognostic Studies Tool

\begin{tabular}{|c|c|c|c|c|c|c|}
\hline Authors & $\begin{array}{c}\text { Study } \\
\text { Participation }\end{array}$ & $\begin{array}{l}\text { Study } \\
\text { Attrition }\end{array}$ & $\begin{array}{l}\text { Prognostic Factor } \\
\text { Measurement }\end{array}$ & $\begin{array}{c}\text { Outcome } \\
\text { Measurement }\end{array}$ & $\begin{array}{c}\text { Study } \\
\text { Confounding }\end{array}$ & $\begin{array}{l}\text { Statistical Analysis and } \\
\text { Reporting }\end{array}$ \\
\hline Yu et al, 2020 & M & $\mathrm{L}$ & $\mathrm{L}$ & $\mathrm{L}$ & $\mathrm{L}$ & $\mathrm{L}$ \\
\hline Wang, 2020 & M & $\mathrm{L}$ & $\mathrm{L}$ & $\mathrm{L}$ & $\mathrm{L}$ & $\mathrm{L}$ \\
\hline Chen, 2020 & M & $\mathrm{H}$ & $\mathrm{L}$ & $\mathrm{L}$ & $\mathrm{H}$ & $\mathrm{L}$ \\
\hline Zhou, 2020 & M & L & $\mathrm{L}$ & $\mathrm{L}$ & $\mathrm{L}$ & $\mathrm{L}$ \\
\hline Liu, 2020 & M & $\mathrm{L}$ & $\mathrm{L}$ & $\mathrm{L}$ & $\mathrm{L}$ & $\mathrm{L}$ \\
\hline Liang, 2020 & M & $\mathrm{L}$ & $\mathrm{L}$ & $\mathrm{L}$ & $\mathrm{L}$ & $\mathrm{L}$ \\
\hline Xie, 2020 & M & $\mathrm{L}$ & $\mathrm{L}$ & $\mathrm{L}$ & $\mathrm{L}$ & $\mathrm{L}$ \\
\hline Yan, 2020 & M & $\mathrm{H}$ & $\mathrm{L}$ & $\mathrm{L}$ & $\mathrm{L}$ & $\mathrm{L}$ \\
\hline Cao, 2020 & M & $\mathrm{L}$ & $\mathrm{L}$ & $\mathrm{L}$ & $\mathrm{H}$ & $\mathrm{L}$ \\
\hline Нu, 2020 & M & $\mathrm{H}$ & $\mathrm{L}$ & $\mathrm{L}$ & $\mathrm{L}$ & $\mathrm{L}$ \\
\hline Luo, 2020 & M & $\mathrm{L}$ & $\mathrm{L}$ & $\mathrm{L}$ & $\mathrm{L}$ & $\mathrm{L}$ \\
\hline Petrilli, 2020 & M & $\mathrm{H}$ & $\mathrm{L}$ & $\mathrm{L}$ & $\mathrm{L}$ & $\mathrm{L}$ \\
\hline $\mathrm{Wu}, 2020$ & M & $\mathrm{H}$ & $\mathrm{L}$ & $\mathrm{L}$ & $\mathrm{H}$ & $\mathrm{L}$ \\
\hline $\mathrm{Li}, 2020$ & M & $\mathrm{H}$ & $\mathrm{L}$ & $\mathrm{L}$ & $\mathrm{L}$ & $\mathrm{L}$ \\
\hline Jang, 2020 & M & $\mathrm{L}$ & $\mathrm{L}$ & $\mathrm{L}$ & $\mathrm{L}$ & $\mathrm{L}$ \\
\hline $\mathrm{Xu}, 2020$ & M & $\mathrm{H}$ & $\mathrm{L}$ & $\mathrm{L}$ & $\mathrm{L}$ & $\mathrm{L}$ \\
\hline Zhou, 2020 & M & $\mathrm{L}$ & $\mathrm{L}$ & $\mathrm{L}$ & $\mathrm{L}$ & $\mathrm{L}$ \\
\hline Hou, 2020 & M & $\mathrm{L}$ & $\mathrm{L}$ & $\mathrm{L}$ & $\mathrm{L}$ & $\mathrm{L}$ \\
\hline Zhang, 2020 & M & $\mathrm{H}$ & $\mathrm{L}$ & $\mathrm{L}$ & $\mathrm{L}$ & $\mathrm{L}$ \\
\hline Liu, 2020 & M & $\mathrm{L}$ & $\mathrm{L}$ & $\mathrm{L}$ & $\mathrm{L}$ & $\mathrm{L}$ \\
\hline Zhu, 2020 & M & $\mathrm{L}$ & $\mathrm{L}$ & $\mathrm{L}$ & $\mathrm{L}$ & $\mathrm{L}$ \\
\hline $\mathrm{Hu}, 2020$ & M & $\mathrm{L}$ & $\mathrm{L}$ & $\mathrm{L}$ & $\mathrm{L}$ & $\mathrm{L}$ \\
\hline
\end{tabular}

$\mathrm{L}$, low risk of bias; $\mathrm{M}$, moderate risk of bias; $\mathrm{H}$, high risk of bias. 


\begin{tabular}{|c|c|c|c|c|c|c|}
\hline Variables & $\begin{array}{c}\text { Study } \\
\text { Participation }\end{array}$ & Study Attrition & $\begin{array}{c}\text { Prognostic Factor } \\
\text { Measurement }\end{array}$ & $\begin{array}{c}\text { Outcome } \\
\text { Measurement }\end{array}$ & $\begin{array}{c}\text { Study } \\
\text { Confounding }\end{array}$ & $\begin{array}{l}\text { Statistical } \\
\text { Analysis and } \\
\text { Reporting }\end{array}$ \\
\hline $\begin{array}{l}\text { High risk of } \\
\text { bias }\end{array}$ & $\begin{array}{l}\text { Specialized } \\
\text { population (ie, } \\
\text { pregnant, } \\
\text { elderly) or } \\
\text { subset of very } \\
\text { ill patients only }\end{array}$ & $\begin{array}{l}\text { Incomplete } \\
\text { outcome } \\
\text { ascertainment } \\
\text { (some patients } \\
\text { still } \\
\text { hospitalized) }\end{array}$ & $\begin{array}{l}\text { Unclear definition } \\
\text { for prognostic } \\
\text { factors }\end{array}$ & $\begin{array}{l}\text { Outcome not } \\
\text { defined }\end{array}$ & $\begin{array}{l}\text { No multivariate } \\
\text { analysis } \\
\text { performed }\end{array}$ & $\begin{array}{l}\text { Selective } \\
\text { reporting of } \\
\text { results, no } \\
\text { clear analytic } \\
\text { strategy }\end{array}$ \\
\hline $\begin{array}{l}\text { Moderate risk } \\
\text { of bias }\end{array}$ & Only inpatients & $\begin{array}{l}\text { Complete } \\
\text { ascertainment } \\
\text { but }>10 \% \text { loss } \\
\text { to follow-up }\end{array}$ & $\begin{array}{l}\text { Post hoc selection of } \\
\text { cut points }\end{array}$ & $\begin{array}{l}\text { Unclear } \\
\text { definition }\end{array}$ & & \\
\hline $\begin{array}{l}\text { Low risk of } \\
\text { bias }\end{array}$ & $\begin{array}{l}\text { Inpatient and } \\
\text { outpatient }\end{array}$ & $\begin{array}{l}\text { Complete } \\
\text { ascertainment } \\
\text { and }<10 \% \text { loss } \\
\text { to follow-up }\end{array}$ & $\begin{array}{l}\text { Typical cutoffs used, } \\
\text { clearly defined }\end{array}$ & $\begin{array}{l}\text { Clear and } \\
\text { reproducible } \\
\text { definition }\end{array}$ & $\begin{array}{l}\text { Multivariate } \\
\text { analysis } \\
\text { reported }\end{array}$ & $\begin{array}{l}\text { Full reporting, } \\
\text { analytic } \\
\text { strategy } \\
\text { clearly } \\
\text { described }\end{array}$ \\
\hline
\end{tabular}

\section{Appendix C: Full Data Set}

Association between categorical variables and mortality, severe disease, or both in patients with CoVID-19

\begin{tabular}{|c|c|c|c|}
\hline Risk Factor & Studies & Patients & RR (95\% CI) \\
\hline \multicolumn{4}{|l|}{ Outcome $=$ Death } \\
\hline Age $<39$ to 40 years & 1 & 274 & $0.01(0.00-0.21)$ \\
\hline Age $<45$ years & 1 & 107 & $0.21(0.06-0.79)$ \\
\hline Age $>45$ years & 1 & 107 & $1.79(1.38-2.32)$ \\
\hline Age $>75$ years & 1 & 107 & $10.42(3.58-30.33)$ \\
\hline Age $\geq 40$ years & 1 & 274 & $1.49(1.33-1.66)$ \\
\hline Age $\geq 60$ to 65 years & 3 & 483 & $2.62(1.91-3.58)$ \\
\hline Age $40-60$ years & 1 & 274 & $0.55(0.34-0.89)$ \\
\hline Age $45-59$ years & 1 & 107 & $0.19(0.03-1.34)$ \\
\hline Age $60-75$ years & 1 & 107 & $2.03(0.97-4.23)$ \\
\hline Any comorbidity & 1 & 692 & $2.99(2.37-3.77)$ \\
\hline Chronic kidney disease & 5 & 1562 & $5.11(2.18-11.98)$ \\
\hline COPD & 9 & 2213 & $3.79(2.51-5.72)$ \\
\hline Coronary heart disease & 9 & 2213 & $5.27(2.89-9.58)$ \\
\hline Cough & 5 & 1366 & $1.02(0.93-1.13)$ \\
\hline $\mathrm{CRP}>100 \mathrm{mg} / \mathrm{L}$ & 2 & 243 & $4.16(2.71-6.37)$ \\
\hline $\mathrm{CRP} \geq 3 \mathrm{mg} / \mathrm{L}$ & 1 & 102 & $1.19(1.04-1.36)$ \\
\hline CRP increased & 1 & 581 & $1.42(1.29-1.55)$ \\
\hline $\mathrm{D}$-dimer $\leq 0.5 \mathrm{mg} / \mathrm{L}$ & 4 & 718 & $0.19(0.12-0.30)$ \\
\hline D-dimer $>21 \mathrm{mg} / \mathrm{L}$ & 1 & 247 & $17.53(5.54-55.49)$ \\
\hline D-dimer $\geq 0.5 \mathrm{mg} / \mathrm{L}$ & 3 & 569 & $1.54(1.32-1.80)$ \\
\hline D-dimer $\geq 1.0 \mathrm{mg} / \mathrm{L}$ & 4 & 718 & $2.56(2.10-3.13)$ \\
\hline D-dimer $0.5-1.0 \mathrm{mg} / \mathrm{L}$ & 4 & 718 & $0.45(0.31-0.64)$ \\
\hline D-dimer increased & 1 & 371 & $2.63(1.91-3.63)$ \\
\hline Diabetes mellitus & 9 & 2213 & $2.15(1.46-3.15)$ \\
\hline Dyspnea & 3 & 1073 & $3.47(1.67-7.18)$ \\
\hline Fever & 6 & 1530 & $1.10(0.95-1.28)$ \\
\hline Heart rate $>100$ & 1 & 274 & $1.66(1.23-2.25)$ \\
\hline
\end{tabular}

Continued 


\begin{tabular}{|c|c|c|c|}
\hline Risk Factor & Studies & Patients & RR $(95 \% \mathrm{CI})$ \\
\hline Heart rate $\geq 125$ & 1 & 191 & $12.55(0.61-257.13)$ \\
\hline Hypertension & 9 & 2213 & $2.34(1.80-3.05)$ \\
\hline LDH increased & 3 & 831 & $5.16(0.72-37.09)$ \\
\hline Lymphocyte count $<0.5$ & 1 & 274 & $7.84(3.84-16.00)$ \\
\hline Lymphocyte count $<0.8$ to 1.1 & 4 & 841 & $2.07(1.51-2.84)$ \\
\hline Lymphocyte count $\geq 1$ & 1 & 274 & $0.17(0.09-0.31)$ \\
\hline Lymphocyte count $0.5-0.8$ & 1 & 274 & $1.53(1.07-2.19)$ \\
\hline Lymphocyte count $0.8-1$ & 1 & 274 & $0.81(0.46-1.43)$ \\
\hline Lymphocytes decreased & 1 & 547 & $2.10(1.87-2.36)$ \\
\hline Male sex & 9 & 2213 & $1.24(1.08-1.43)$ \\
\hline Neutrophil count $>6.3$ & 1 & 274 & $6.29(3.94-10.04)$ \\
\hline Neutrophils increased & 1 & 544 & $6.12(3.86-9.70)$ \\
\hline Oxygen saturation $<90$ to 93 & 3 & 718 & $6.07(4.27-8.63)$ \\
\hline Procalcitonin $<0.05 \mathrm{ng} / \mathrm{mL}$ & 1 & 236 & $0.02(0.00-0.15)$ \\
\hline Procalcitonin $<0.1 \mathrm{ng} / \mathrm{mL}$ & 1 & 164 & $0.44(0.31-0.64)$ \\
\hline Procalcitonin $>0.05 \mathrm{ng} / \mathrm{mL}$ & 1 & 102 & $1.79(1.45-2.22)$ \\
\hline Procalcitonin $\geq 0.1$ to $0.25 \mathrm{ng} / \mathrm{mL}$ & 1 & 164 & $2.53(1.34-4.79)$ \\
\hline Procalcitonin $\geq 0.25$ to $0.5 \mathrm{ng} / \mathrm{mL}$ & 4 & 728 & $9.59(3.71-24.82)$ \\
\hline Procalcitonin $\geq 2.0 \mathrm{ng} / \mathrm{mL}$ & 1 & 236 & $24.71(1.44-423.13)$ \\
\hline Procalcitonin $0.05-0.5 \mathrm{ng} / \mathrm{mL}$ & 1 & 236 & $1.31(1.04-1.65)$ \\
\hline Procalcitonin $0.5-2.0 \mathrm{ng} / \mathrm{mL}$ & 1 & 236 & $13.13(4.10-42.04)$ \\
\hline Procalcitonin increased & 1 & 455 & $1.48(1.18-1.85)$ \\
\hline Respiratory rate $<24$ & 1 & 274 & $0.48(0.38-0.60)$ \\
\hline Respiratory rate $>20$ to 30 & 4 & 841 & $3.80(2.13-6.78)$ \\
\hline Respiratory rate $24-30$ & 1 & 274 & $3.02(1.79-5.10)$ \\
\hline $\mathrm{SBP}<90 \mathrm{~mm} \mathrm{Hg}$ & 2 & 274 & $5.70(1.23-26.34)$ \\
\hline $\mathrm{SBP} \geq 140 \mathrm{~mm} \mathrm{Hg}$ & 1 & 274 & $2.16(1.49-3.12)$ \\
\hline SBP $90-140 \mathrm{~mm} \mathrm{Hg}$ & 1 & 274 & $0.62(0.51-0.76)$ \\
\hline Troponin $>34.2$ & 1 & 101 & $6.96(2.61-17.17)$ \\
\hline $\mathrm{WBC}<3.5$ to 4 & 3 & 567 & $0.34(0.20-0.56)$ \\
\hline$W B C \geq 4$ & 3 & 567 & $1.07(0.81-1.41)$ \\
\hline$W B C \geq 9.5$ to 10 & 3 & 567 & $5.73(2.48-13.27)$ \\
\hline WBC 4-10 & 3 & 567 & $0.65(0.54-0.78)$ \\
\hline WBC increased & 1 & 630 & $16.08(9.05-28.58)$ \\
\hline \multicolumn{4}{|l|}{ Outcome $=$ severe disease or death } \\
\hline Age $\geq 40$ years & 1 & 323 & $1.13(1.07-1.19)$ \\
\hline Age $\geq 60$ to 65 years & 1 & 323 & $2.06(1.56-2.74)$ \\
\hline Chronic kidney disease & 1 & 1590 & $4.45(1.76-11.29)$ \\
\hline COPD & 2 & 1913 & $5.63(1.07-29.69)$ \\
\hline Coronary heart disease & 1 & 1590 & $3.15(1.75-5.57)$ \\
\hline Cough & 2 & 1821 & $1.06(0.96-1.17)$ \\
\hline $\mathrm{CRP} \geq 3 \mathrm{mg} / \mathrm{L}$ & 1 & 306 & $1.13(1.07-1.19)$ \\
\hline Diabetes mellitus & 2 & 1913 & $3.24(2.41-4.36)$ \\
\hline Dyspnea & 2 & 1717 & $3.09(2.59-3.68)$ \\
\hline Fever & 2 & 1859 & $1.01(0.96-1.07)$ \\
\hline Hypertension & 2 & 1913 & $2.00(1.06-3.78)$ \\
\hline LDH increased & 1 & 87 & $3.32(1.75-6.32)$ \\
\hline Lymphocyte count $<2.0$ & 1 & 305 & $1.57(1.33-1.84)$ \\
\hline Male sex & 2 & 1901 & $1.19(1.06-1.33)$ \\
\hline
\end{tabular}




\begin{tabular}{|c|c|c|c|}
\hline Risk Factor & Studies & Patients & RR (95\% CI) \\
\hline Neutrophil count $>7.5$ & 1 & 305 & $3.02(2.28-3.99)$ \\
\hline$W B C \geq 9.5$ to 10 & 1 & 305 & $9.14(3.94-21.24)$ \\
\hline \multicolumn{4}{|l|}{ Outcome $=$ severe disease } \\
\hline Age $<39$ to 40 years & 1 & 198 & $0.29(0.08-1.11)$ \\
\hline Age $>75$ years & 1 & 2729 & $1.69(1.49-1.93)$ \\
\hline Age $\geq 40$ years & 1 & 198 & $1.39(1.15-1.68)$ \\
\hline Age $\geq 50$ years & 1 & 198 & $1.62(1.23-2.14)$ \\
\hline Age $\geq 60$ to 65 years & 2 & 564 & $2.53(1.89-3.40)$ \\
\hline Age $\geq 70$ years & 1 & 198 & $4.71(2.33-9.53)$ \\
\hline Age $40-49$ years & 1 & 198 & $0.67(0.17-2.61)$ \\
\hline Age $50-59$ years & 1 & 198 & $0.13(0.01-2.11)$ \\
\hline Age $60-69$ years & 1 & 198 & $1.74(0.90-3.33)$ \\
\hline Asthma or COPD & 1 & 2729 & $1.05(0.88-1.24)$ \\
\hline Chronic kidney disease & 3 & 3516 & $3.02(0.63-14.60)$ \\
\hline COPD & 7 & 1033 & $2.47(1.34-4.52)$ \\
\hline Coronary heart disease & 9 & 4364 & $3.69(1.75-7.77)$ \\
\hline Cough & 9 & 1775 & $1.11(0.87-1.42)$ \\
\hline $\mathrm{CRP}>5$ to $10 \mathrm{mg} / \mathrm{L}$ & 3 & 448 & $1.68(1.47-1.93)$ \\
\hline $\mathrm{D}$-dimer $\geq 0.5 \mathrm{mg} / \mathrm{L}$ & 2 & 877 & $3.10(1.45-6.64)$ \\
\hline Diabetes mellitus & 11 & 4582 & $2.57(1.59-4.17)$ \\
\hline spnea & 7 & 1473 & $6.28(3.10-12.74)$ \\
\hline Fever & 10 & 4504 & $1.13(1.05-1.22)$ \\
\hline Heart rate $\geq 90$ & 1 & 366 & $0.88(0.43-1.79)$ \\
\hline Hypertension & 11 & 4582 & $2.29(1.61-3.26)$ \\
\hline LDH increased & 1 & 110 & $2.65(1.93-3.63)$ \\
\hline Lymphocyte count $<0.8$ to 1.1 & 2 & 308 & $27.36(0.96-778.27)$ \\
\hline Lymphocyte count $>3.2$ & 1 & 198 & $0.13(0.02-0.90)$ \\
\hline Male sex & 11 & 4582 & $1.30(1.11-1.53)$ \\
\hline Neutrophil count $<1.8$ & 1 & 198 & $0.26(0.02-4.12)$ \\
\hline Neutrophil count $>6.3$ & 1 & 308 & $4.13(2.31-7.37)$ \\
\hline Oxygen saturation $<88$ & 1 & 2729 & $3.69(3.06-4.46)$ \\
\hline Oxygen saturation $<96$ & 1 & 366 & $1.39(0.77-2.52)$ \\
\hline Procalcitonin $>0.05 \mathrm{ng} / \mathrm{mL}$ & 3 & 448 & $4.06(0.65-25.29)$ \\
\hline Respiratory rate $>20$ to 30 & 2 & 477 & $2.11(0.20-22.05)$ \\
\hline $\mathrm{SBP} \geq 110 \mathrm{~mm} \mathrm{Hg}$ & 1 & 366 & $1.07(1.01-1.13)$ \\
\hline WBC $<3.5$ to 4 & 1 & 198 & $0.67(0.17-2.61)$ \\
\hline$W B C \geq 9.5$ to 10 & 2 & 308 & $5.52(2.41-12.66)$ \\
\hline
\end{tabular}

$\mathrm{COPD}=$ chronic obstructive pulmonary disease; RR, risk ratio; CI, confidence interval; CRP, c-reactive protein; LDH, lactate dehydrogenase; WBC, white blood count; SBP, systolic blood pressure. 


\begin{tabular}{|c|c|c|c|}
\hline Risk Factor & Studies & Patients & WMD (95\% CI) \\
\hline \multicolumn{4}{|l|}{ Outcome $=$ death } \\
\hline Age & 7 & 1418 & $18.5(15.4-21.6)$ \\
\hline Systolic blood pressure & 1 & 105 & $12.5(0.64-24.3)$ \\
\hline Mean arterial pressure & 2 & 381 & $8.0(4.3-11.8)$ \\
\hline D-dimer (mg/L) & 4 & 870 & $7.6(6.1-9.4)$ \\
\hline Heart rate & 3 & 486 & $5.3(1.7-8.9)$ \\
\hline $\mathrm{CRP}(\mathrm{mg} / \mathrm{L})$ & 4 & 1016 & $40.4(27.4-53.3)$ \\
\hline Neutrophil count & 3 & 679 & $4.3(2.7-5.8)$ \\
\hline WBC count & 6 & 1314 & $4.0(3.4-4.6)$ \\
\hline Respiratory rate & 3 & 486 & $3.1(1.5-4.7)$ \\
\hline Procalcitonin & 3 & 763 & $0.34(0.27-0.40)$ \\
\hline Oxygen saturation & 4 & 823 & $-8.9(-11.9$ to -5.9$)$ \\
\hline Lymphocyte count & 6 & 1314 & $-0.4(-0.5$ to -0.3$)$ \\
\hline \multicolumn{4}{|c|}{ Outcome $=$ severe disease or death } \\
\hline CRP (mg/L) & 4 & 4531 & $60.5(47.9-73.2)$ \\
\hline Age & 5 & 4641 & $15.9(10.4-21.3)$ \\
\hline Systolic blood pressure & 1 & 110 & $8.6(0.07-17.1)$ \\
\hline Neutrophil count & 4 & 1912 & $2.6(2.1-3.2)$ \\
\hline WBC count & 3 & 322 & $2.0(0.98-3.0)$ \\
\hline Respiratory rate & 2 & 211 & $1.5(0.02-3.3)$ \\
\hline Heart rate & 2 & 211 & $0.99(-3.7,5.5)$ \\
\hline D-dimer (mg/L) & 1 & 2729 & $0.31(0.27-0.36)$ \\
\hline Procalcitonin & 3 & 4420 & $0.13(-0.30$ to 0.56$)$ \\
\hline Mean arterial pressure & 1 & 101 & $-6.1(-17.8$ to 5.6$)$ \\
\hline Oxygen saturation & 3 & 2940 & $-4.4(-7.3$ to -1.4$)$ \\
\hline Lymphocyte count & 5 & 4641 & $-0.63(-1.0$ to -0.22$)$ \\
\hline \multicolumn{4}{|c|}{ Outcome $=$ severe disease } \\
\hline $\mathrm{CRP}(\mathrm{mg} / \mathrm{L})$ & 4 & 731 & $34.2(15.4-53.1)$ \\
\hline Age & 8 & 2223 & $14.1(10.9-17.6)$ \\
\hline Oxygen saturation & 1 & 78 & $12.3(2.6-22.1)$ \\
\hline Heart rate & 1 & 78 & $7.3(-21.4$ to -36.0$)$ \\
\hline Neutrophil count & 5 & 752 & $0.94(-0.42$ to 2.3$)$ \\
\hline WBC count & 5 & 954 & $0.73(-0.63$ to 2.1$)$ \\
\hline D-dimer $(\mathrm{mg} / \mathrm{L})$ & 5 & 604 & $0.30(0.06-0.55)$ \\
\hline Procalcitonin & 2 & 276 & $0.05(-0.08$ to 0.19$)$ \\
\hline Respiratory rate & 1 & 78 & $0.00(-15.6$ to 15.6$)$ \\
\hline Lymphocyte count & 5 & 948 & $-0.44(-0.52$ to -0.36$)$ \\
\hline
\end{tabular}

WMD, weighted mean differences; COPD = chronic obstructive pulmonary disease; CI, confidence interval; CRP, c-reactive protein; LDH, lactate dehydrogenase; WBC, white blood count; SBP, systolic blood pressure. 
Appendix D. Forest Plots (Full List) for Categorical Variables

Age 40-49 years

Study

Events, Events, \%

ID

$\mathrm{RR}(95 \% \mathrm{Cl}) \quad$ Trestment Contral Weight

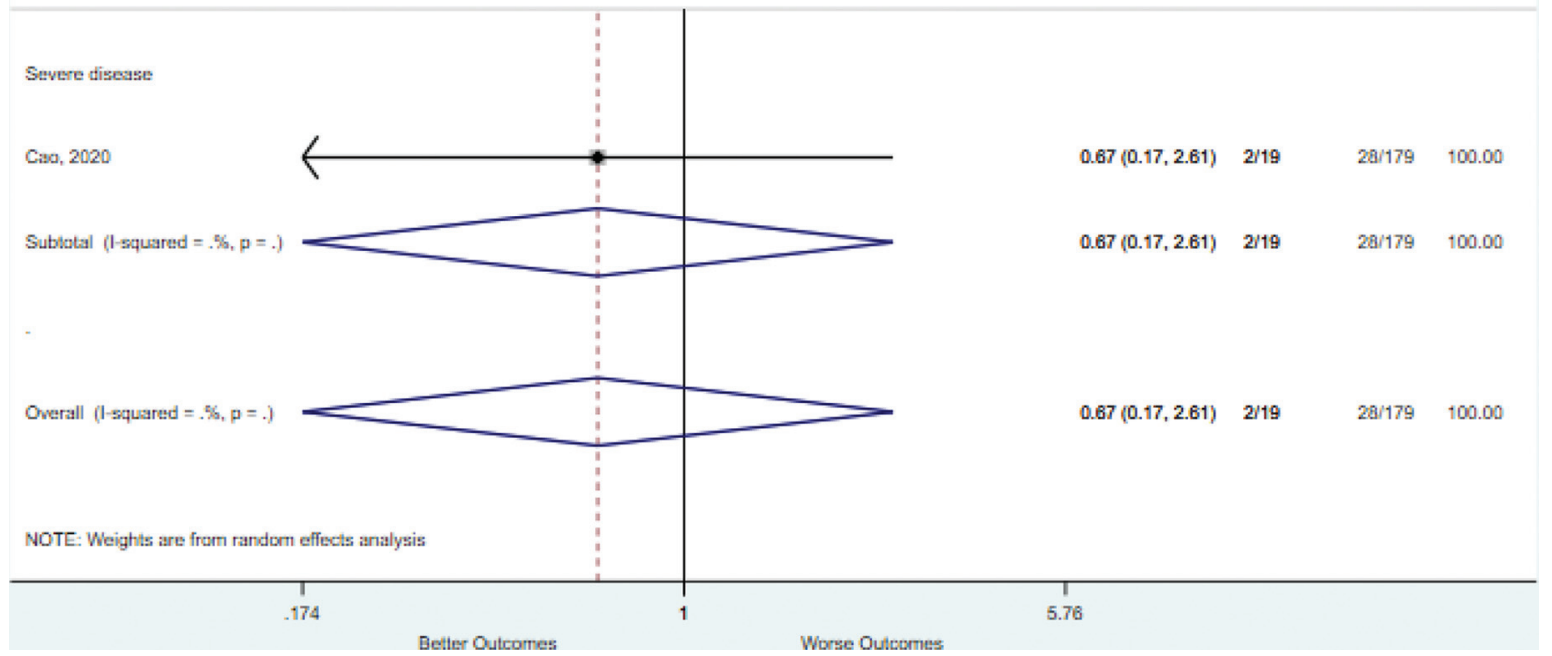

Age 40-60 years

Study

ID

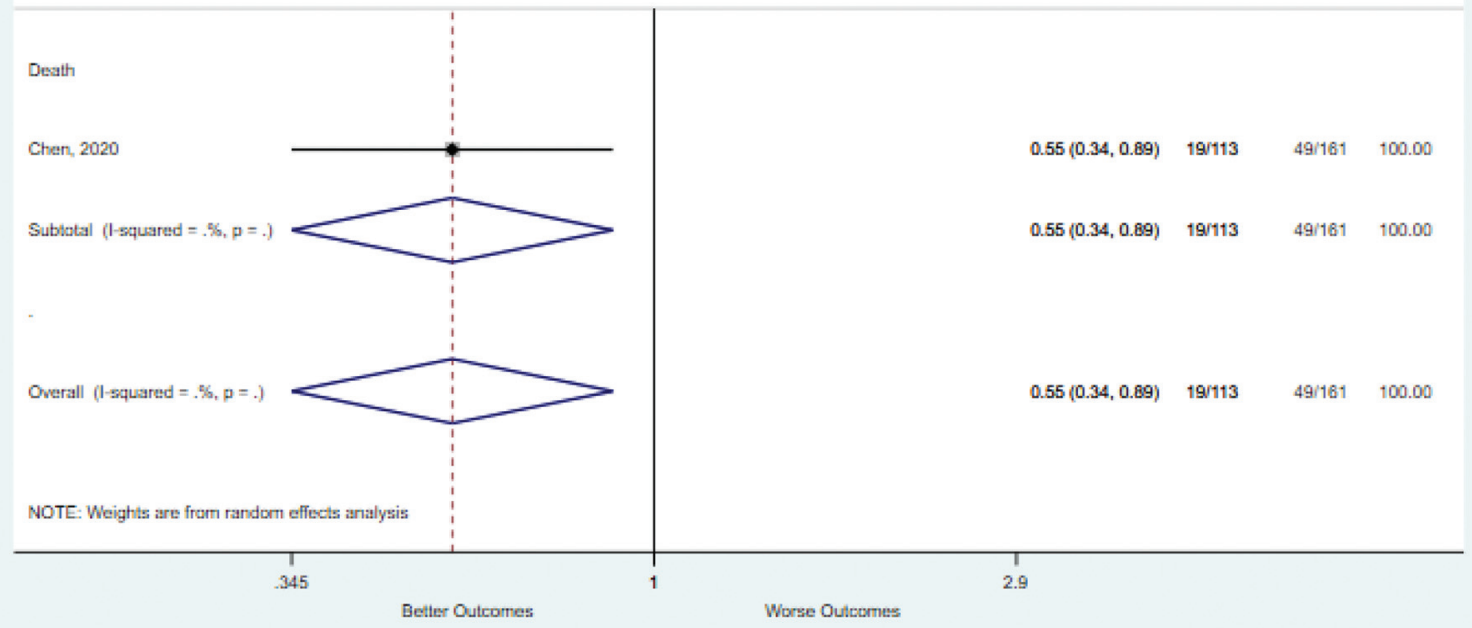


Age 45-59 years

Age 50-59 years

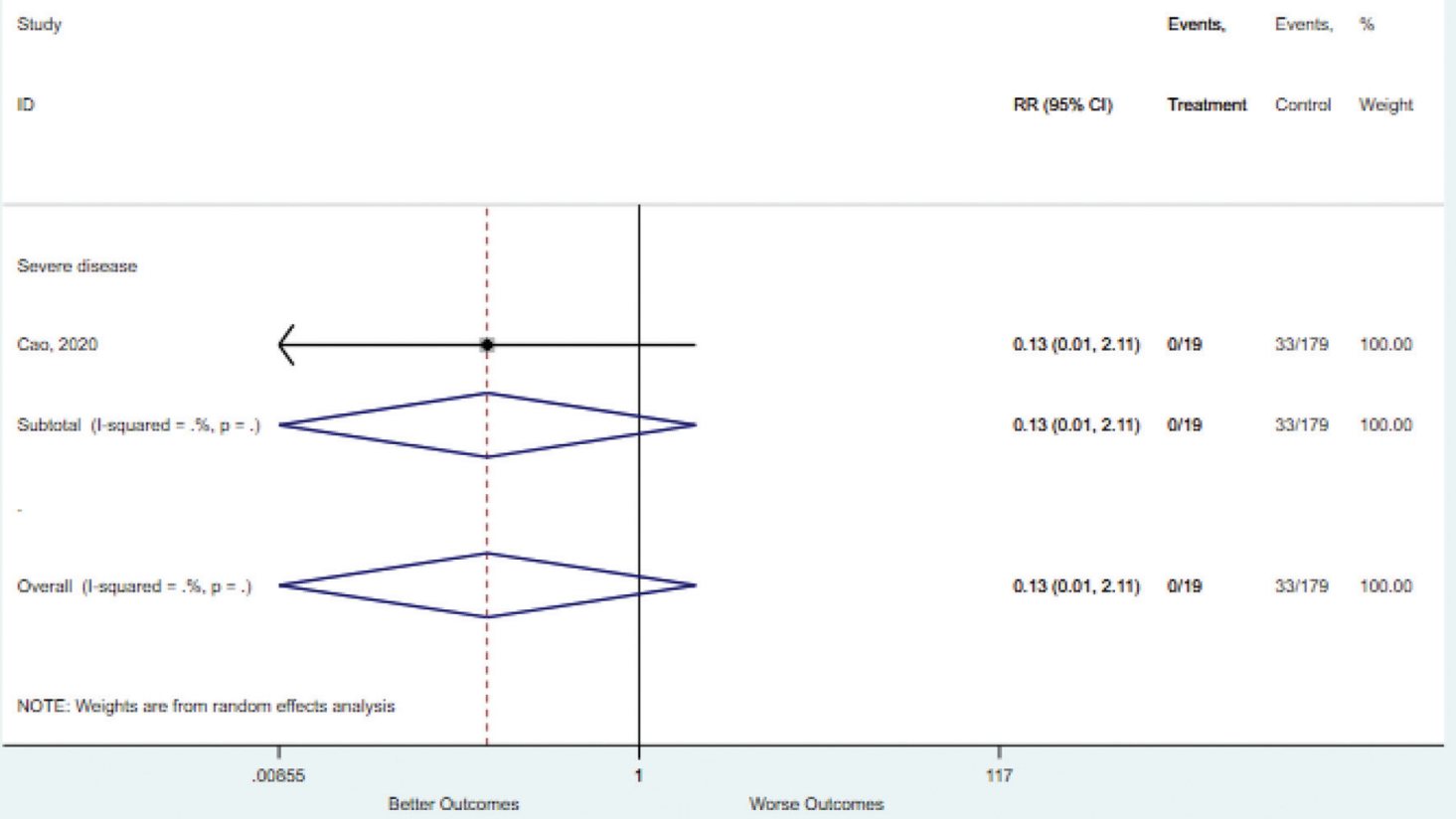


Age 60-69 years

Study

ID
Events, Events, \%

RR $(95 \% \mathrm{Cl}) \quad$ Treatment Control Weight

Severe disease

Cao, 2020

Subtotal (l-squared $=. \%, p=$.)

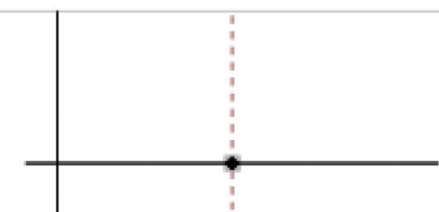

$1.74(0.90,3.33) 7 / 19$

$38 / 179 \quad 100.00$

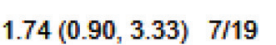

$38 / 179 \quad 100.00$

Overall (I-squared $=. \%, \mathrm{p}=$. )

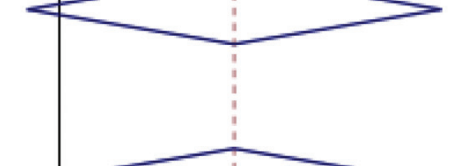

$1.74(0.90,3.33) 7 / 19$

$38 / 179 \quad 100.00$

NOTE: Weights are from random effects analysis

3

Better Outcomes

1

Worse Outcomes

3.33

Age 60 to 75 years

Study

Events, Events, \%

ID

RR $(95 \% \mathrm{Cl}) \quad$ Treatment Control Weight

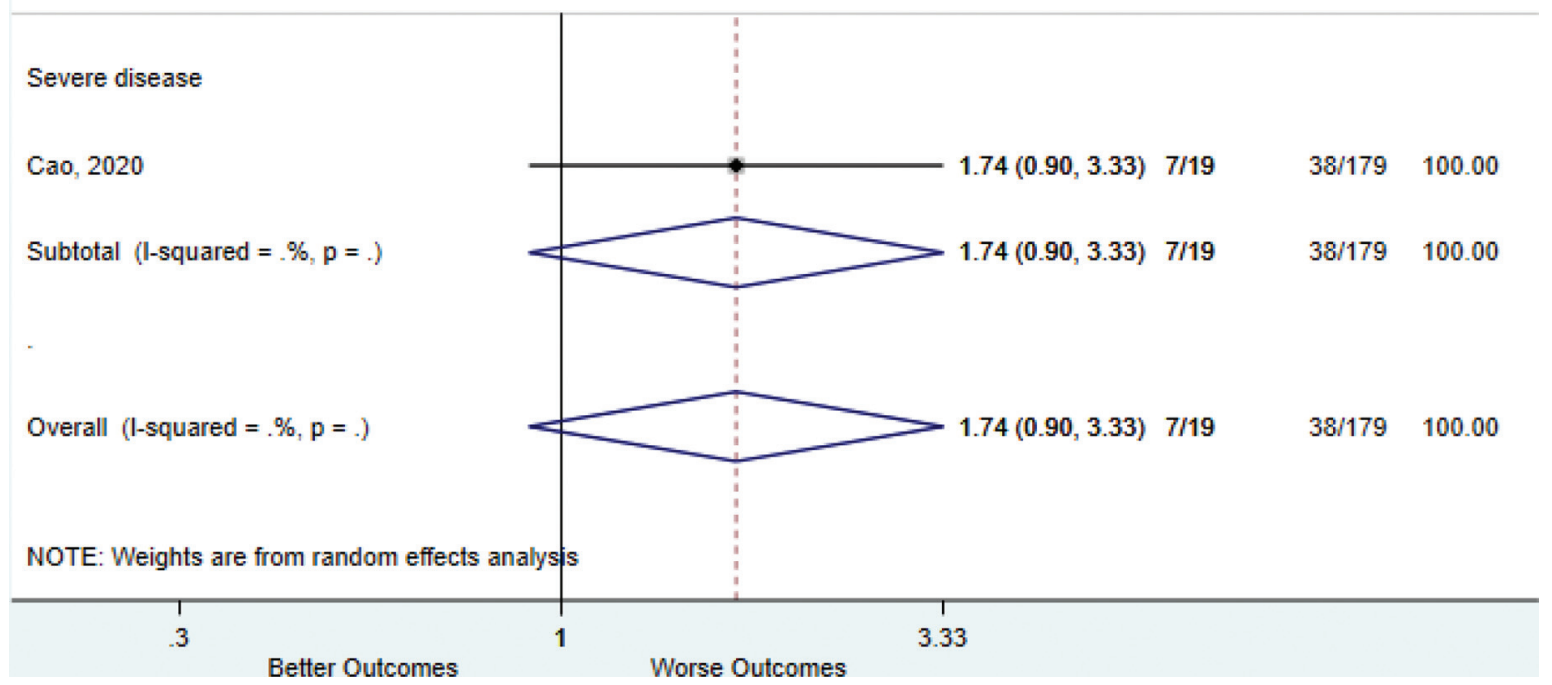


Age $\geq 40$ years

Study

ID
Events, Events, \%

RR $(95 \% \mathrm{Cl}) \quad$ Treatment Control Weight

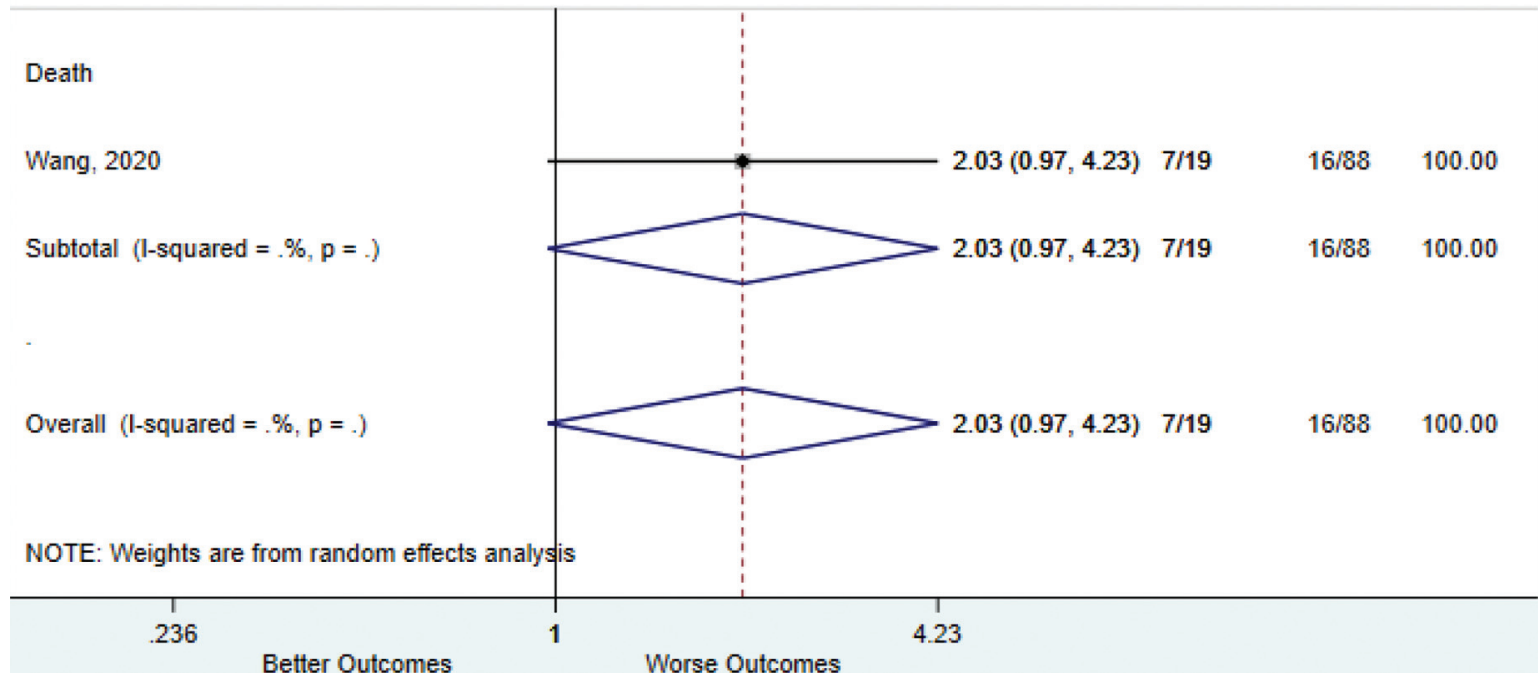

Age $\geq 50$ years

Study

ID

\section{Desth}

Chen, 2020

Subtotal (1-squared $=. \%, p=$.)

Severe disease

Cao, 2020

Subtotal (l-squared $=\%, p=$.)

Severe disease or death

Hu, 2020

Subtotal (l-squared $=\%, p=$.)

Overall (1-squared $=94.3 \%, p=0.000)$

NOTE: Weights are from random effects analysis 1
584
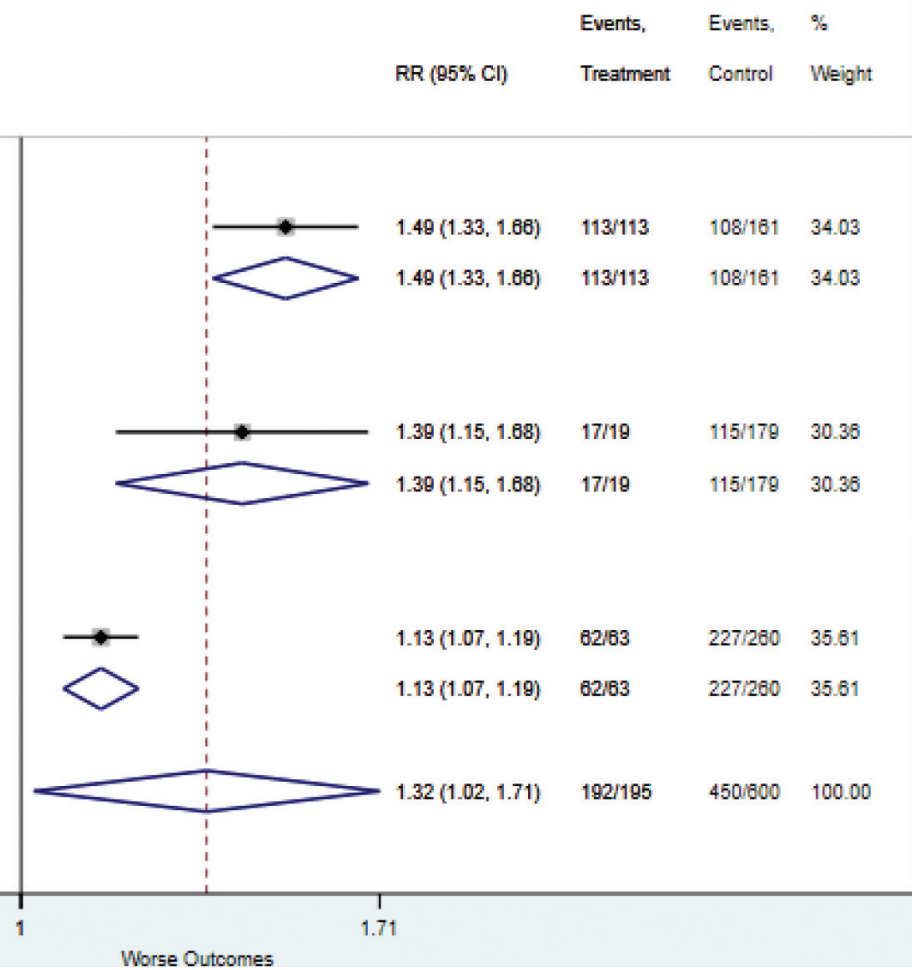
Age $\geq 60$ to 65 years

Study

Events, Events, \%

ID

RR (95\% Cl)

Treatment

Control Weight

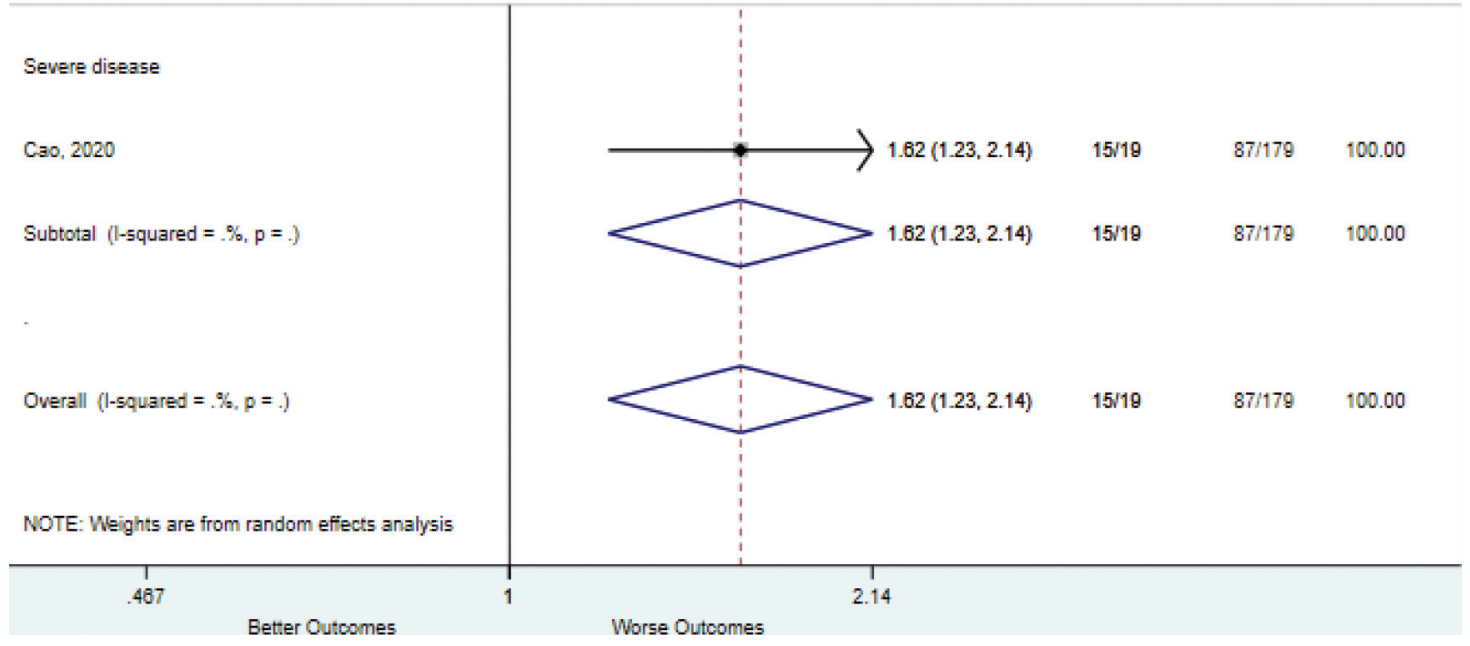

Age $\geq 70$ years

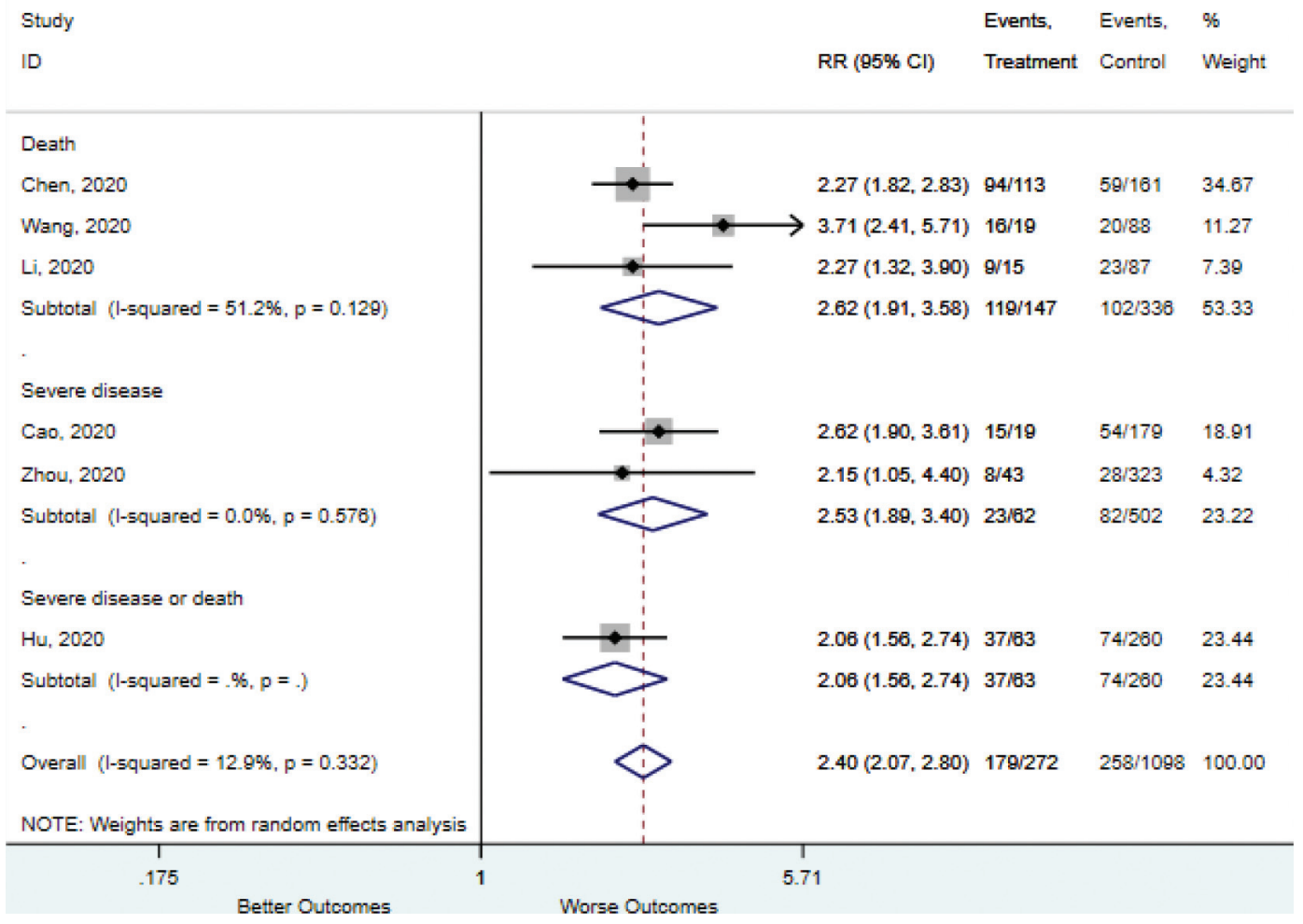




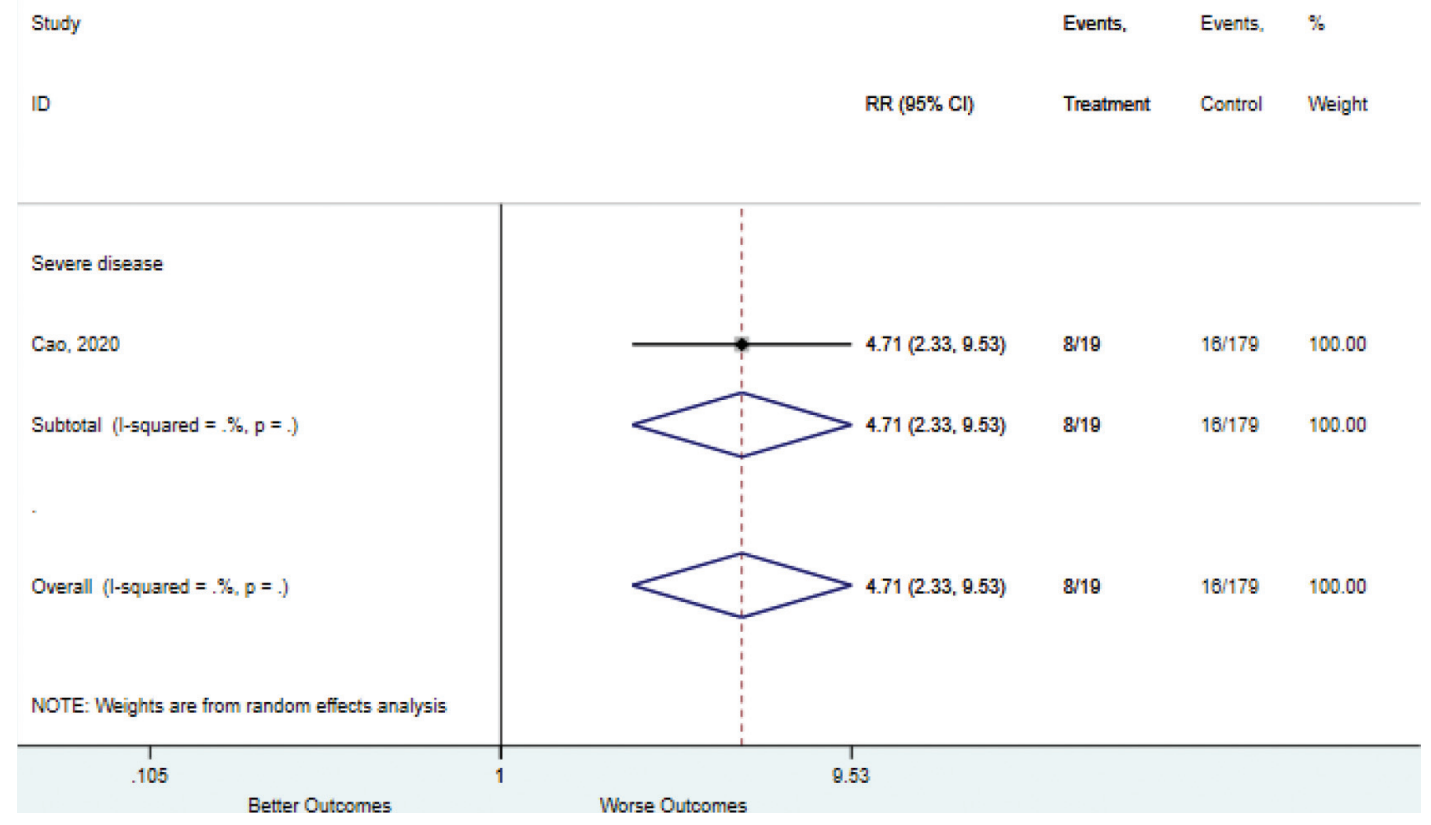

Age $>75$ years

Study

ID

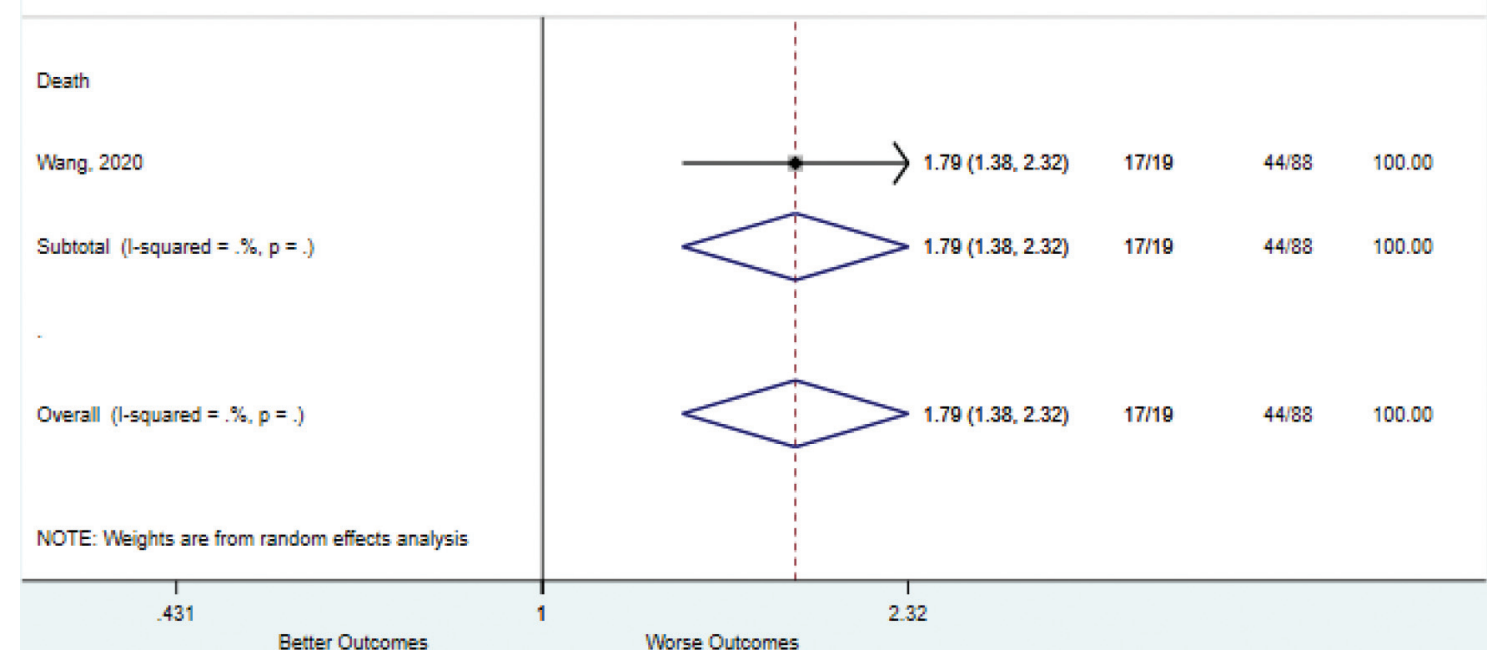

Events, Events, \%

RR (95\% Cl) Treatment Control Weight 
Age $<39$ to 40 years

Age $<45$ years

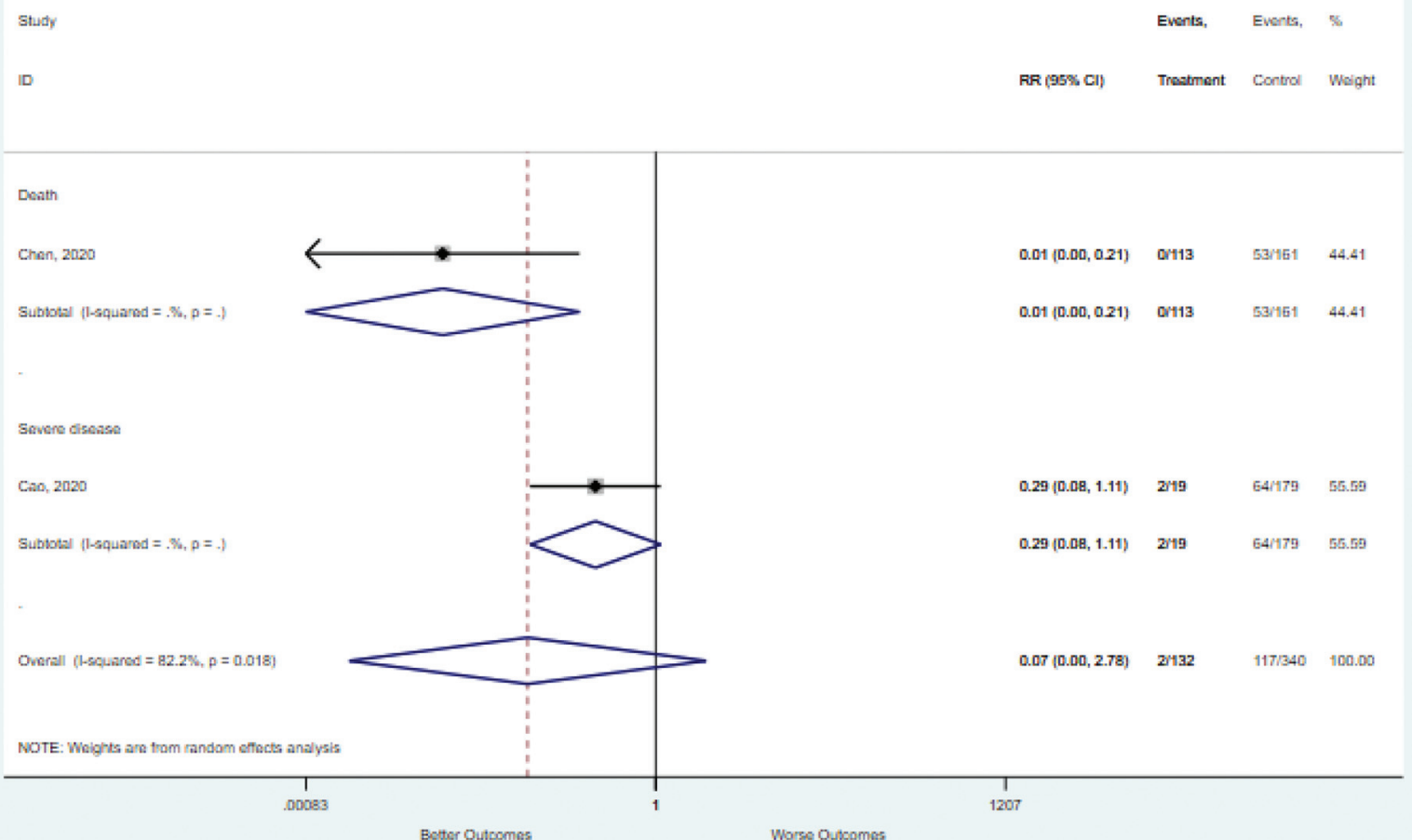


Any comorbidity
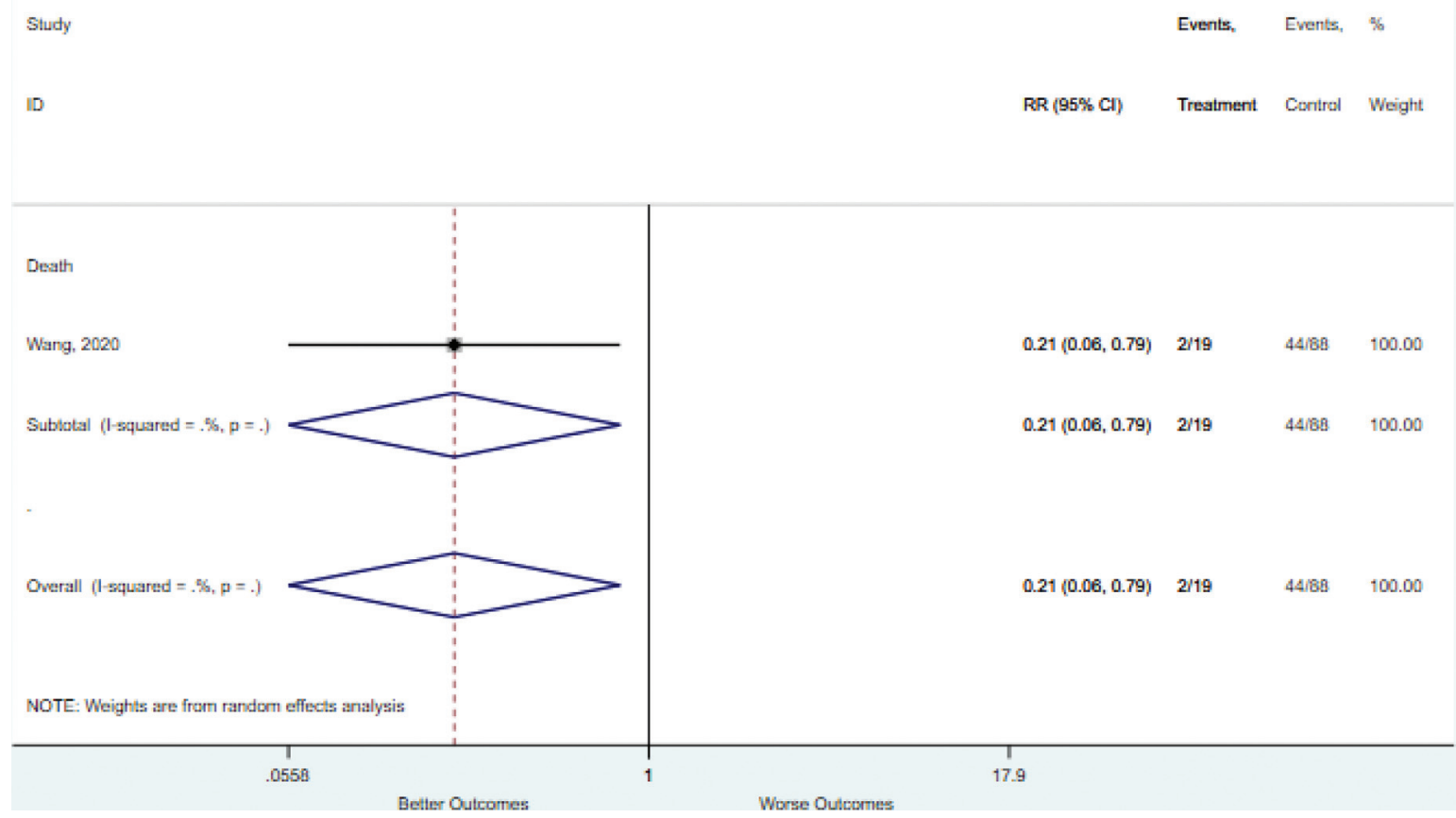

Asthma or COPD

Study

ID
Events, Events, \%

RR $(95 \% \mathrm{Cl}) \quad$ Treatment Control Weight

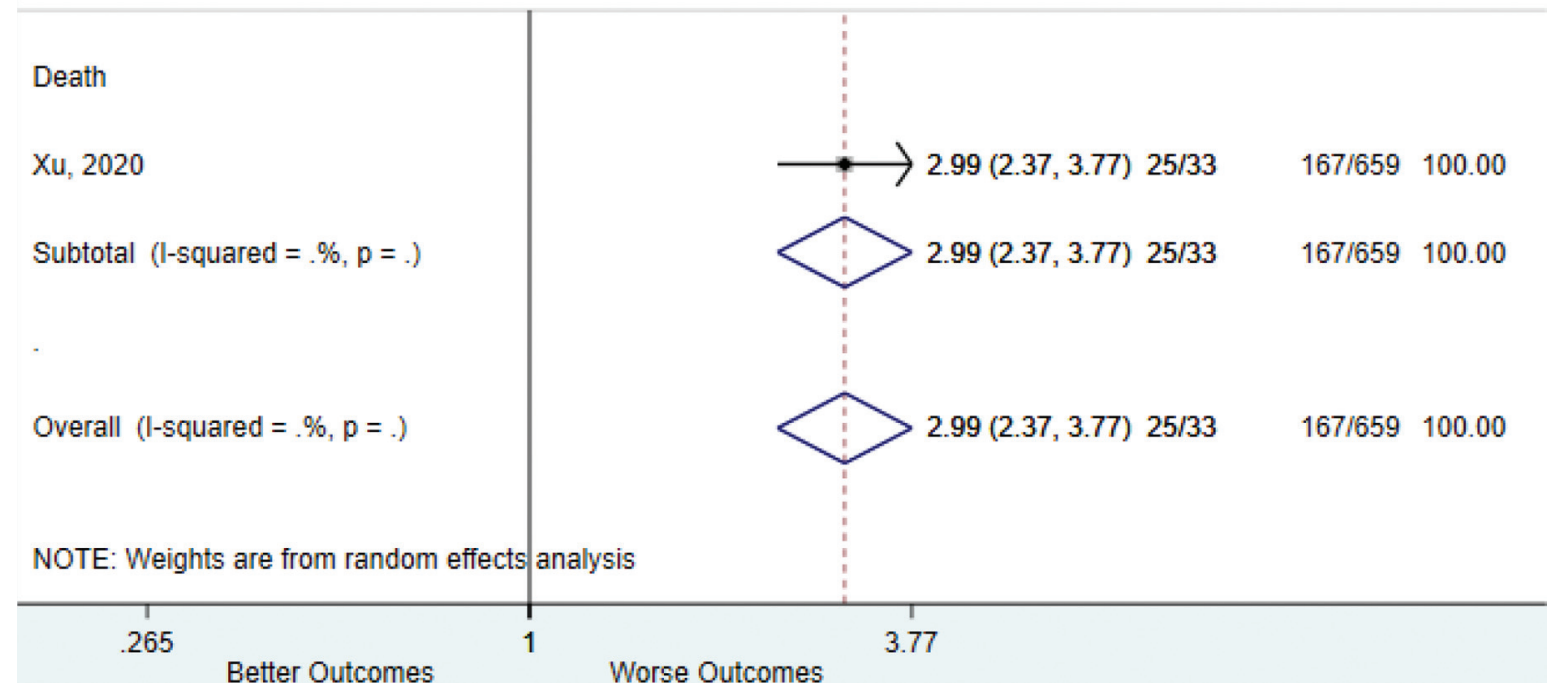




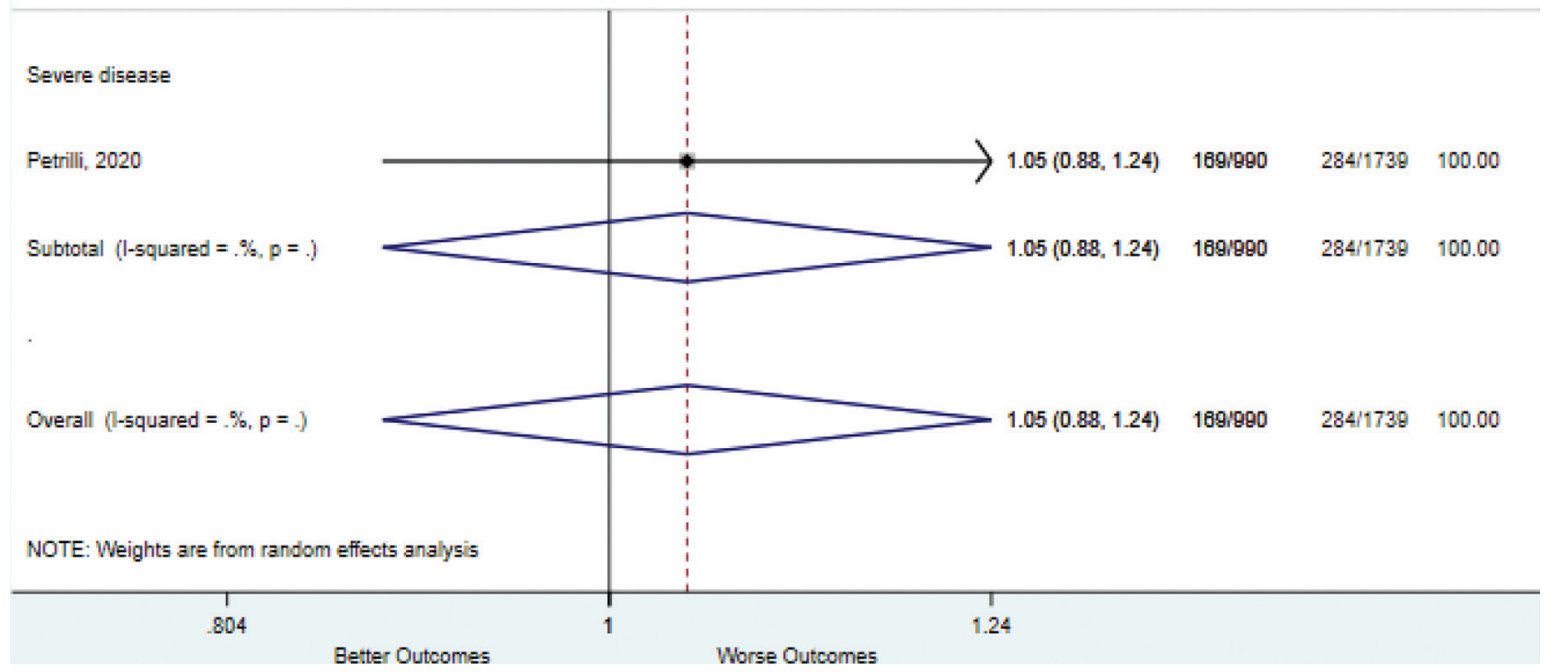

Cough

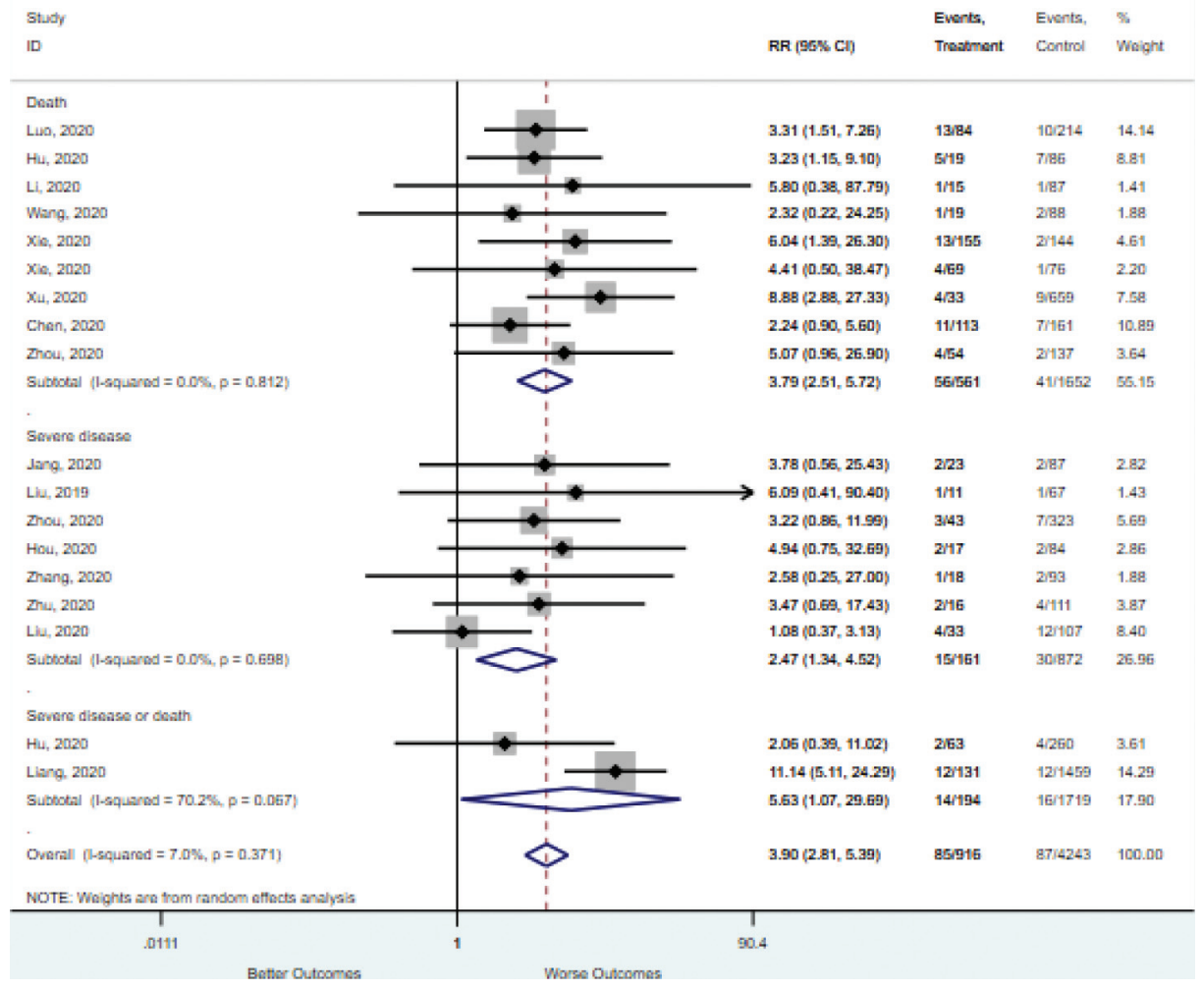




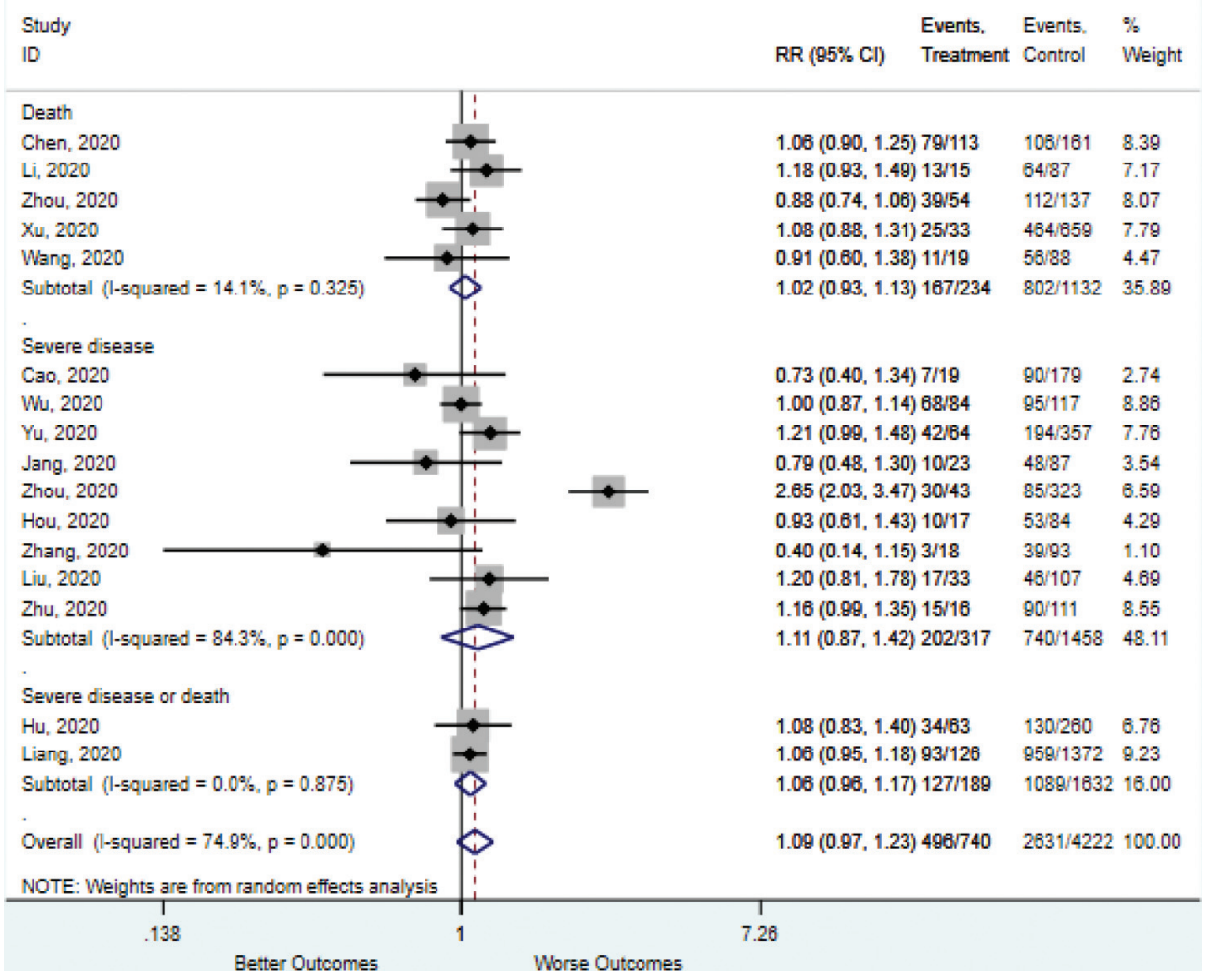

$\mathrm{CRP} \geq 5$ to 10

Study

ID
Events, Events, \%

RR $(95 \% \mathrm{Cl}) \quad$ Treatment Control Weight

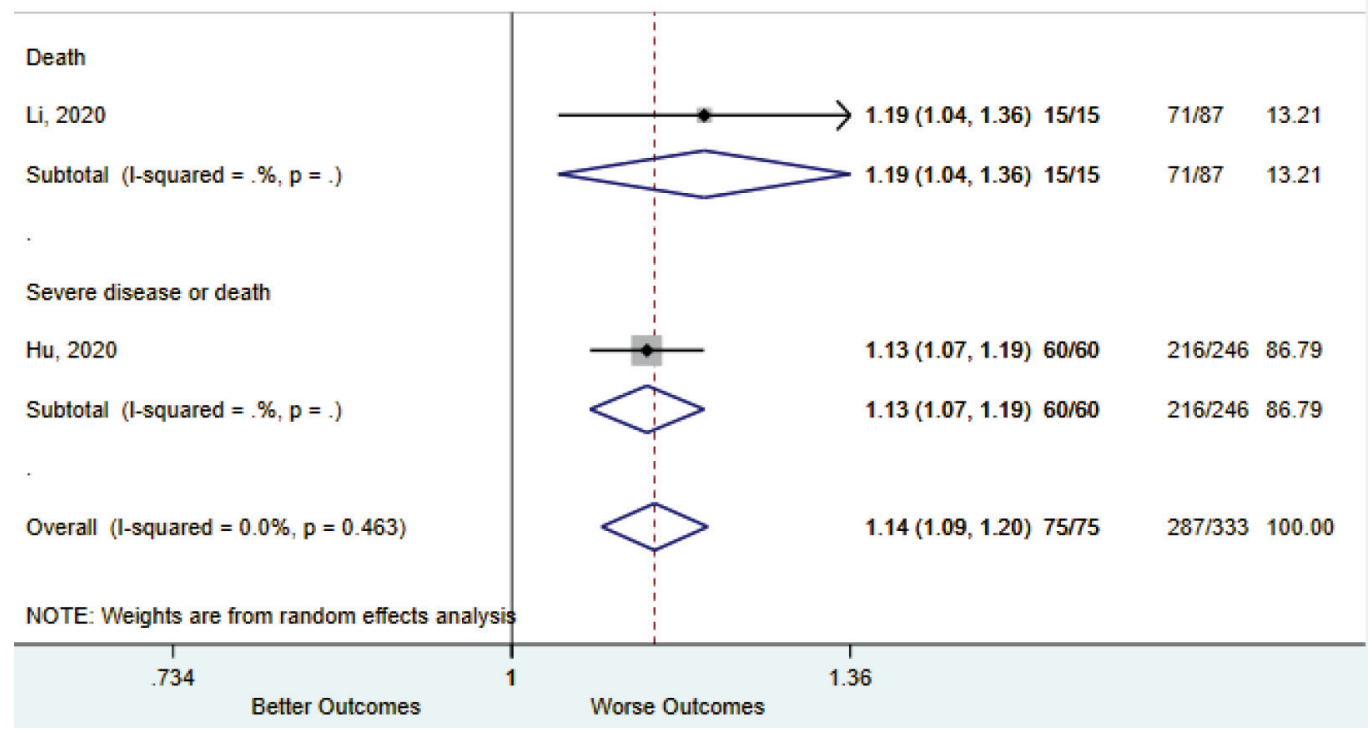


$\mathrm{CRP} \geq 100$

Study

$\begin{array}{ccc} & \text { Events, } & \text { Events, } \% \\ \text { RR }(95 \% \mathrm{Cl}) & \text { Treatment } & \text { Control Weight }\end{array}$

ID

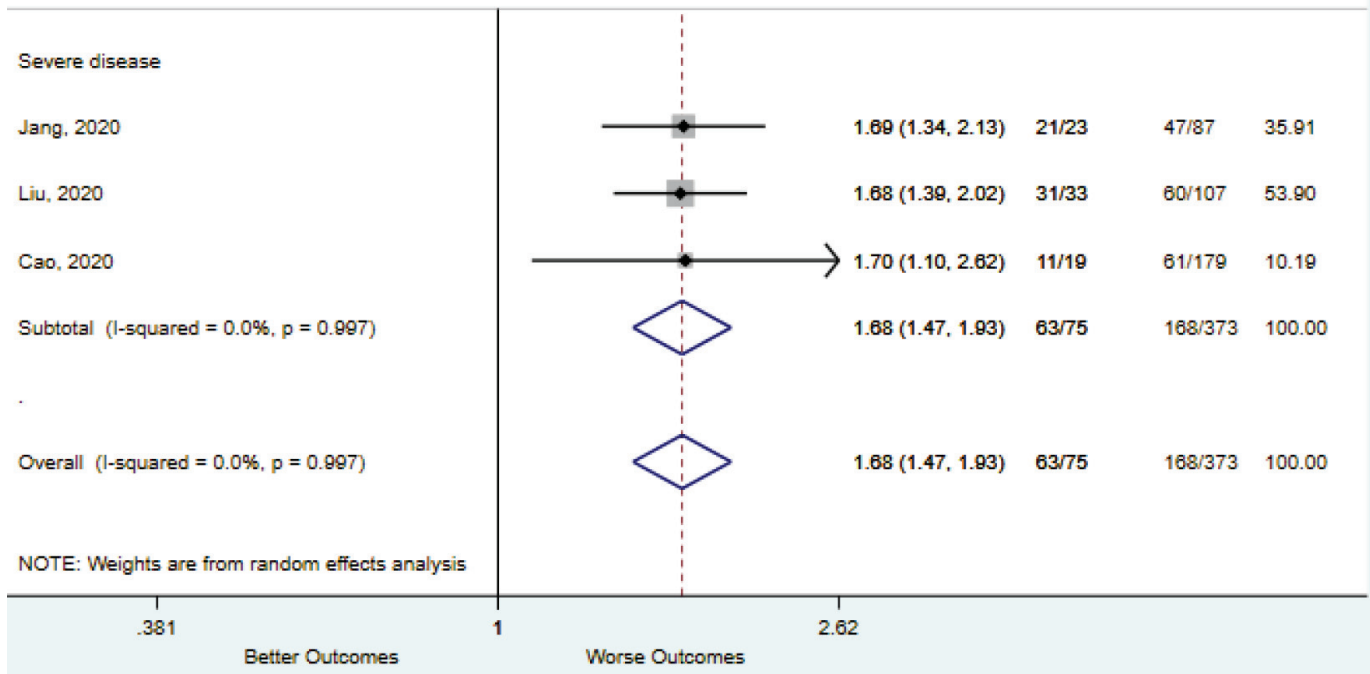

CRP increased

Study

ID

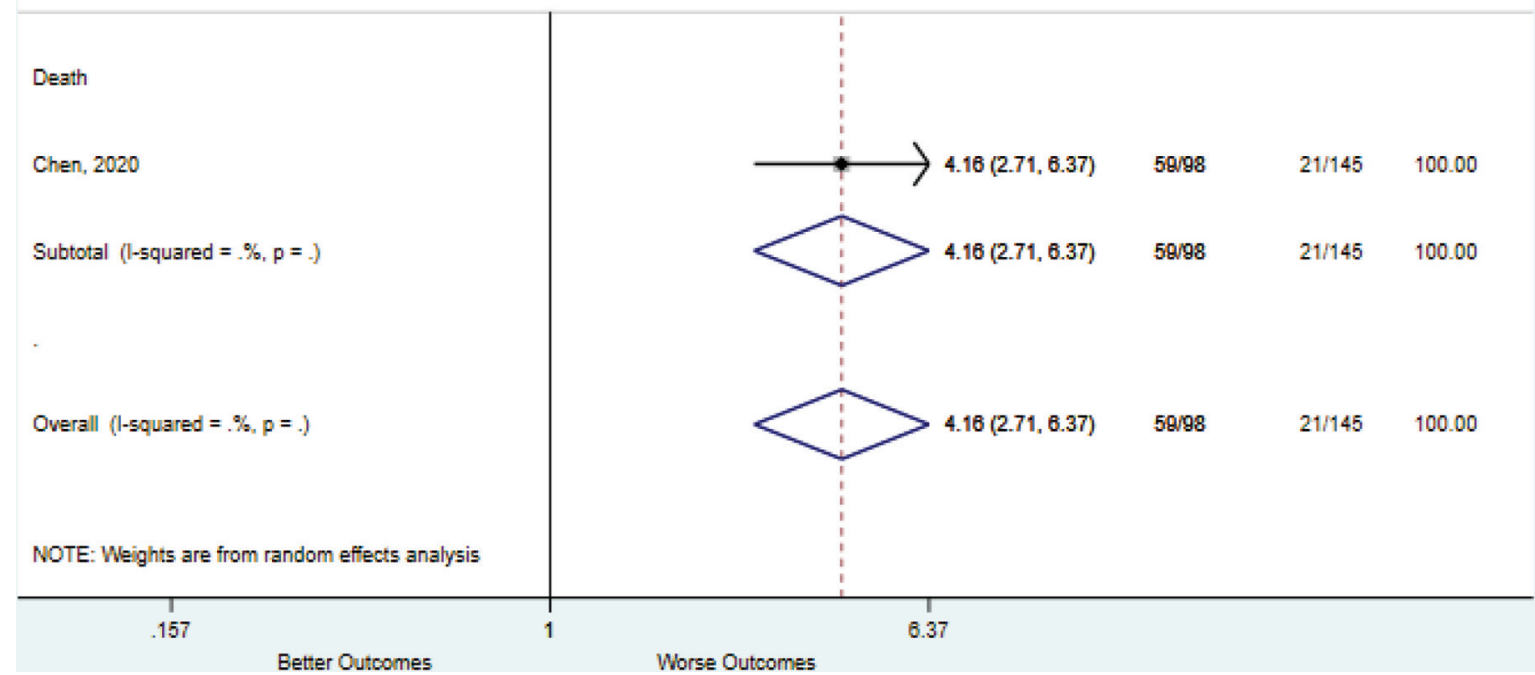

Events, Events, \%

RR $(95 \%$ Cl) Treatment Control Weight 
D-dimer 0.5-1.0

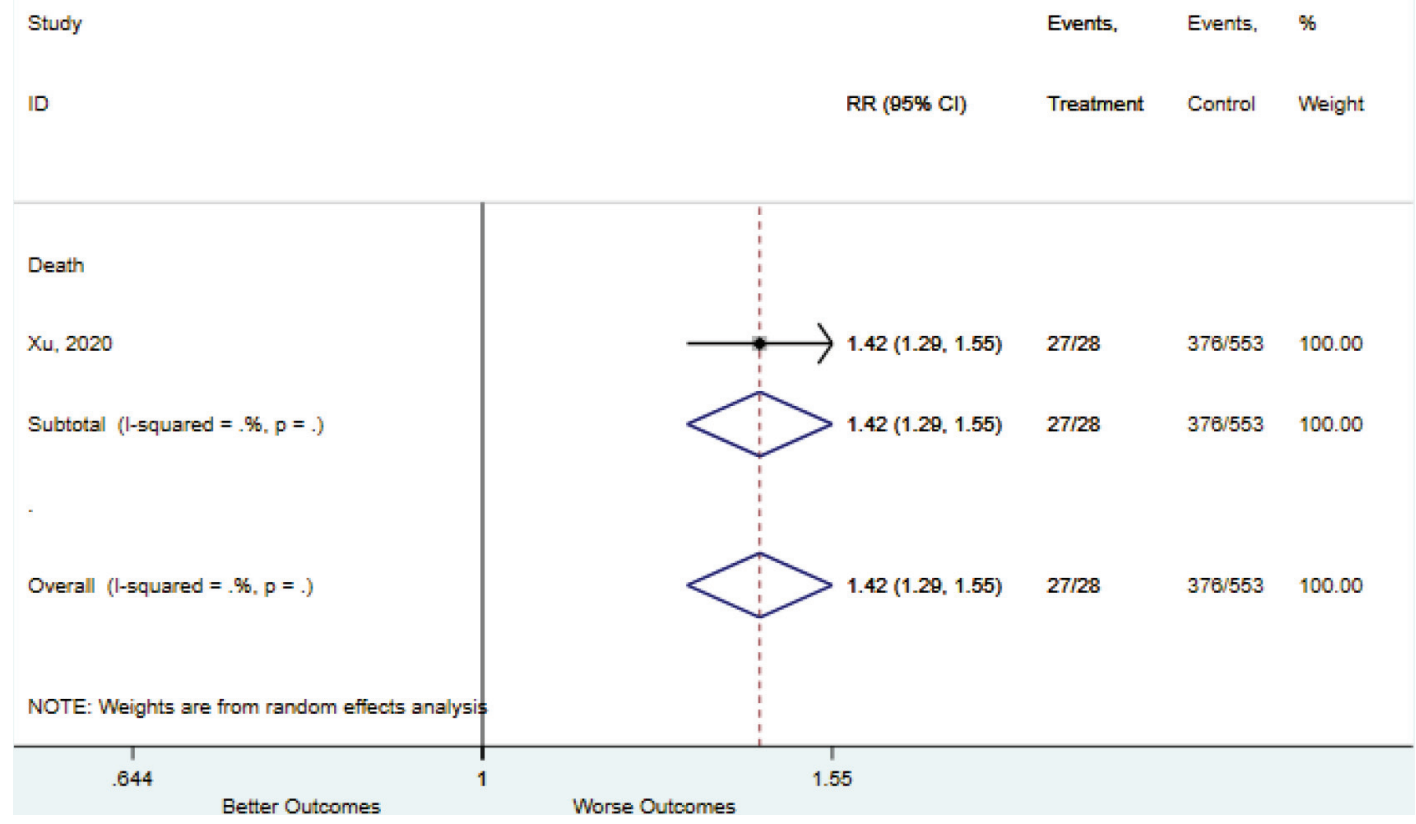

D-dimer $\geq 0.5$

$n$

ID

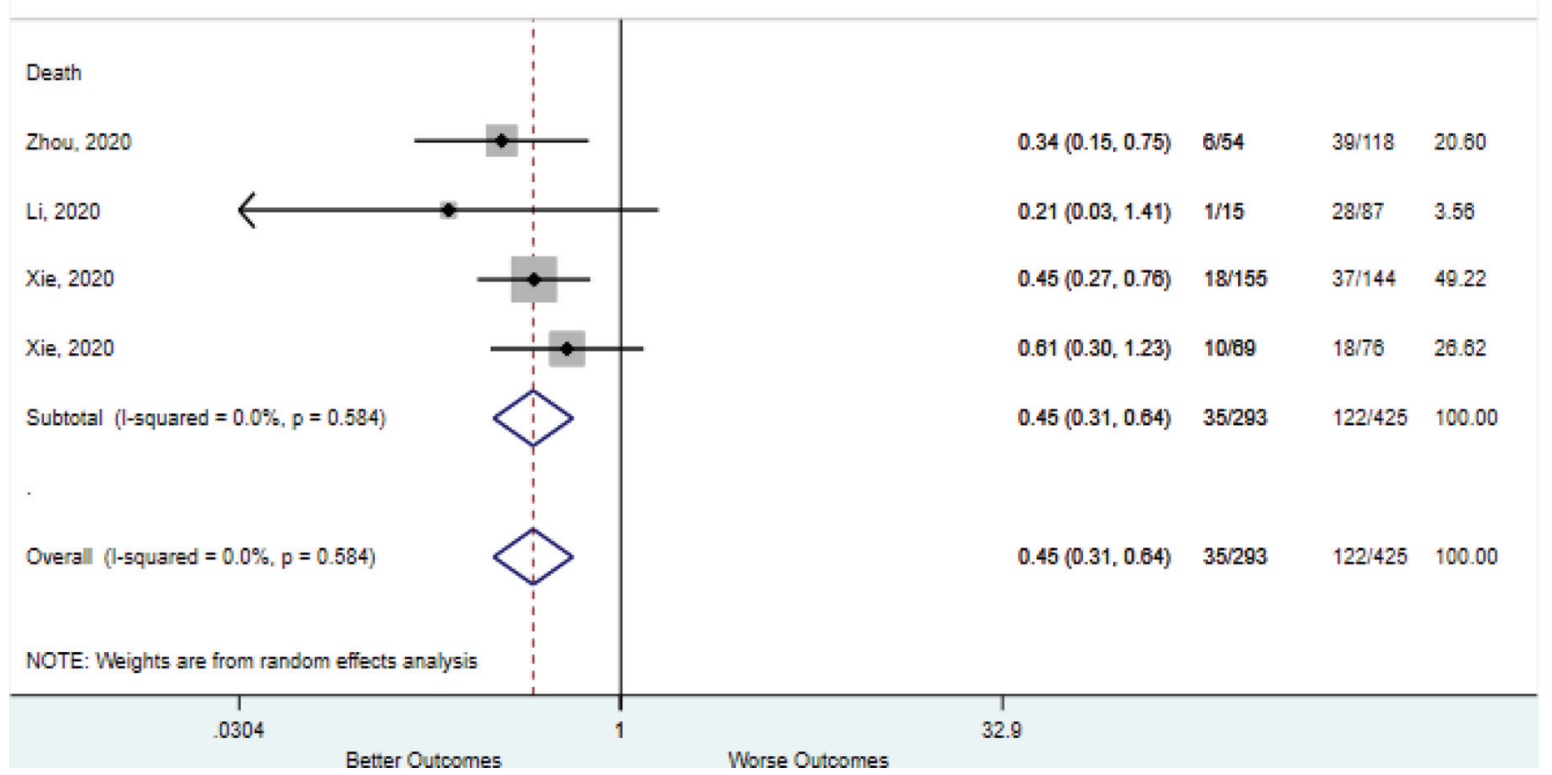


D-dimer $\geq 1.0$

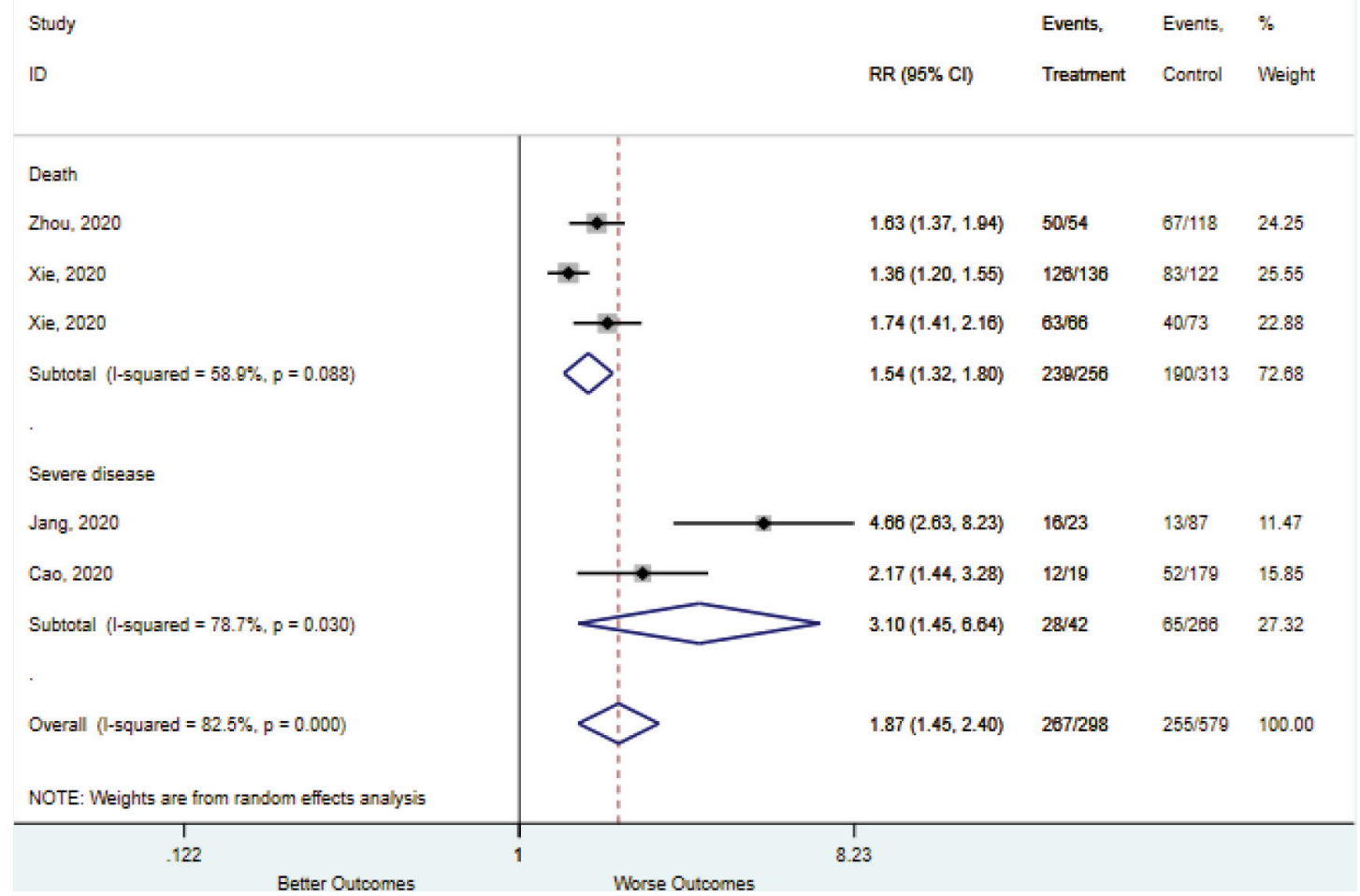

D-dimer $>21$

Study

ID

Li, 2020

Xie, 2020

Xie, 2020

Zhou, 2020

Subtotal (l-squared $=32.5 \%, p=0.217$ )

Overall (l-squared $=32.5 \%, p=0.217)$

NOTE: Weights are from random effects analysis

.208

$\mathrm{RR}(95 \% \mathrm{Cl})$

$$
\begin{array}{ll}
\text { Events, } & \text { Events, } \% \\
\text { Treatment } & \text { Control Weight }
\end{array}
$$


D-dimer increased

D-dimer $\leq 0.5$
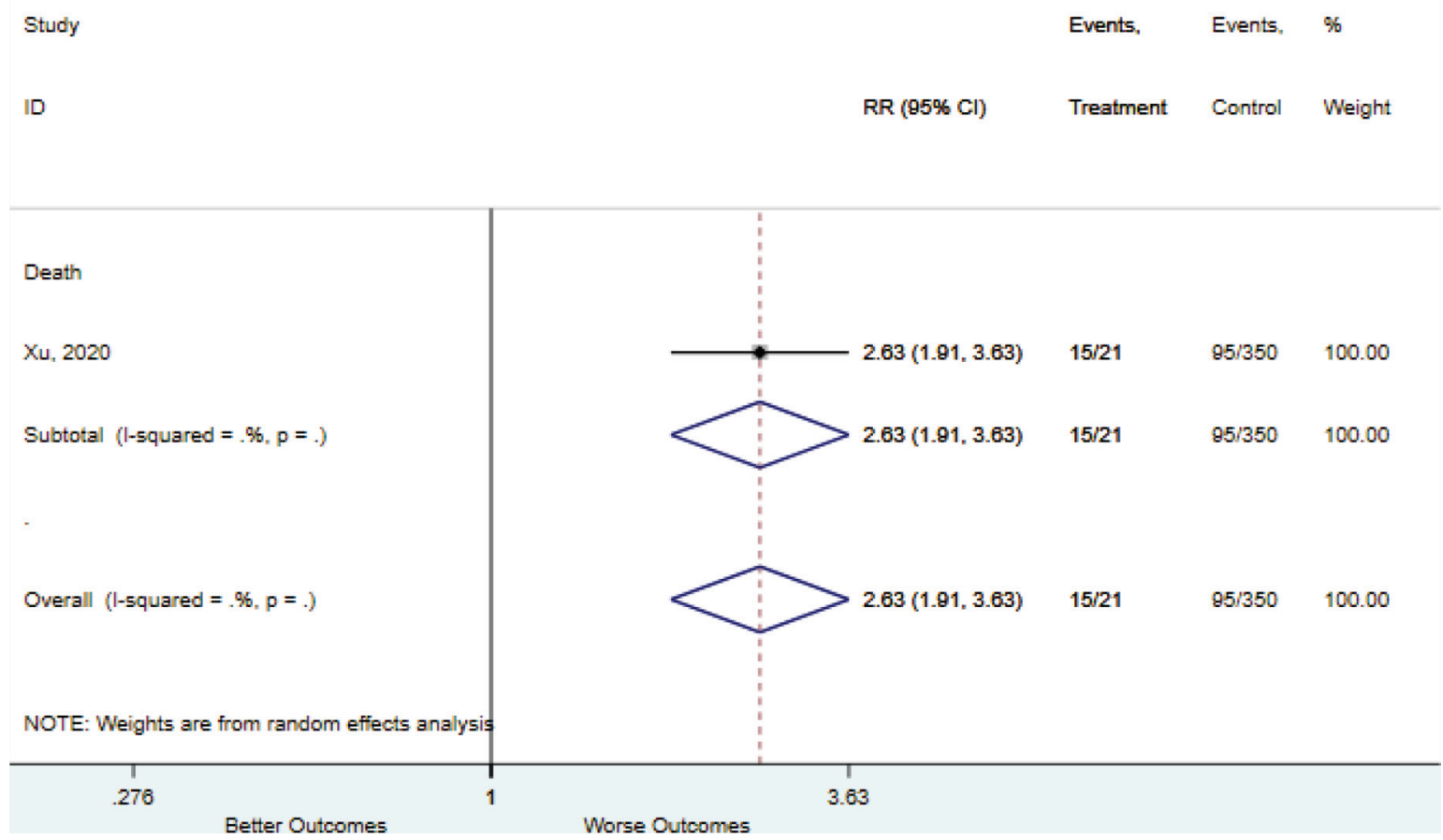
Diabetes

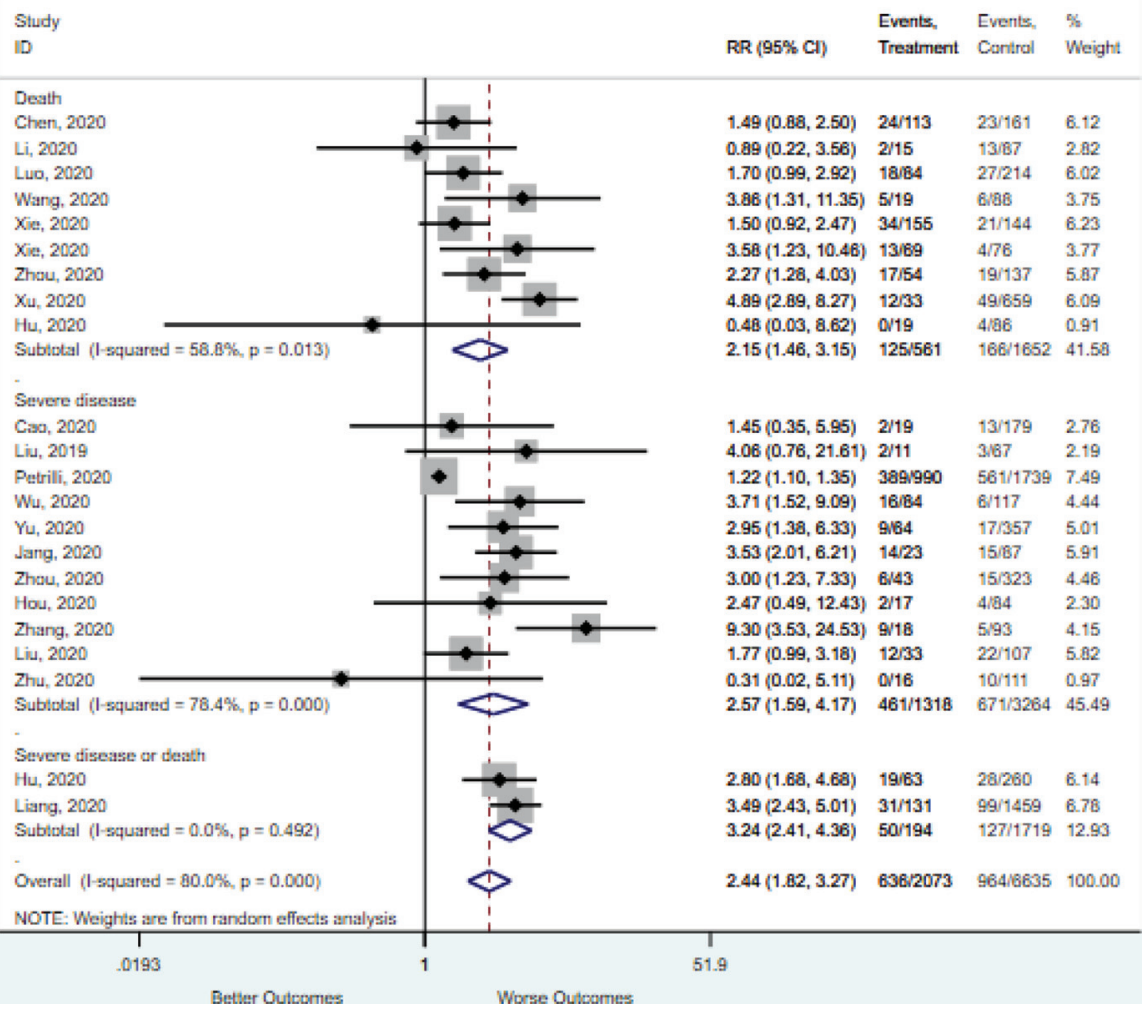


Fever

Study
ID


Heart rate $\geq 90$

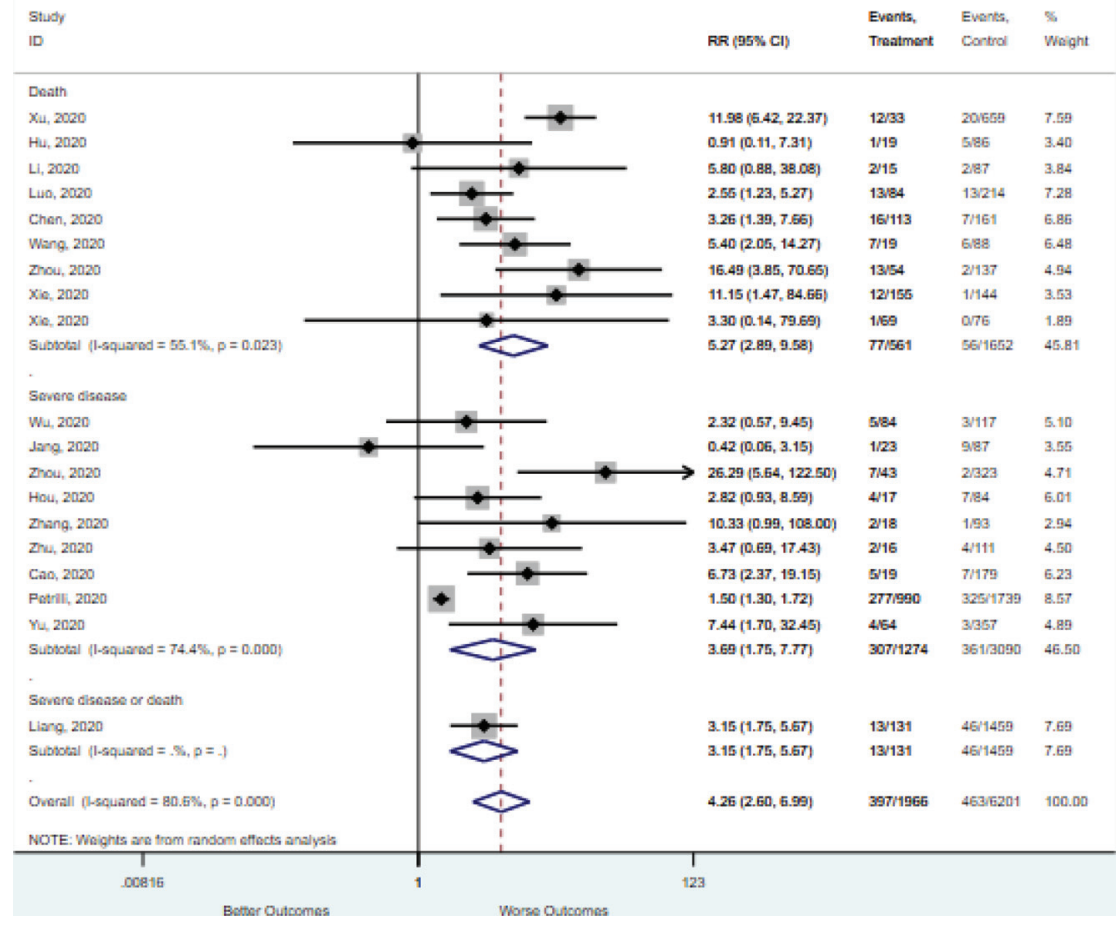

Heart rate $\geq 125$

Study

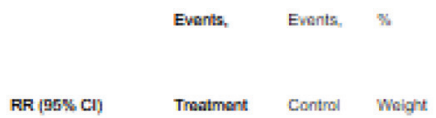

ID

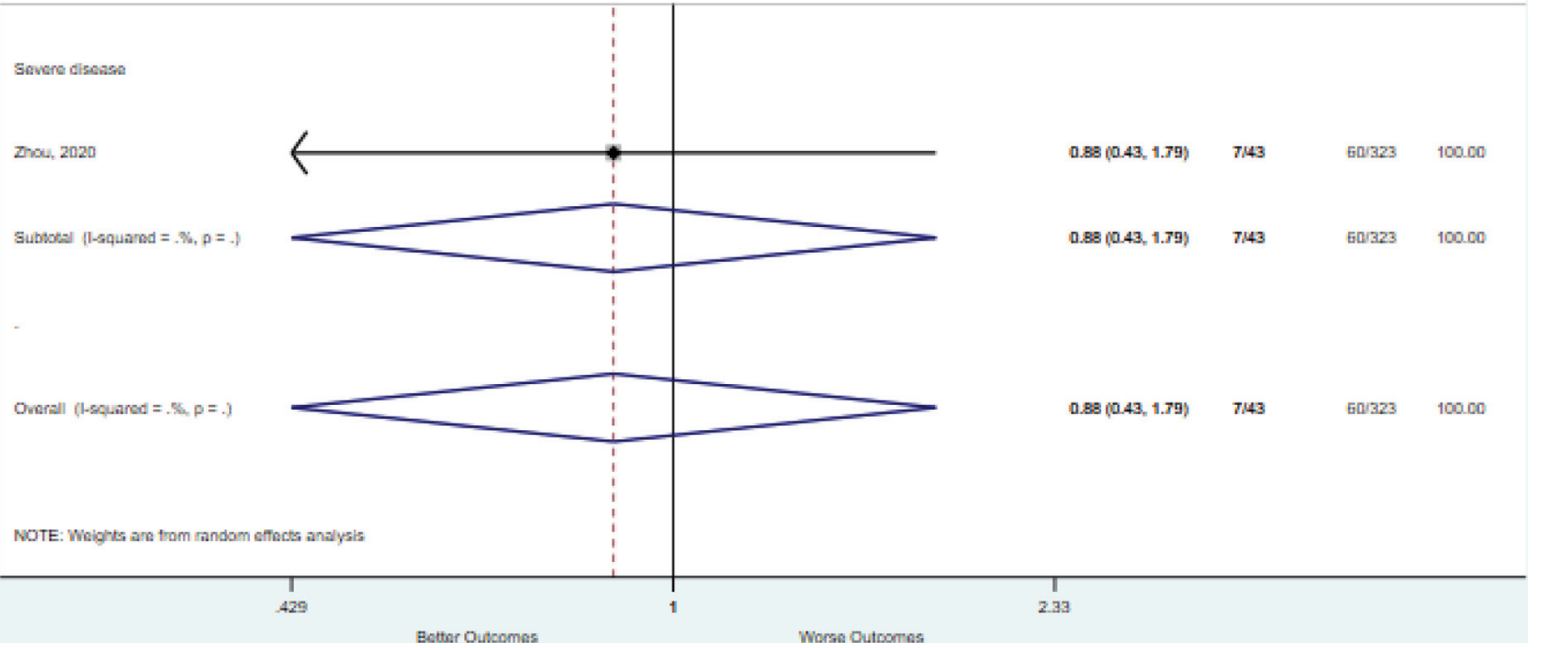


Heart rate $>100$

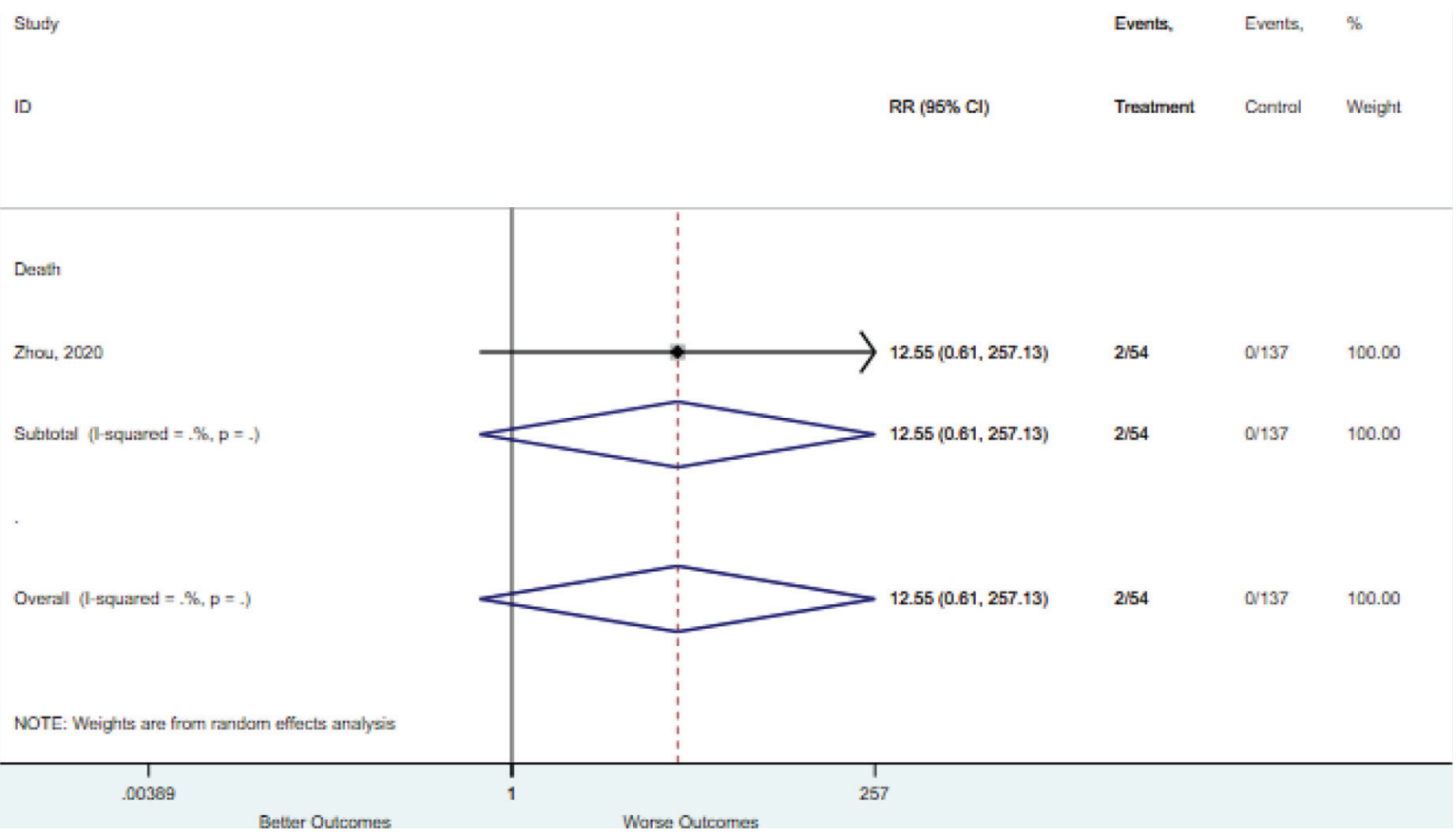

Hypertension

Study

ID

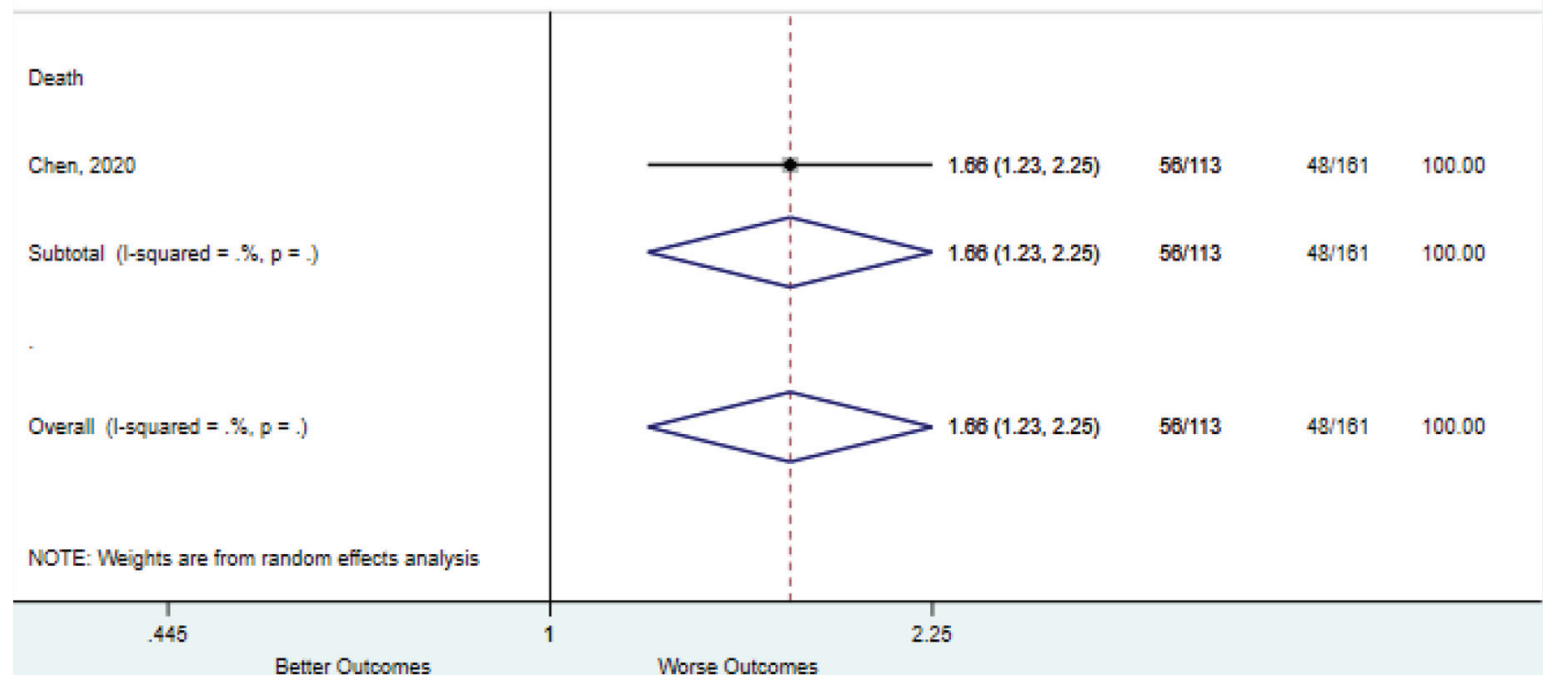


Kidney disease

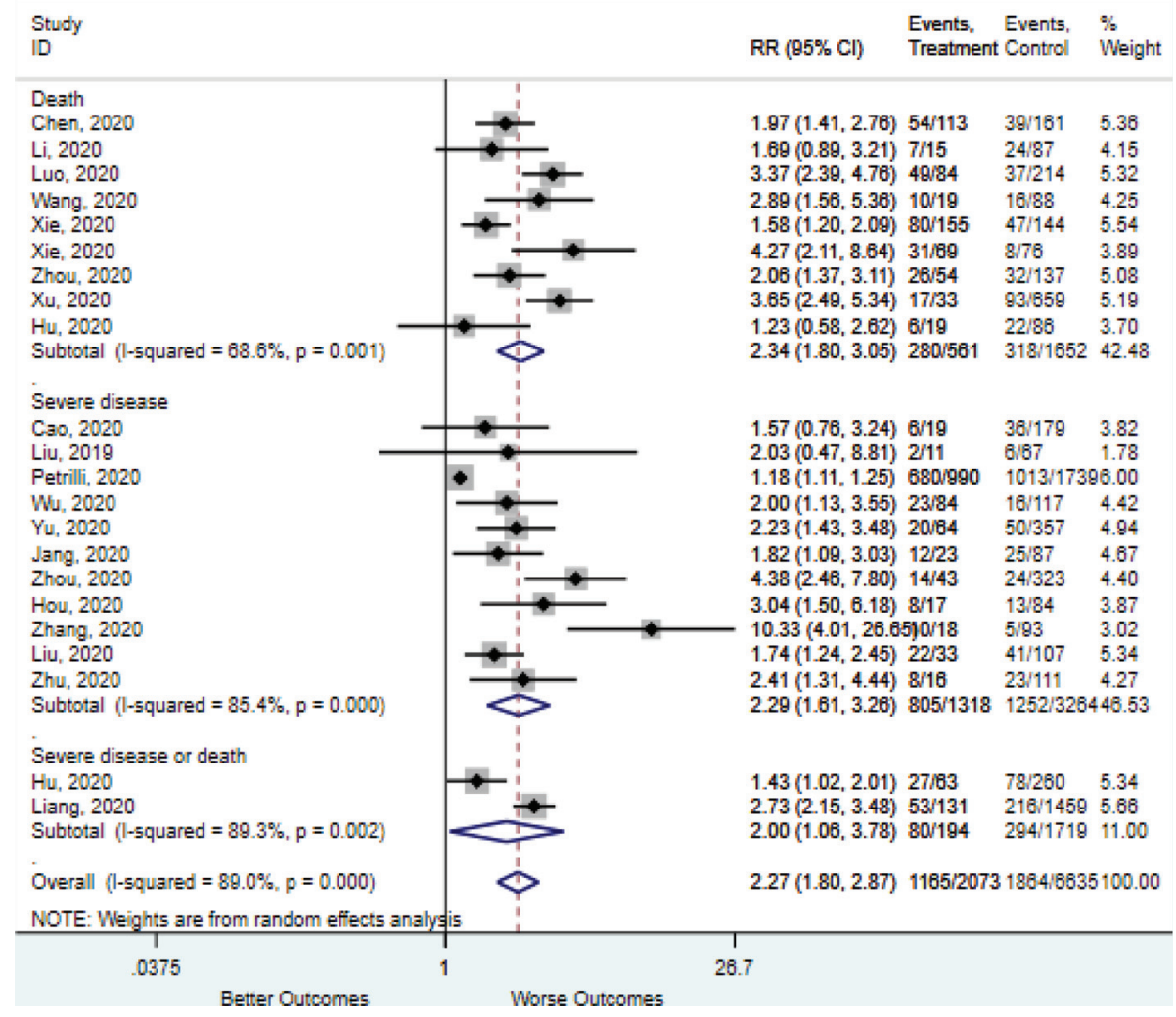

LDH increased

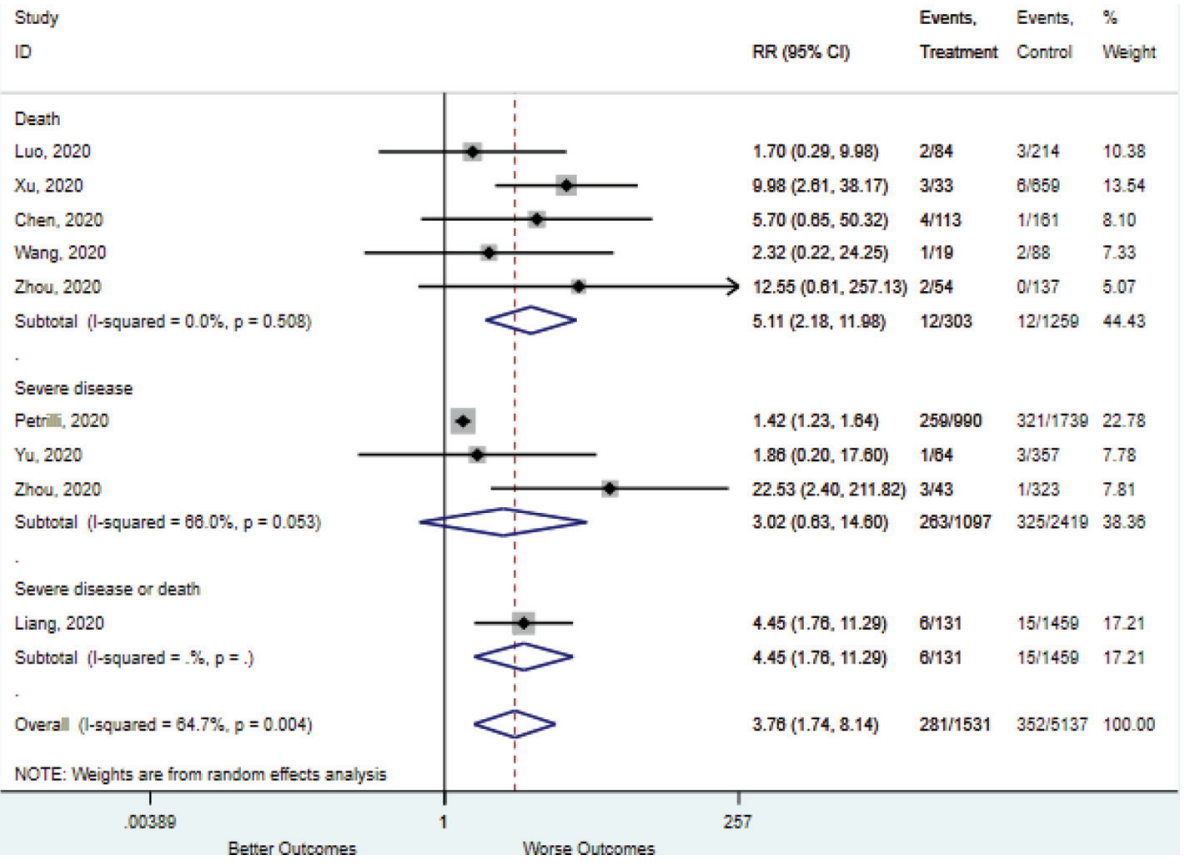


Lymphocyte $0.8-1.0$

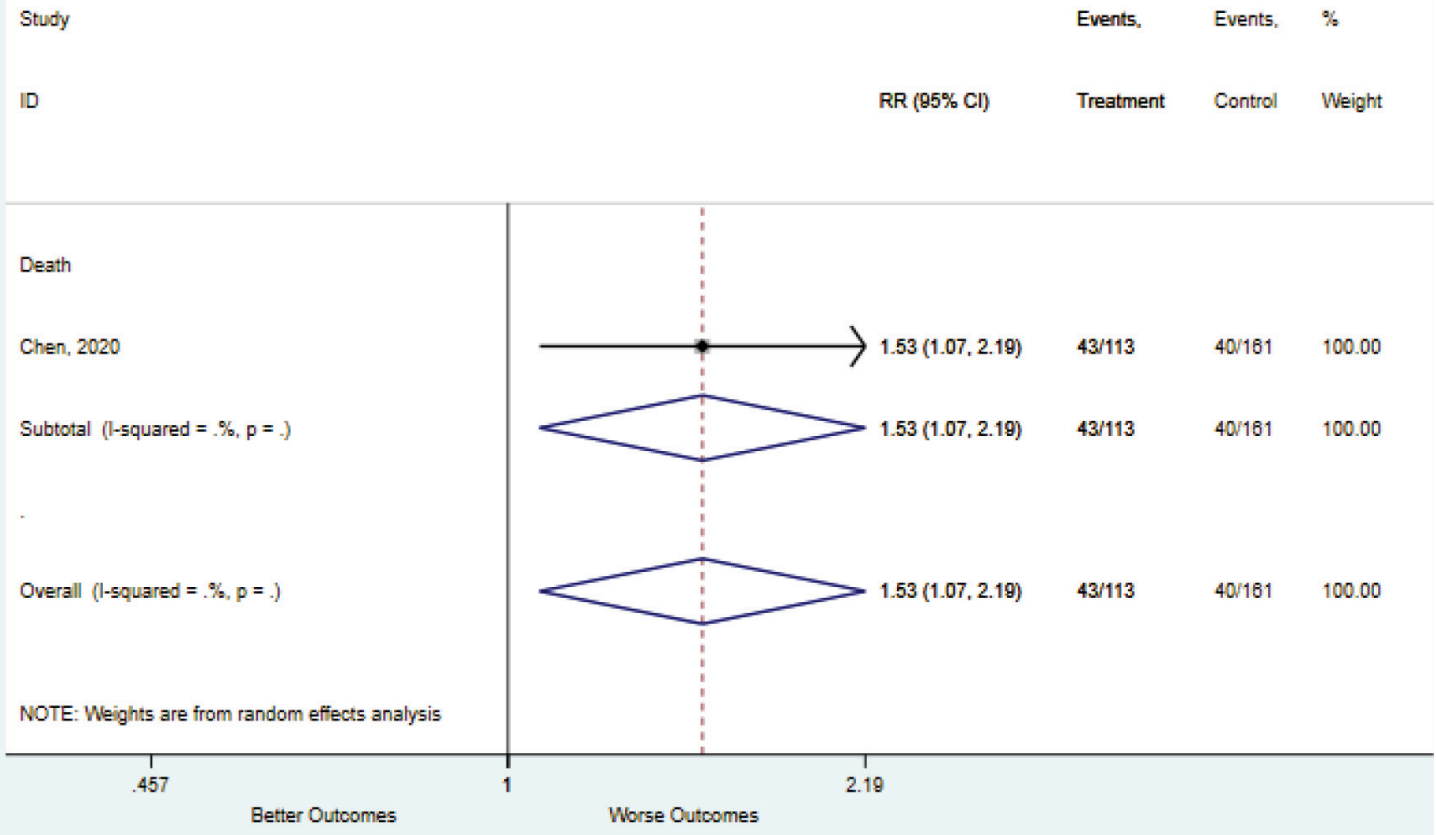


Lymphocyte $\geq 1.0$

Events, Events, \%

ID

RR (95\% Cl) Treatment Control Weight

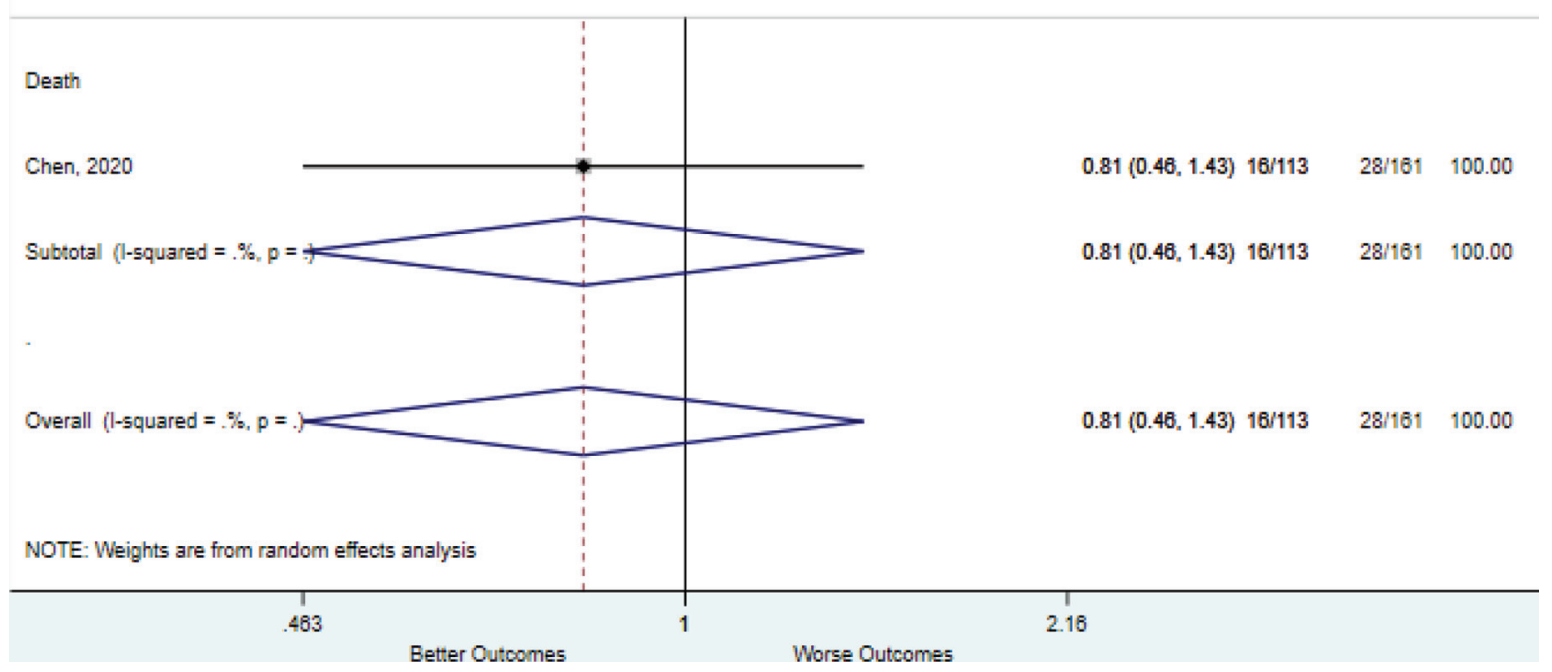

Lymphocyte $>3.2$

Study

15

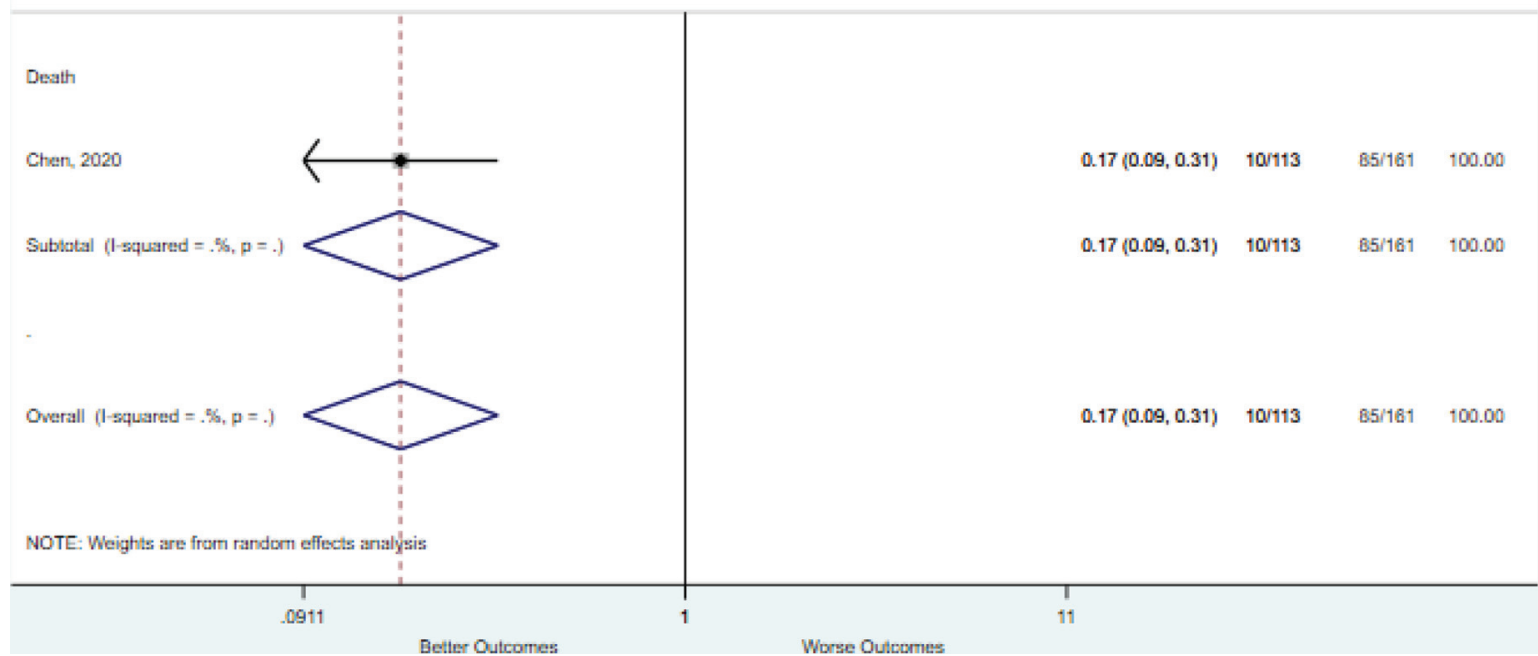


Lymphocyte $<0.5$

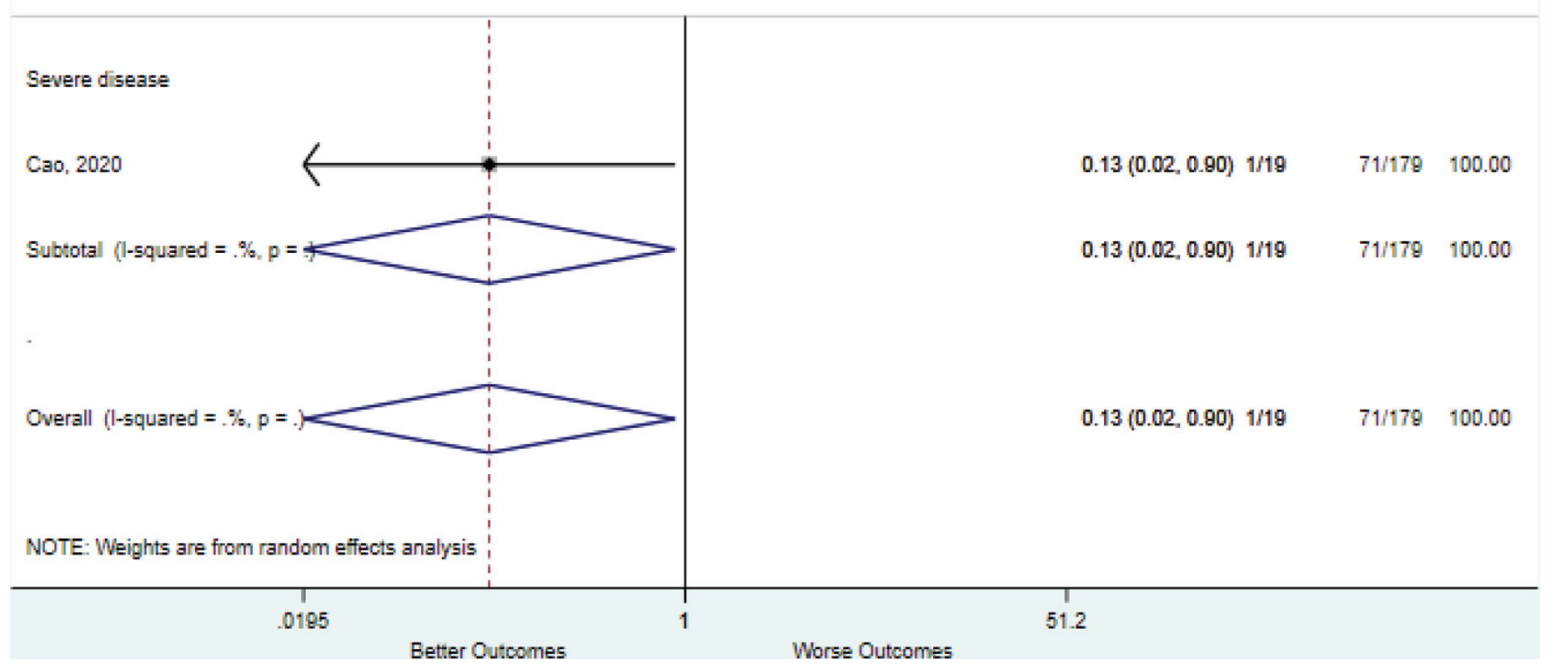

Lymphocyte $<0.8$ to 1.1

Study

ID

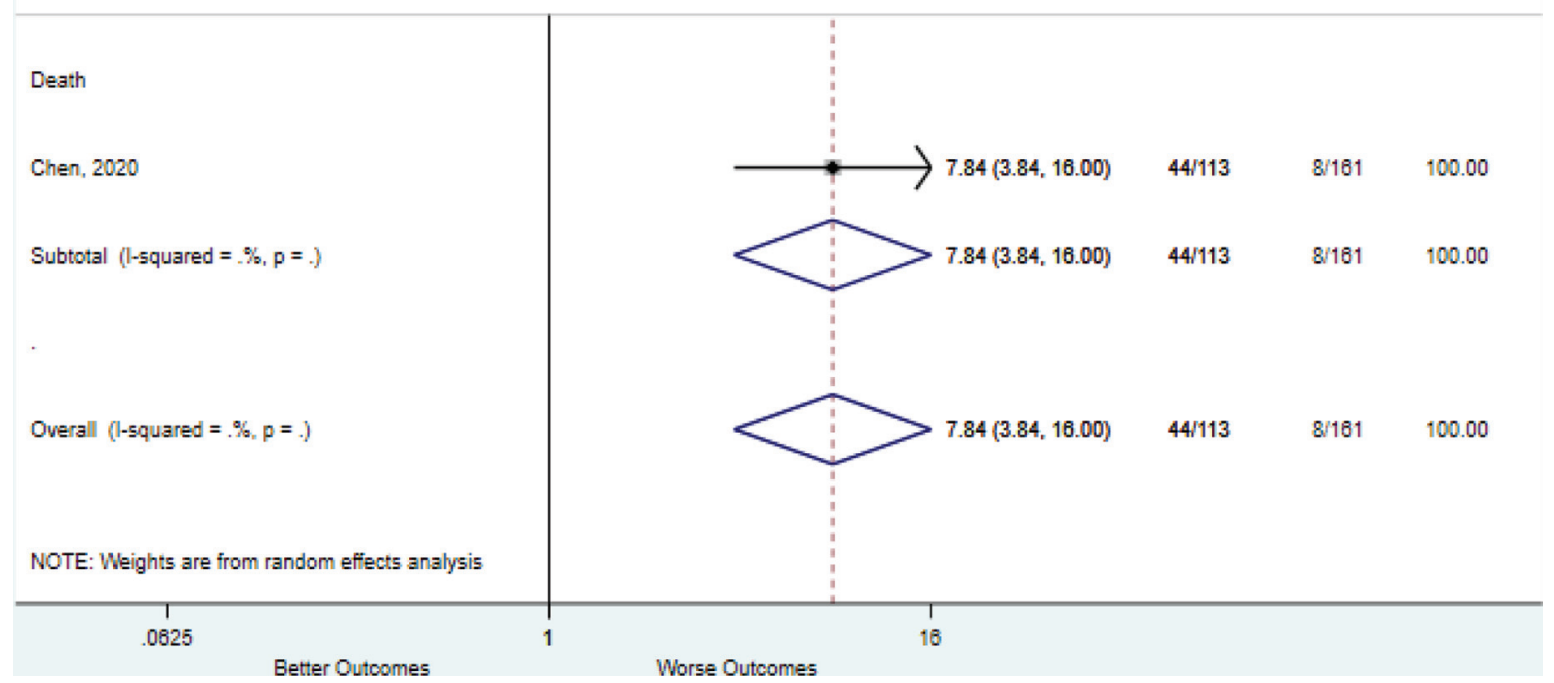

Events, Events, \%

RR (95\% Cl) Treatment Control Weight 
Lymphocyte $<2.0$

Lymphocytes decreased

$\begin{array}{llll}2.58(2.00,3.34) & 87 / 113 & 49 / 161 & 20.41 \\ 2.89(2.10,3.97) & 41 / 54 & 36 / 137 & 19.72 \\ 1.93(1.62,2.30) & 103 / 113 & 76 / 161 & 21.19 \\ 1.29(0.96,1.74) & 12 / 15 & 54 / 67 & 19.92 \\ 2.07(1.51,2.84) & 243 / 296 & 214 / 546 & 81.24\end{array}$

Savere tisease

Jang, 2020

Caso, 2020

Subintal (1-squared $=90.4 \%, p=0.001)$

Overall (1-squared $=90.3 \%, p=0.000)$

NOTE: Weights are frum random effects analysis

Study

ID

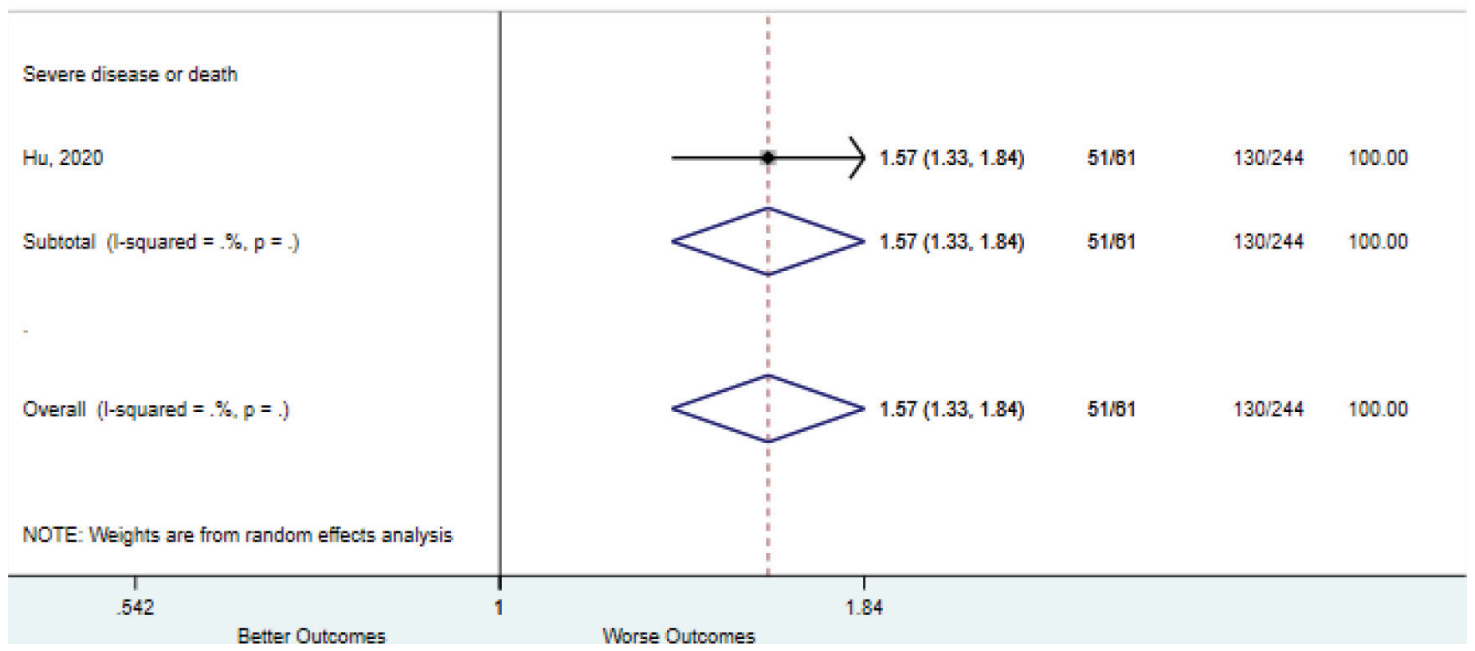

Events, Events, $\%$

RR $(95 \% \mathrm{Cl}) \quad$ Treatment Control Weight 
Male sex

Study

Events, Events, \%

ID

$\mathrm{RR}(95 \% \mathrm{Cl})$

Treatment

Control

Weight

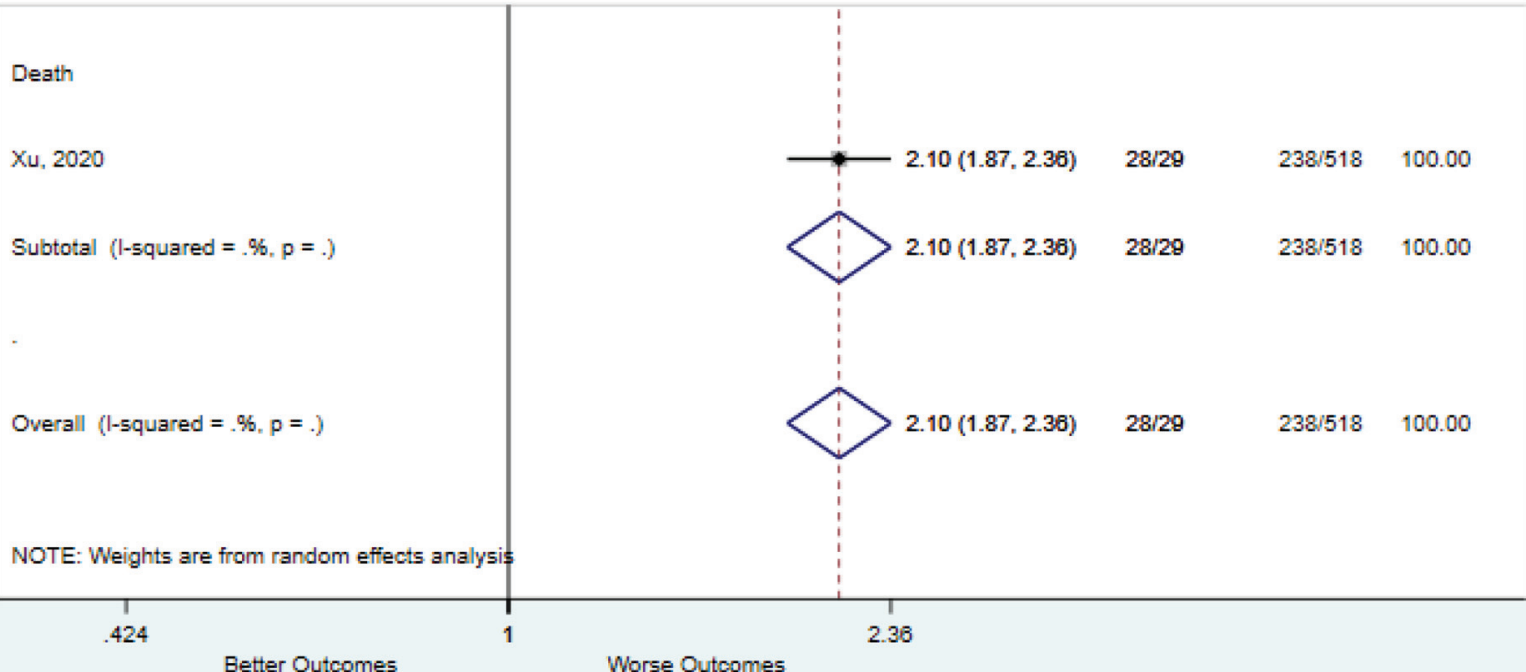

Neutrophil $>6.3$

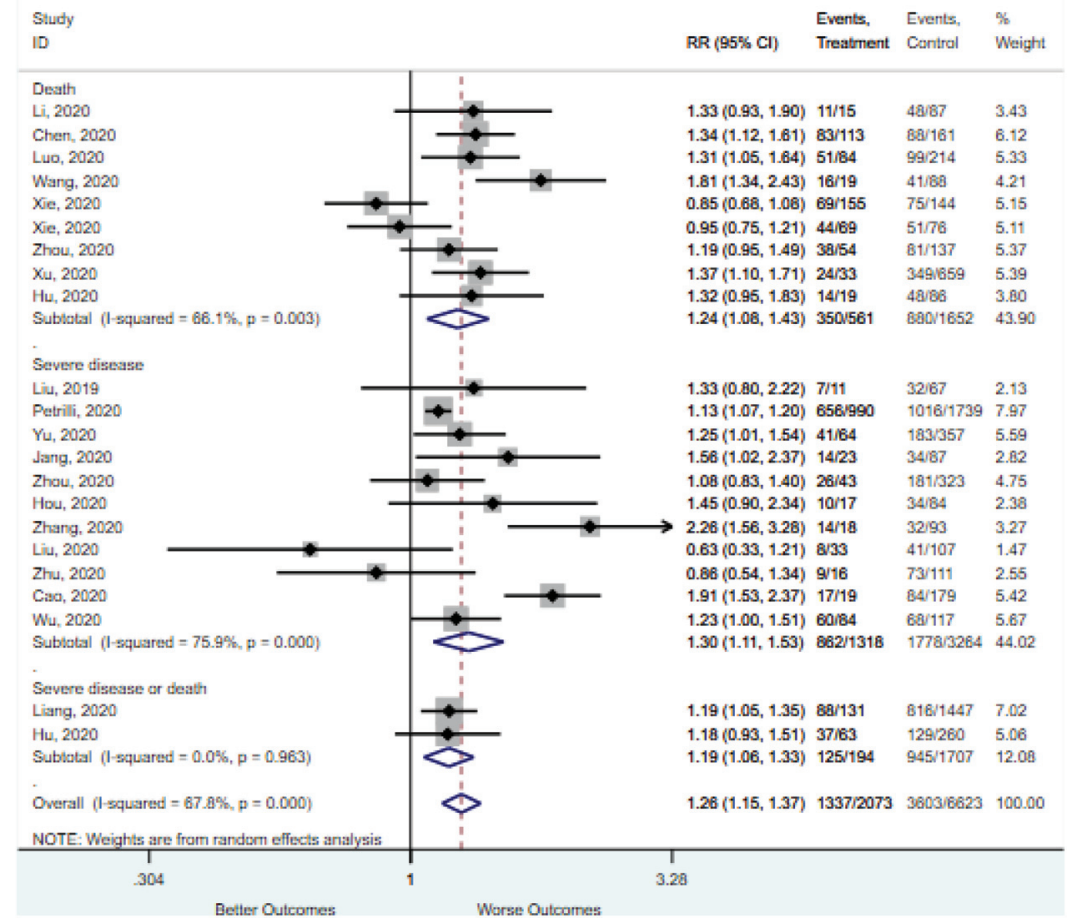


Neutrophil $>7.5$

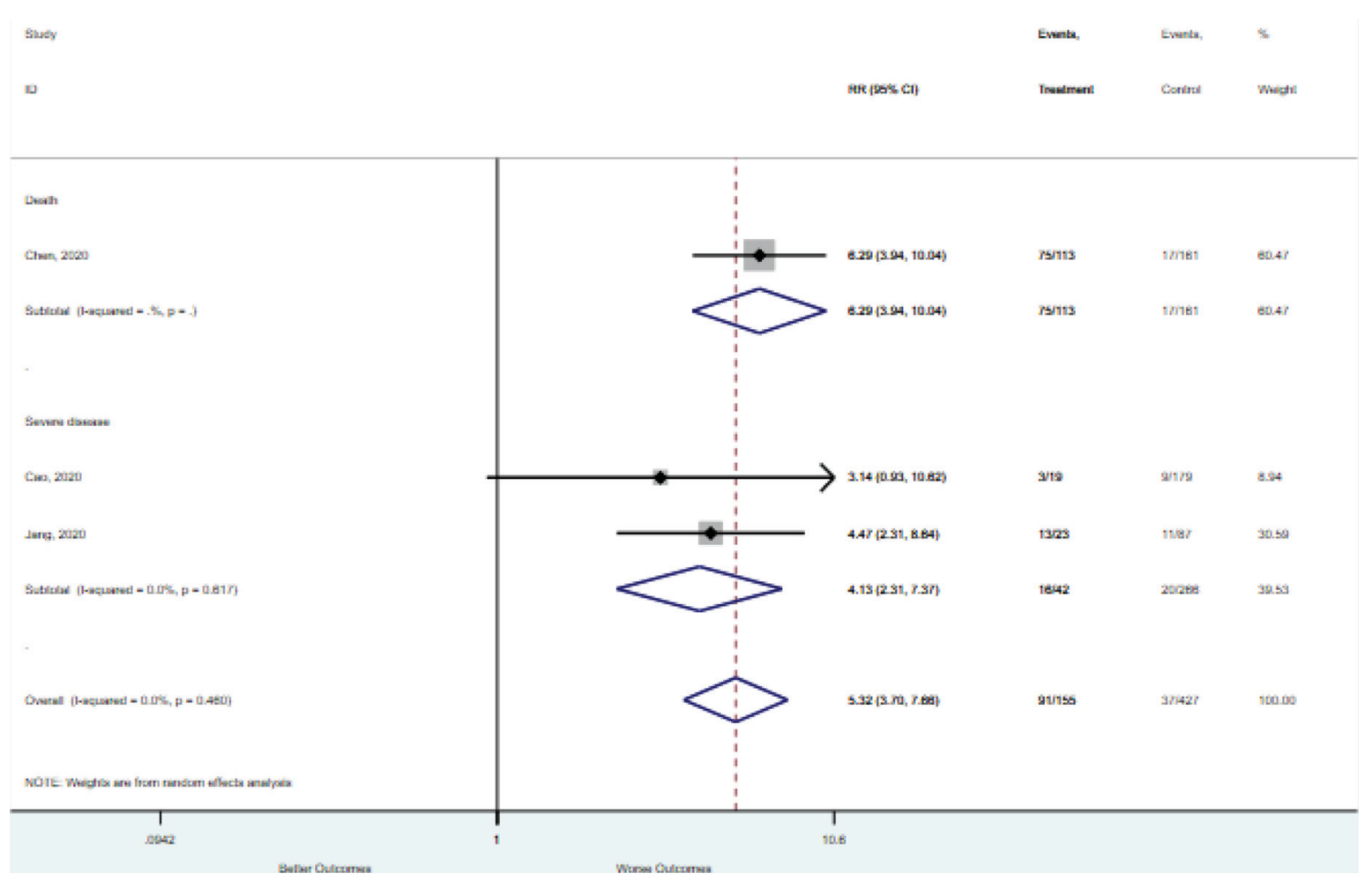


Neutrophil $<1.8$

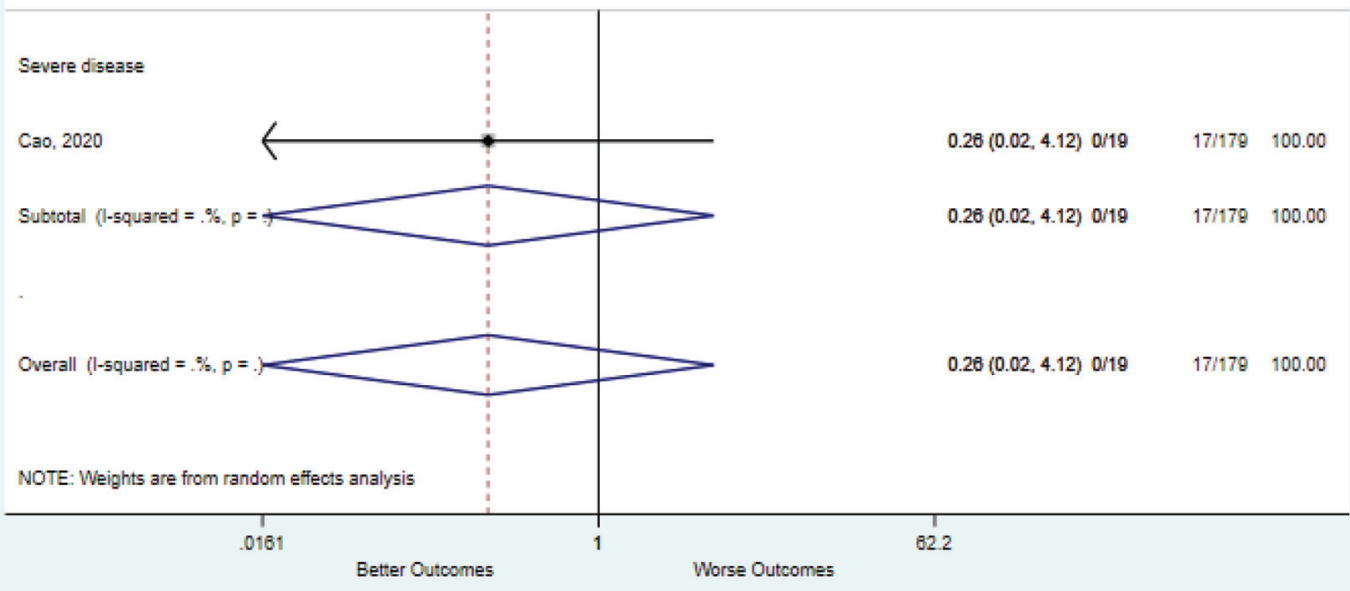


Neutrophils increased

Oxygen saturation $<88$

Study

ID

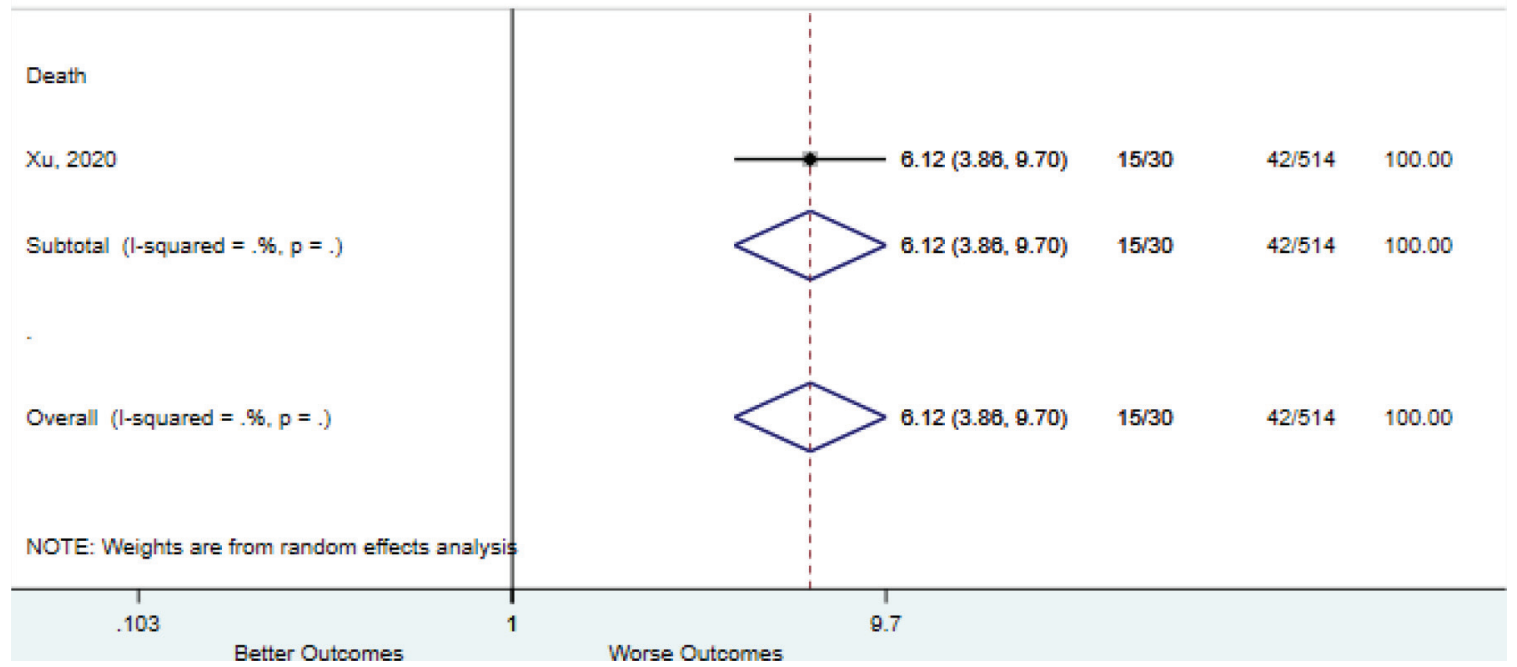

Events, Events, \%

RR $(95 \% \mathrm{Cl})$ Treatment Control Weight

$\begin{array}{lll}0.26(0.02,4.12) 0 / 19 & 17 / 179 & 100.00 \\ 0.26(0.02,4.12) 0 / 19 & 17 / 179 & 100.00\end{array}$

$0.26(0.02,4.12) 0 / 19 \quad 17 / 179 \quad 100.00$

NOTE: Weights are from random effects analysis 
Oxygen saturation $<90$ to 93

Study

ID

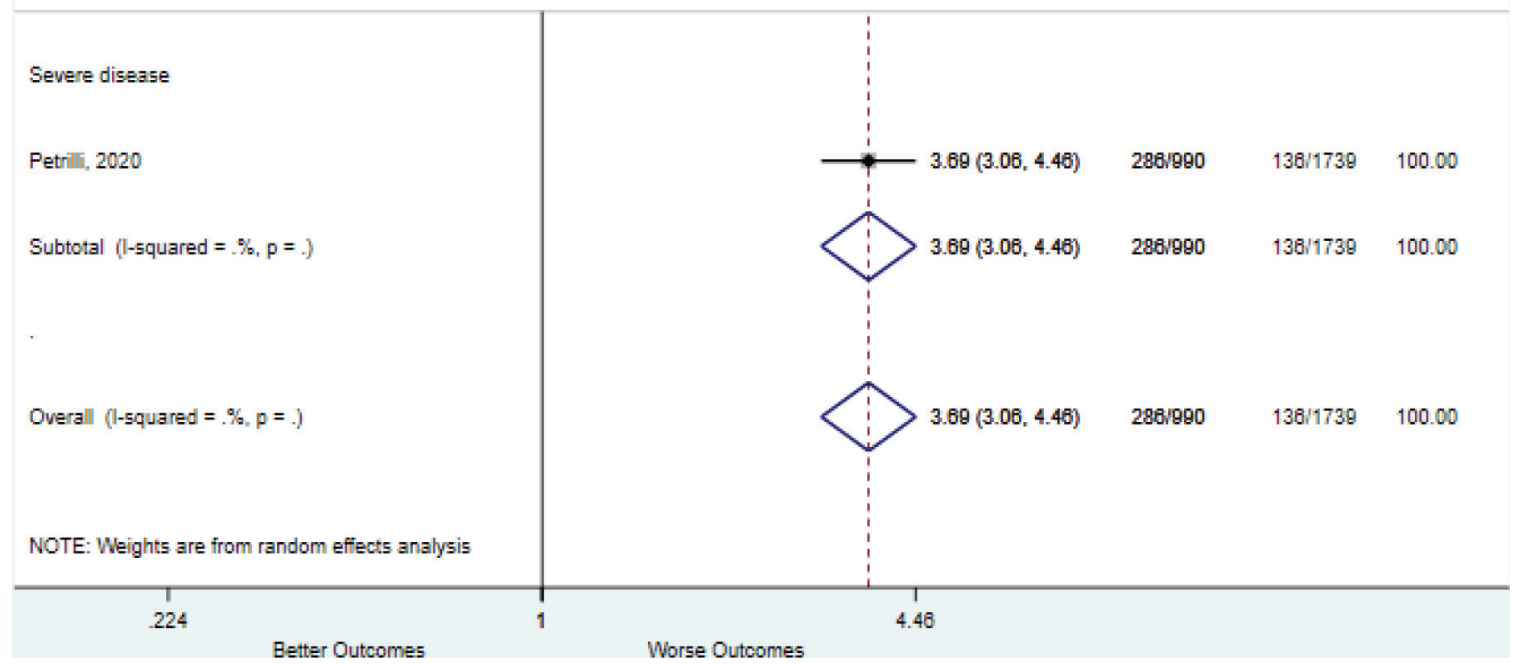

Oxygen saturation $<96$

Study

ID

Chen, 2020

Xie, 2020

Xie, 2020

Subtotal (l-squared $=0.0 \%, p=0.648)$

Overall (l-squared $=0.0 \%, p=0.648$ )

NOTE: Weights are from random effects analysis

0436


Procalcitonin $0.05-0.5$

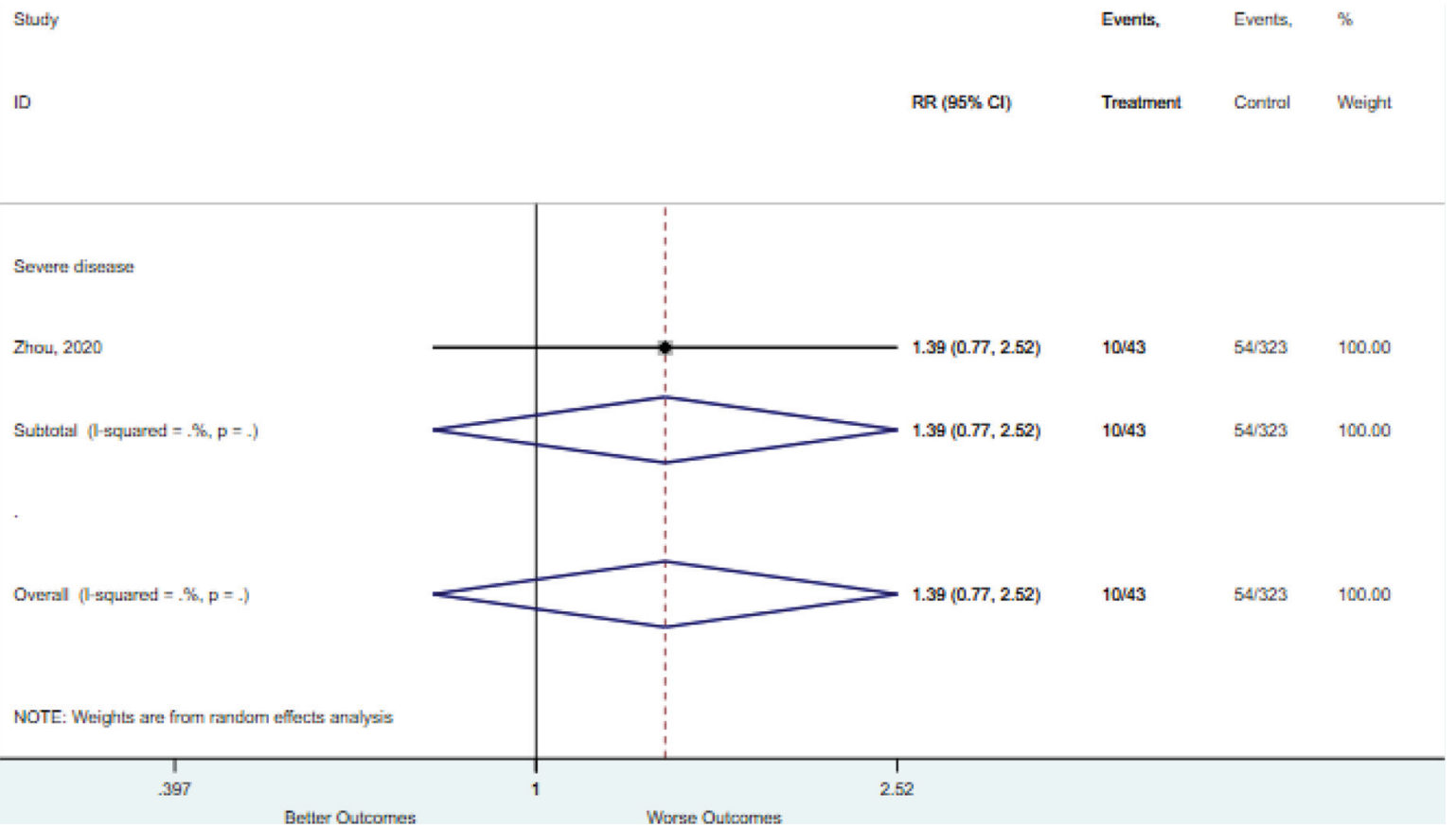

Procalcitonin 0.5-2.0

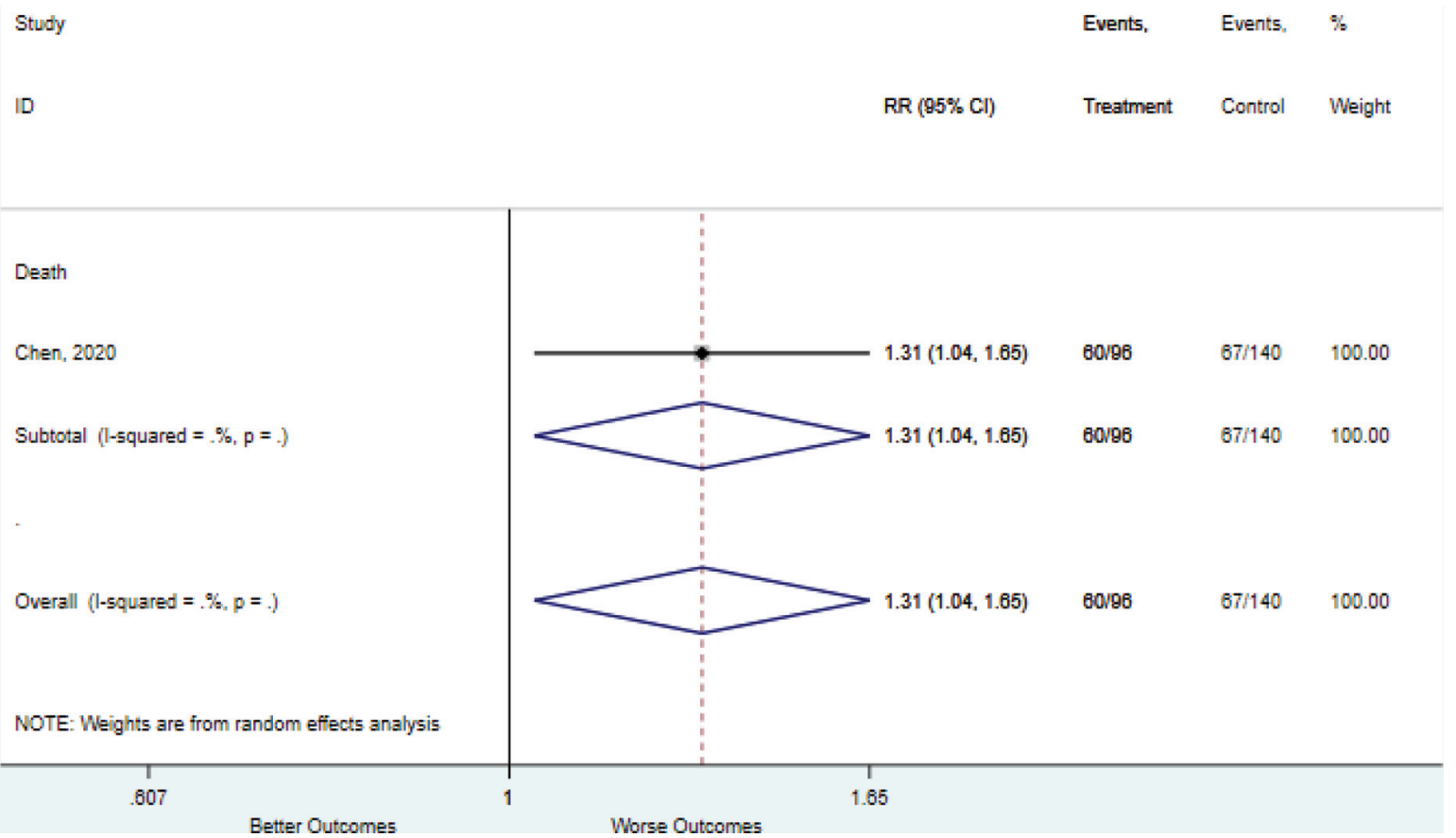


Procalcitonin $\geq 0.1$ to 0.25

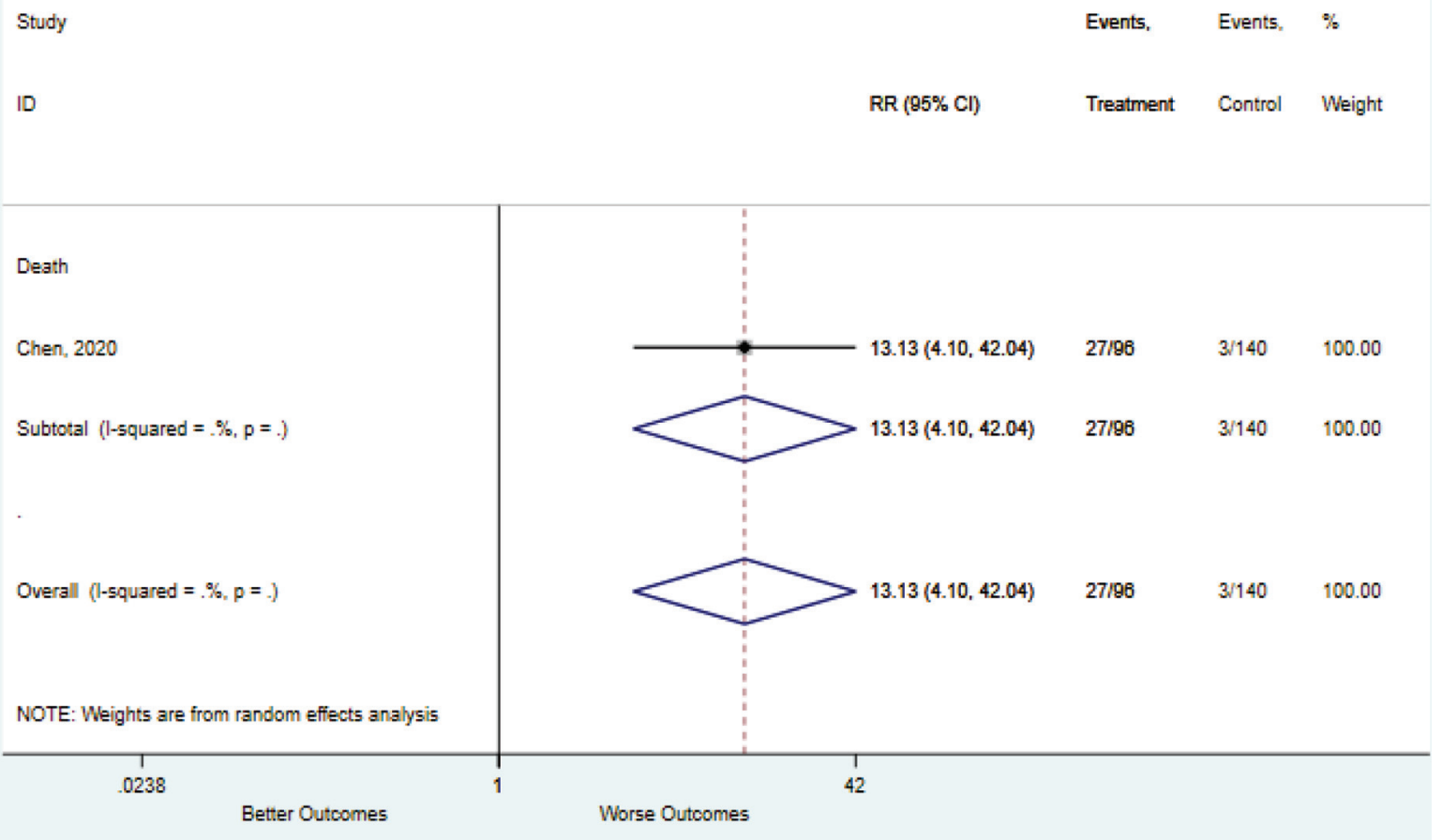

Procalcitonin $\geq 0.25$ to 0.5

Study
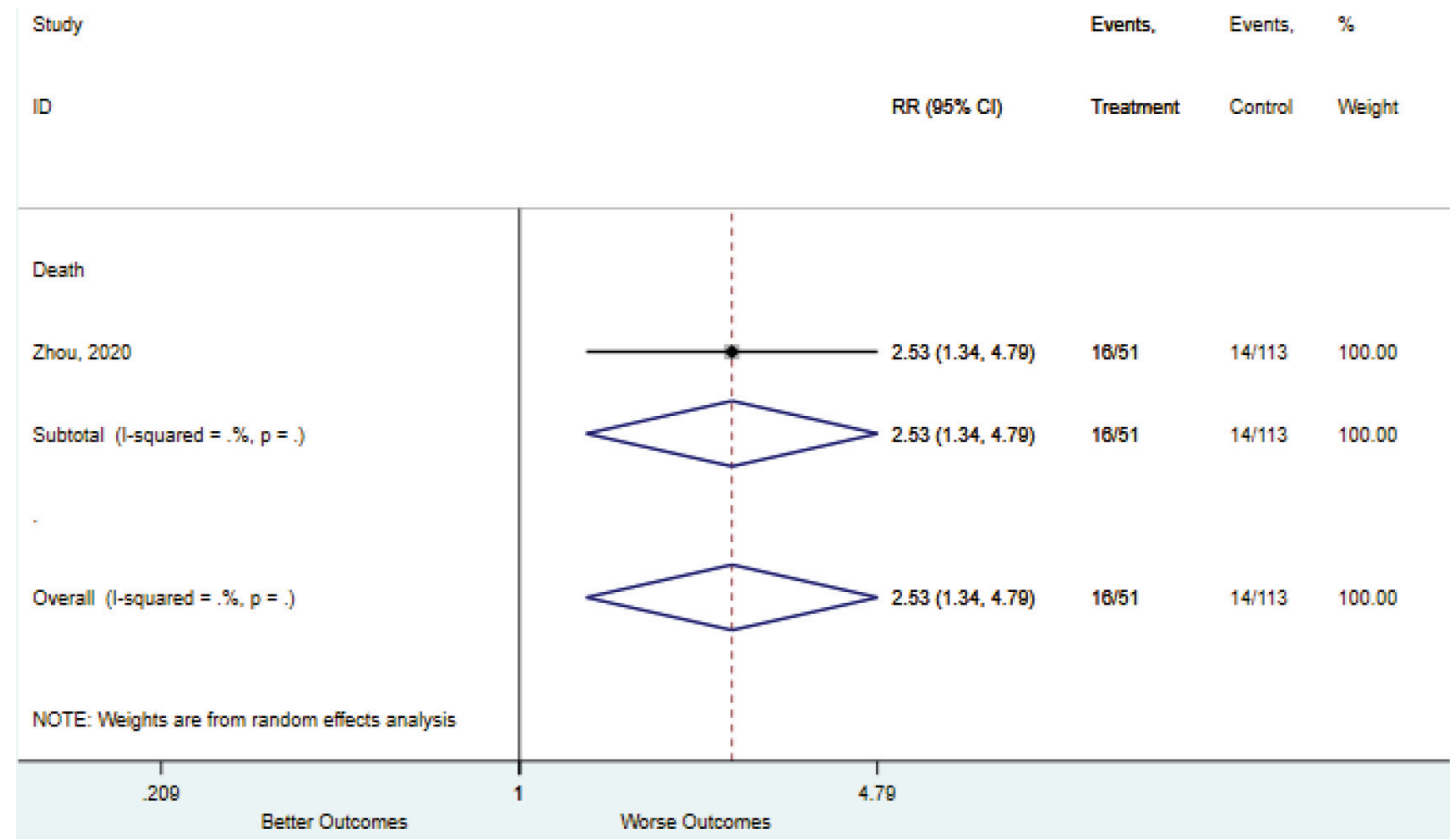
Procalcitonin $\geq 2.0$

Procalcitonin $>0.05$

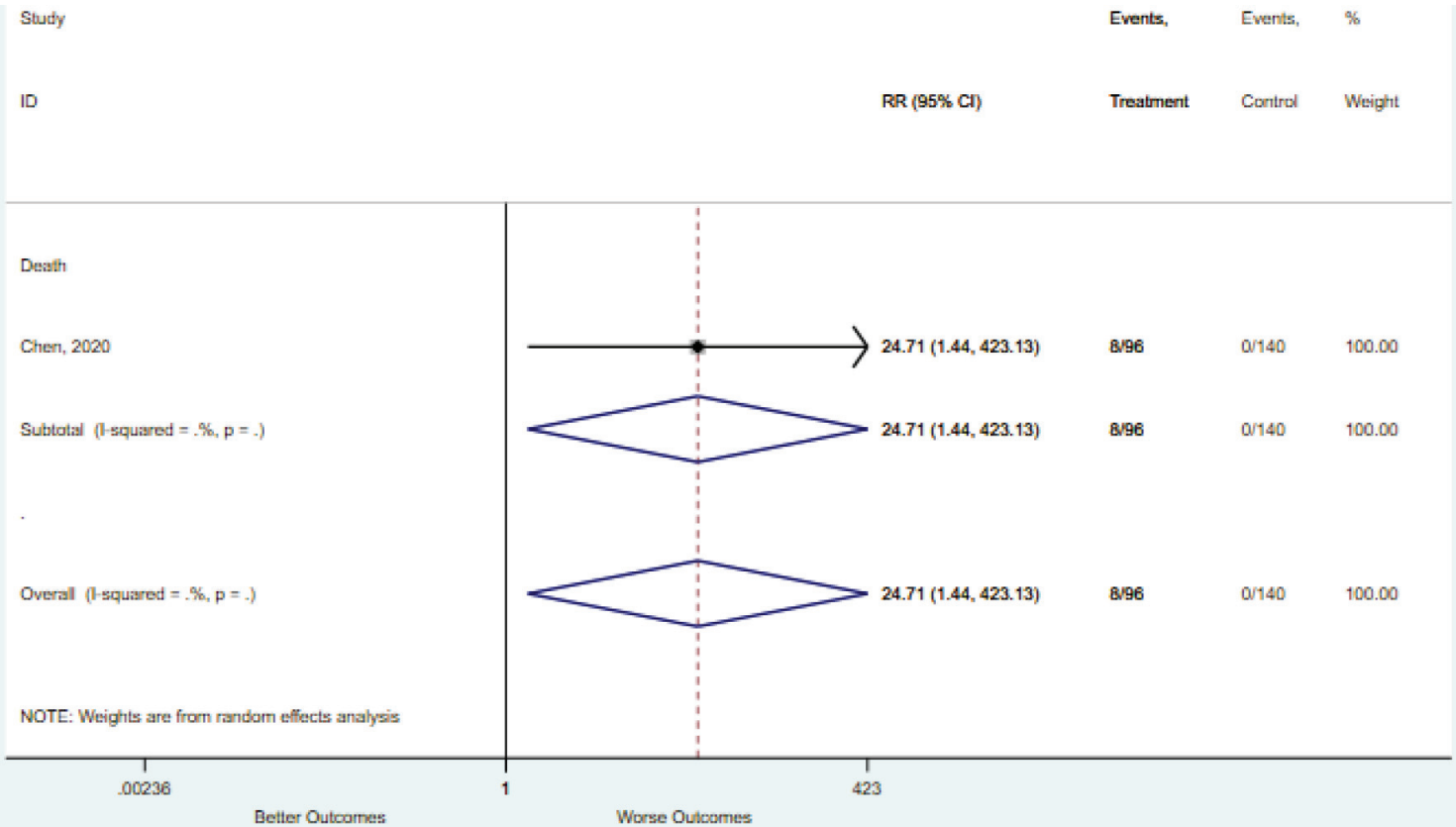


Procalcitonin increased

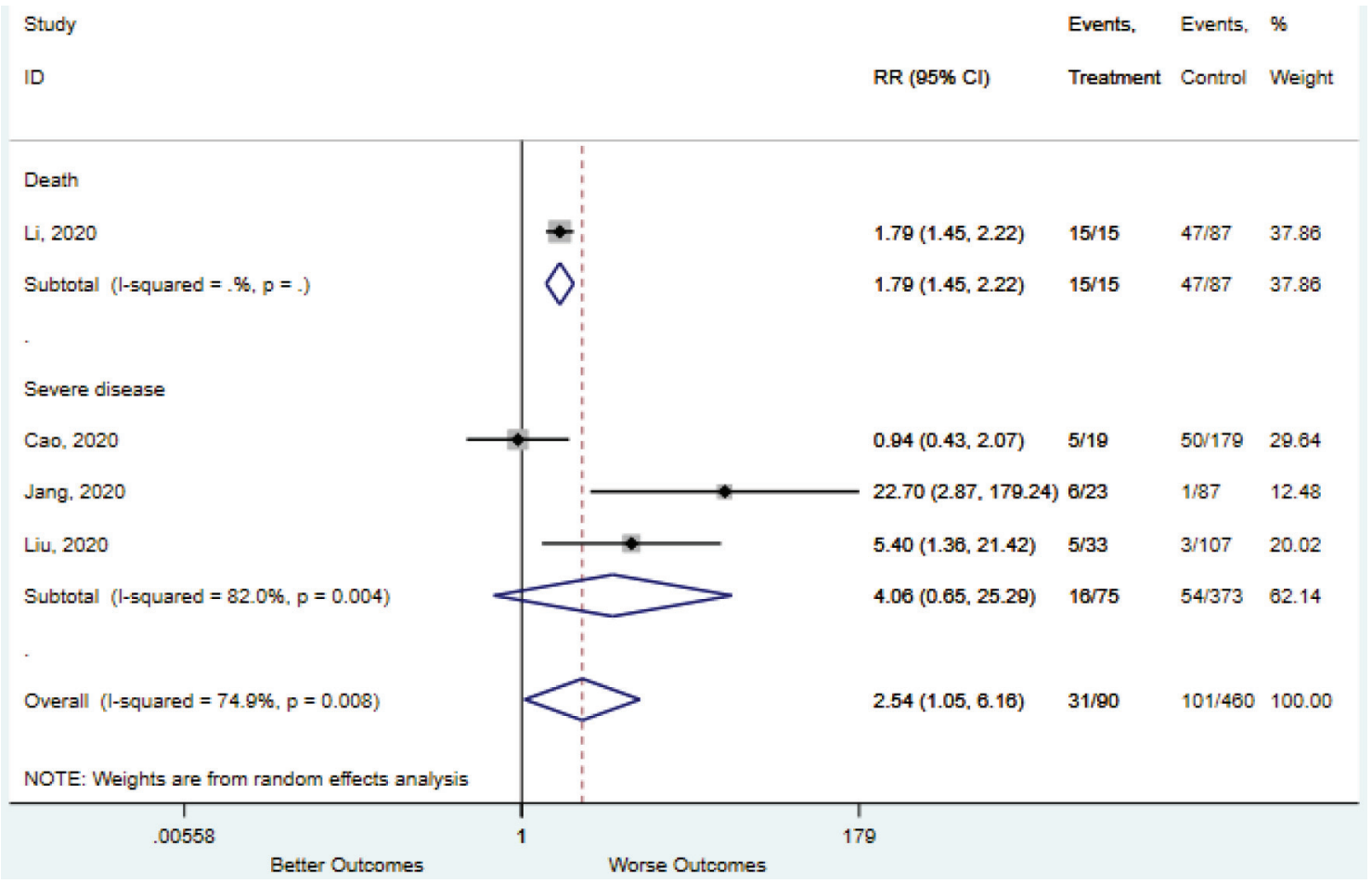

Procalcitonin $<0.1$

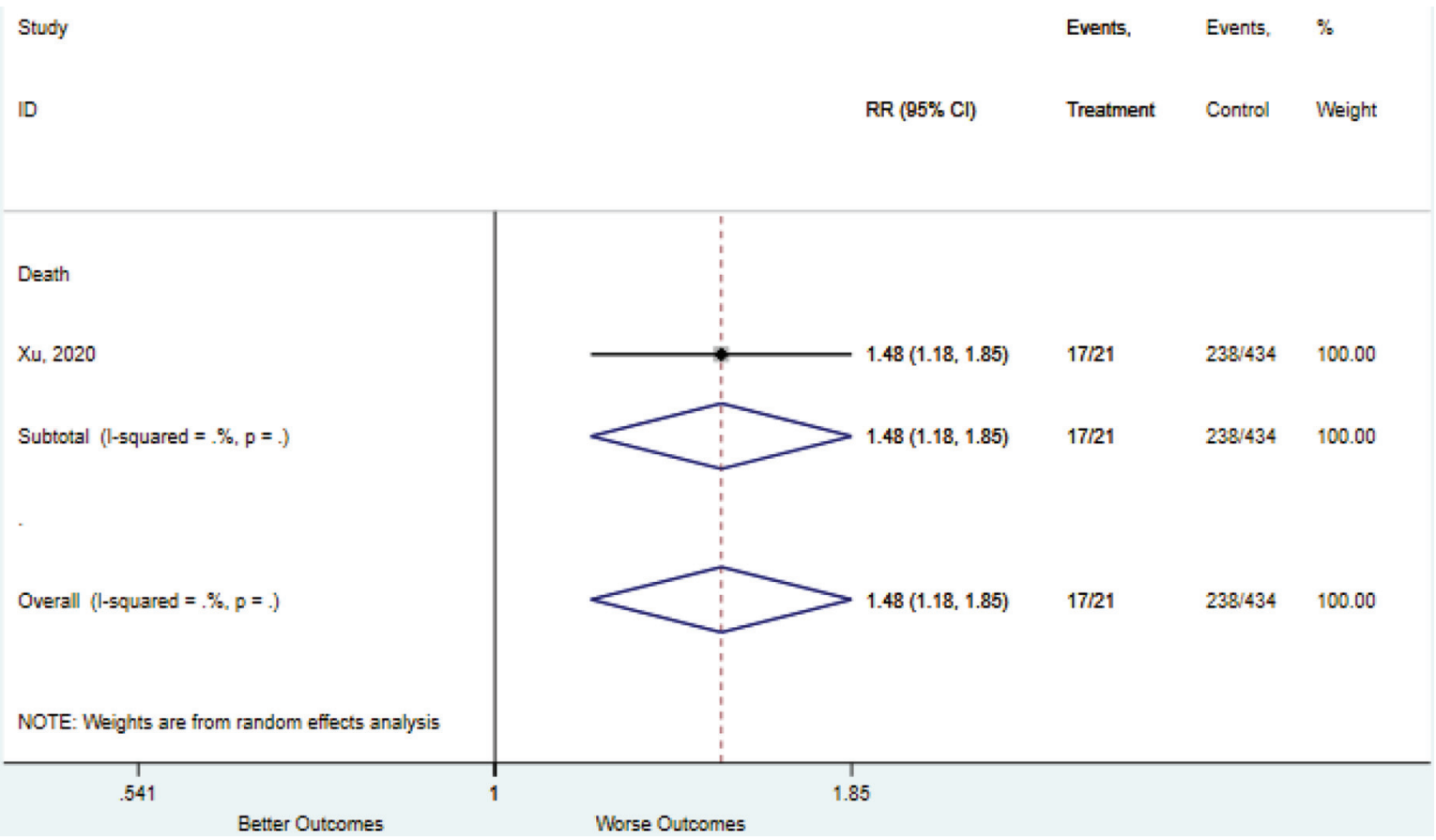


Respiratory rate 24-30

Study

ID

NOTE: Weights are from random effects arlalysis

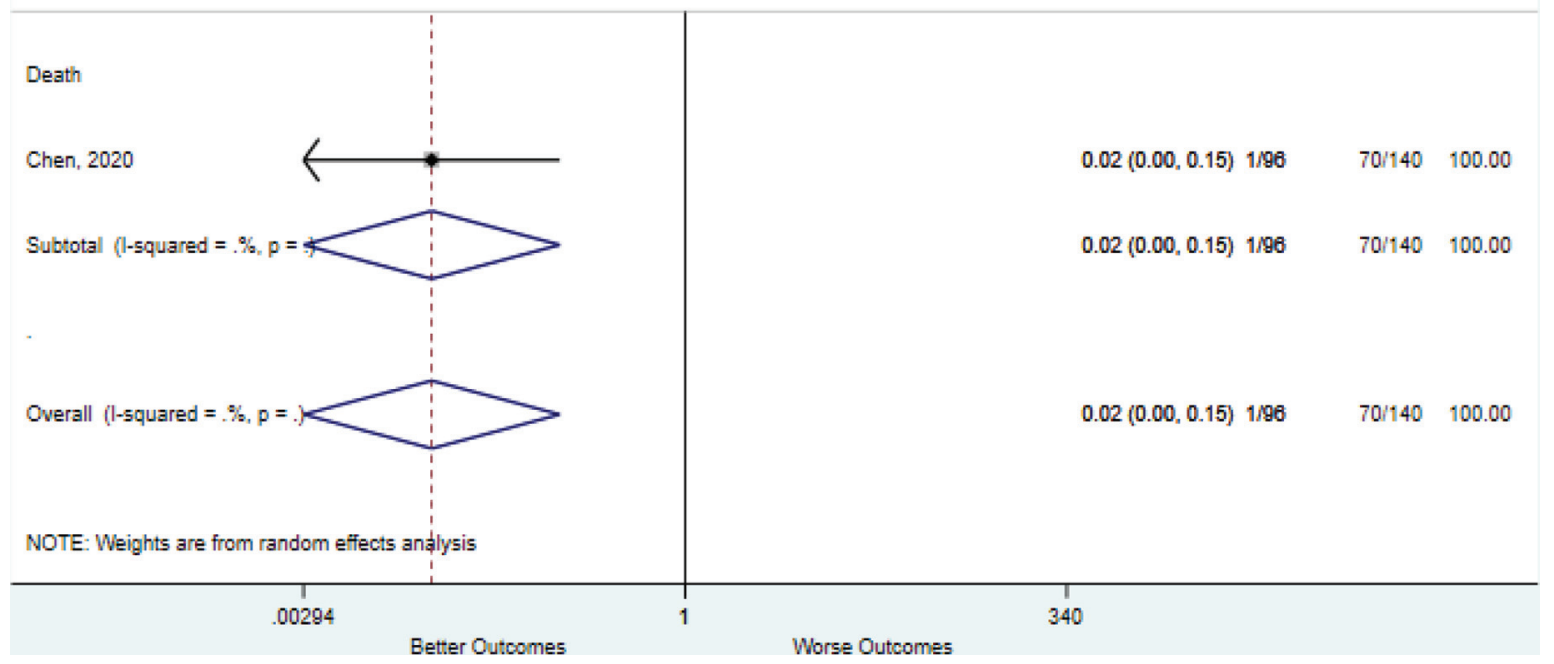


Respiratory rate $>20$ to 30

Respiratory rate $<24$

Study

ID

$\mathrm{RR}(8.5 \% \mathrm{Cl})$

Events, Events, \%

Treatment Control Weight

\section{Desth}

Chen, 2020

Subtotal (l-squared $=\%, p=$.

Overall (l-squared $=. \%, p=$.)

NOTE: Weights are from random effects analysis

196

Better Outcomes

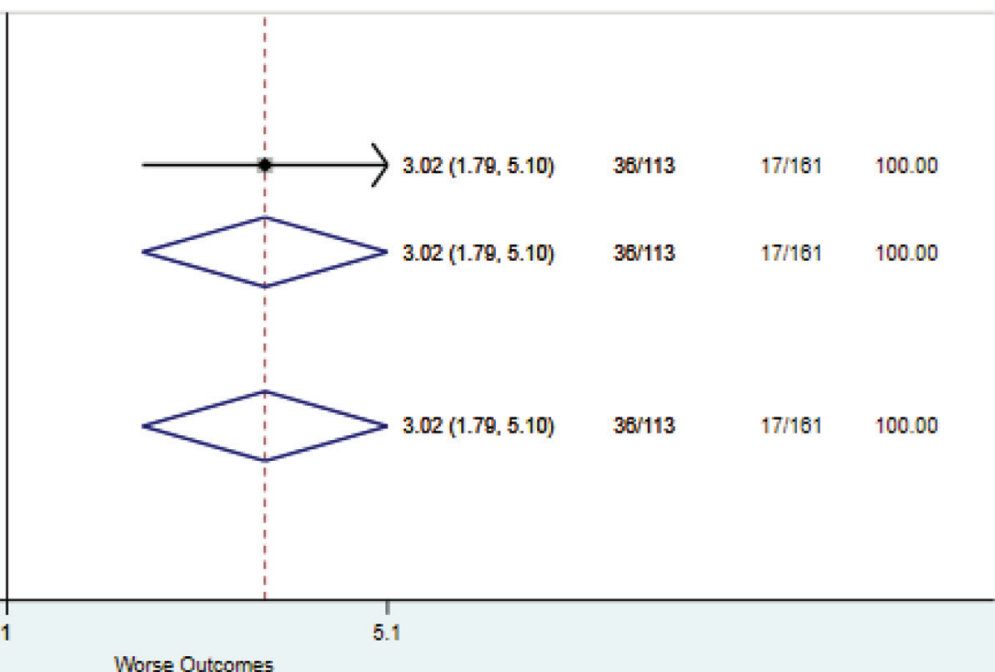

Worse Outcomes

Events, Events, \%

RR ( $95 \% \mathrm{Cl}) \quad$ Treatment Control Weight

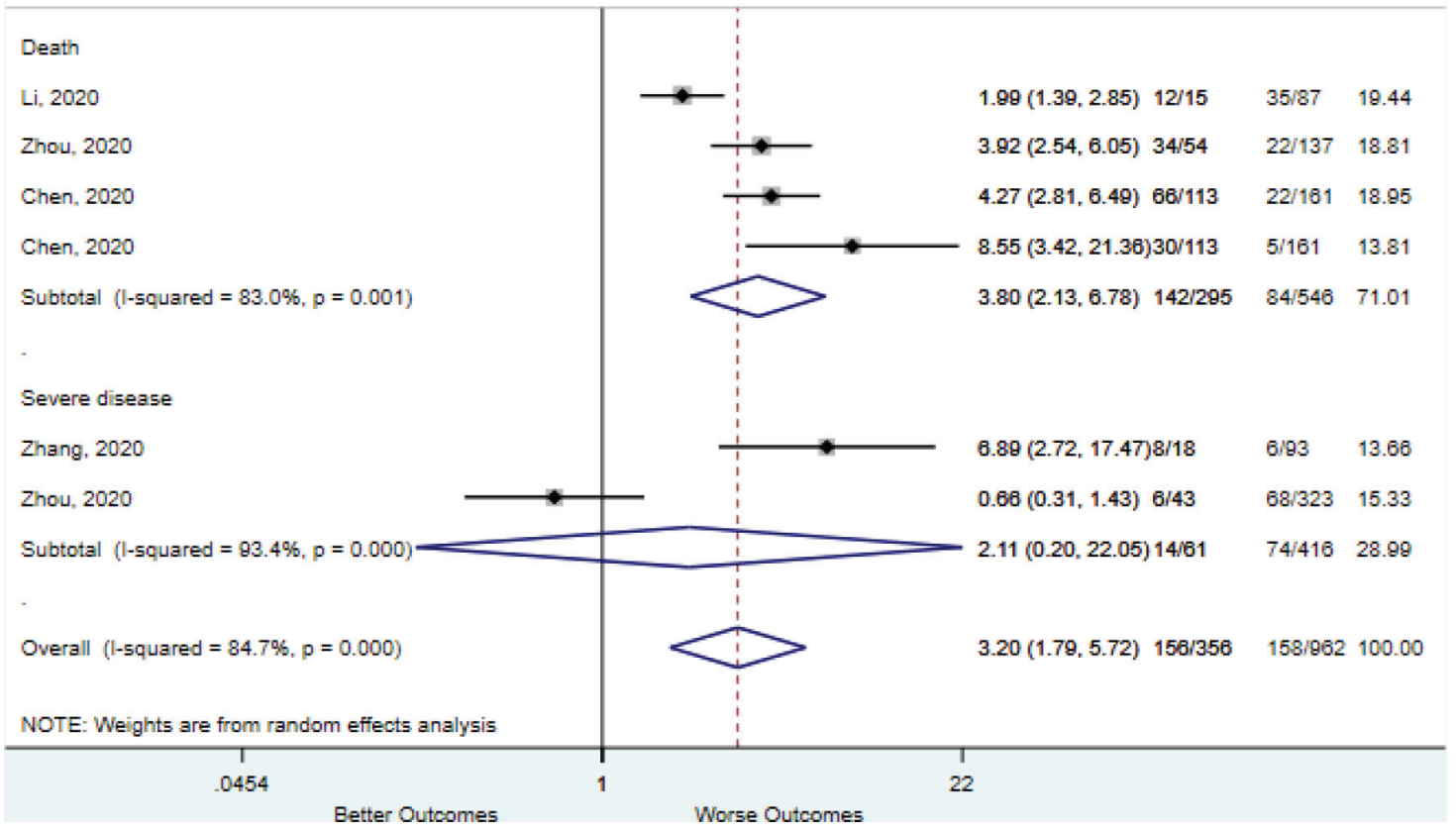


SBP 90-140

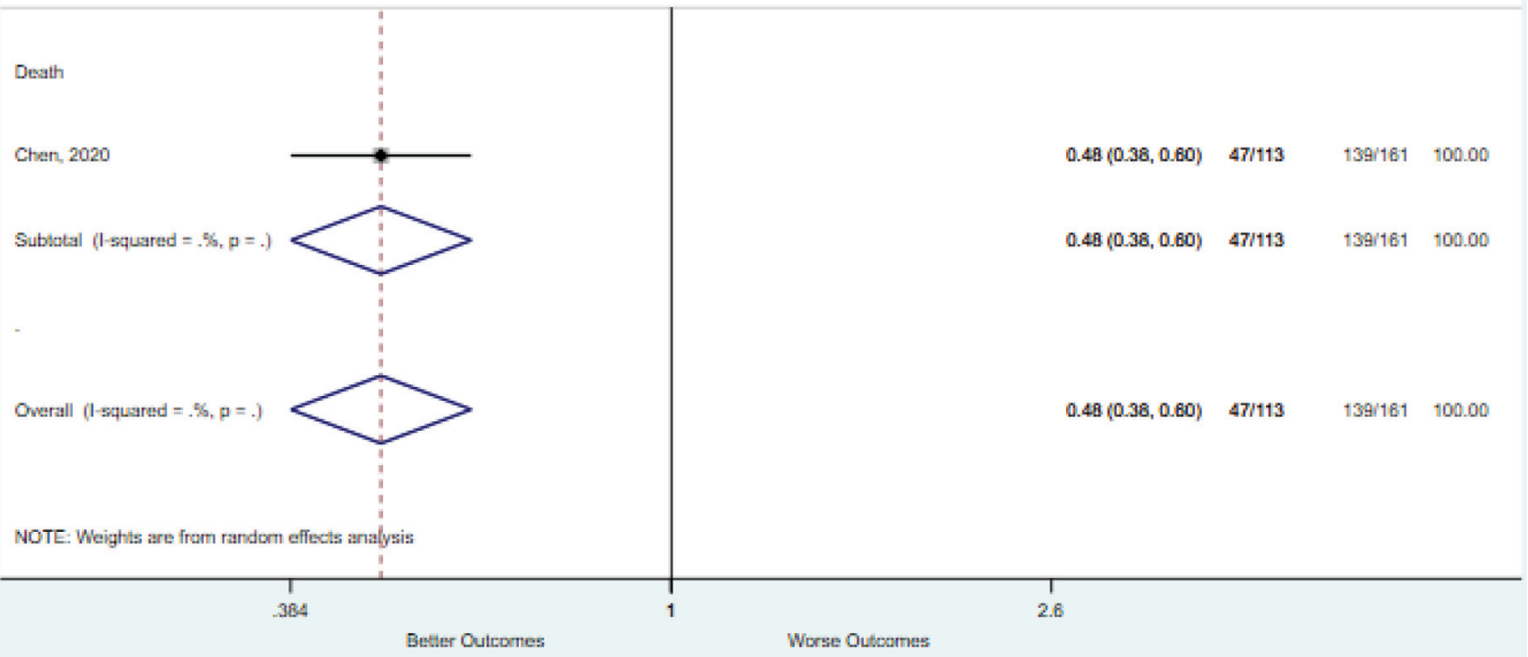

$\mathrm{SBP} \geq 110$

Study

ID

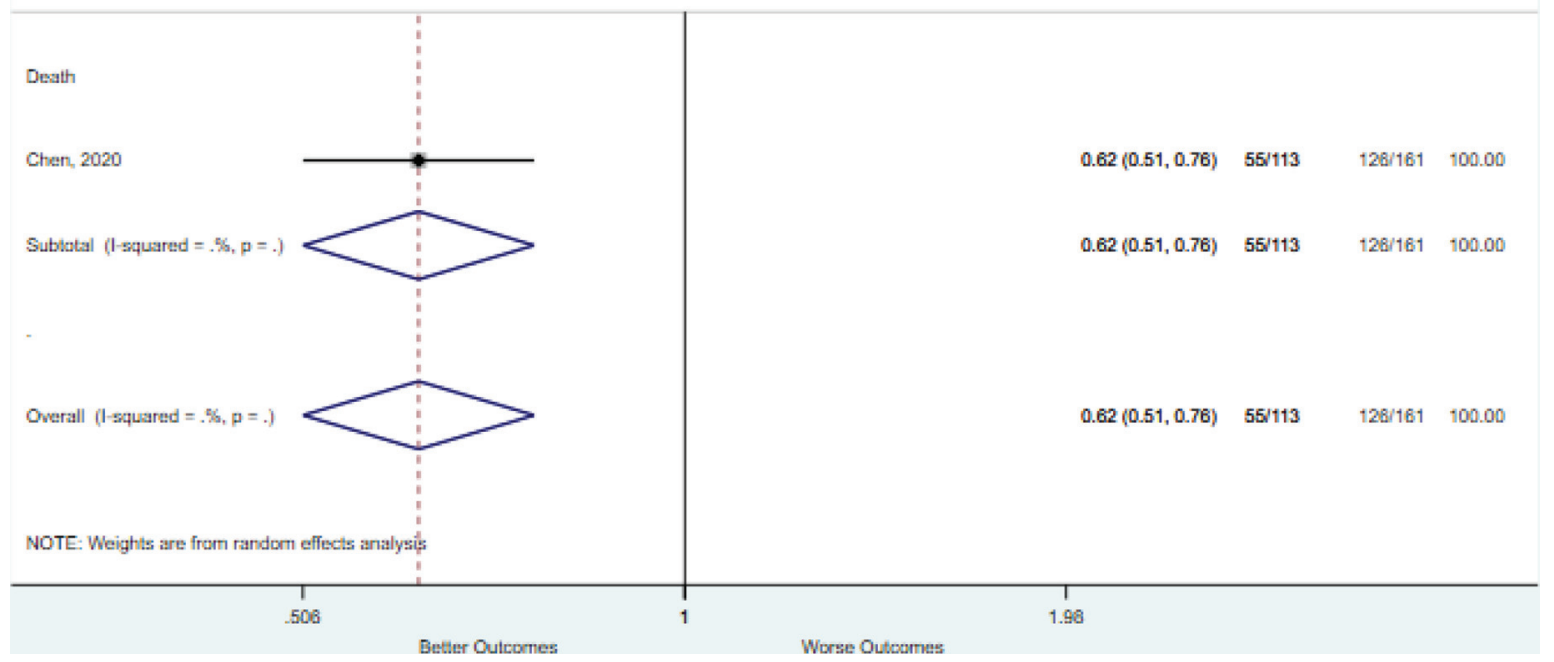

Events, Events, \%

RR $(95 \% \mathrm{Cl}) \quad$ Tresiment Contral Weight 


$$
\mathrm{SBP} \geq 140
$$

Events, Events, \%

ID

RR $(95 \% \mathrm{Cl}) \quad$ Treatment Control Weight

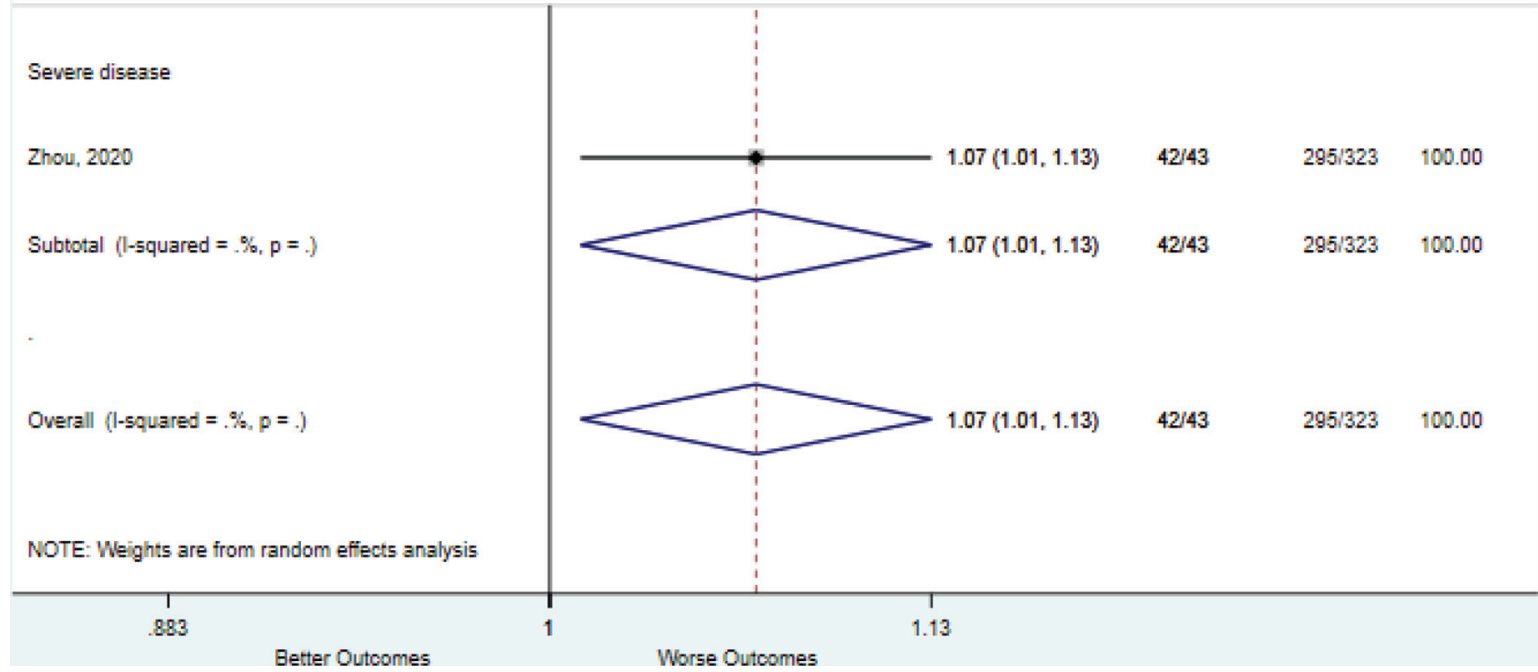

$\mathrm{SBP}<90$

Study

ID

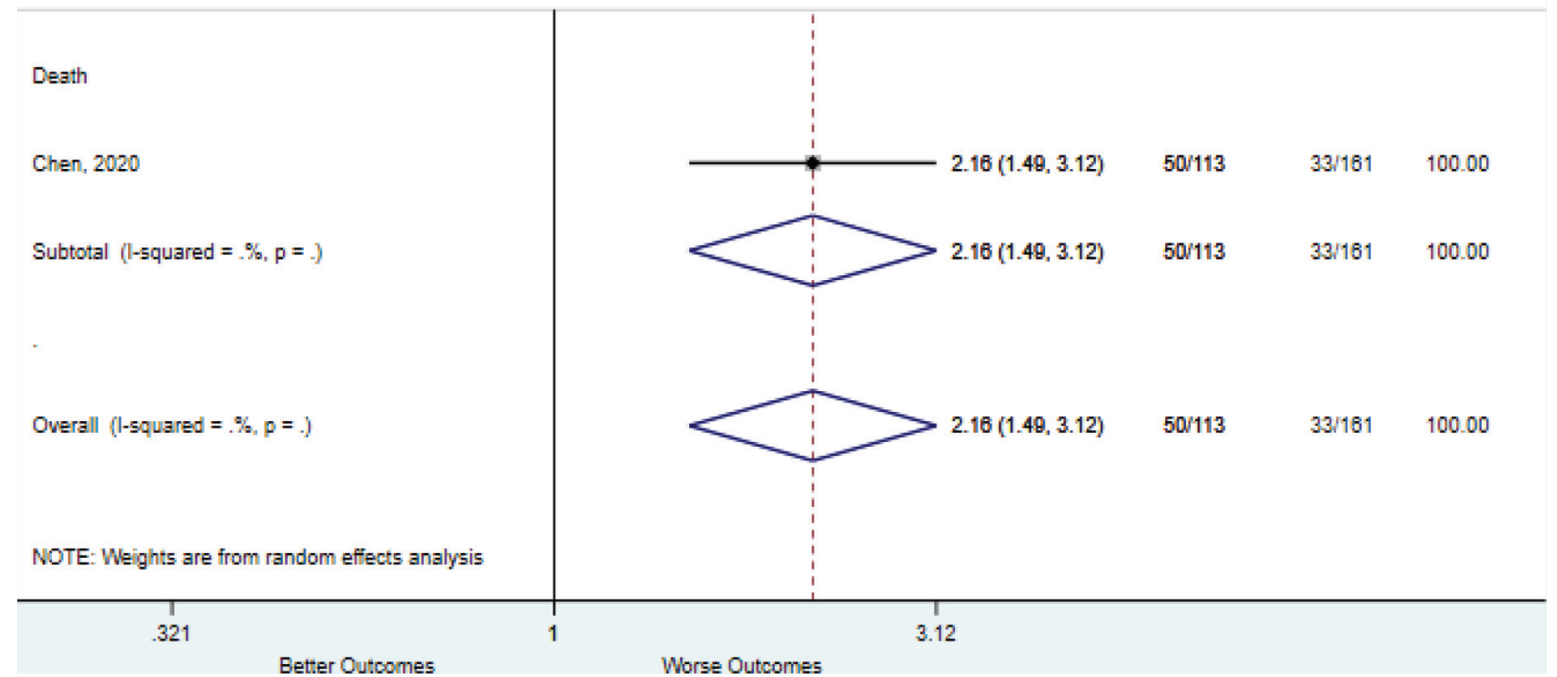

Events, Events, \%

RR ( $85 \% \mathrm{Cl}) \quad$ Treatment Control Weight 
Troponin $>34.2$

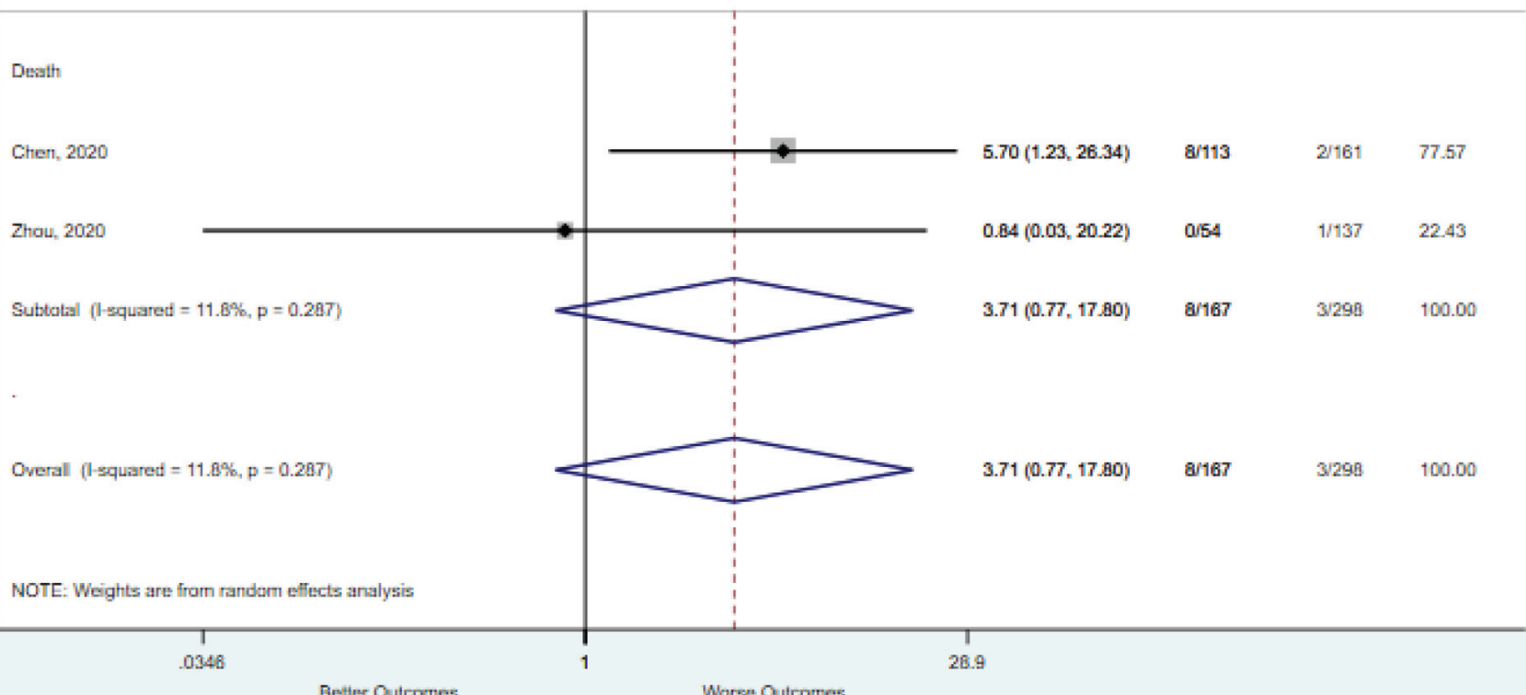

WBC 4-10
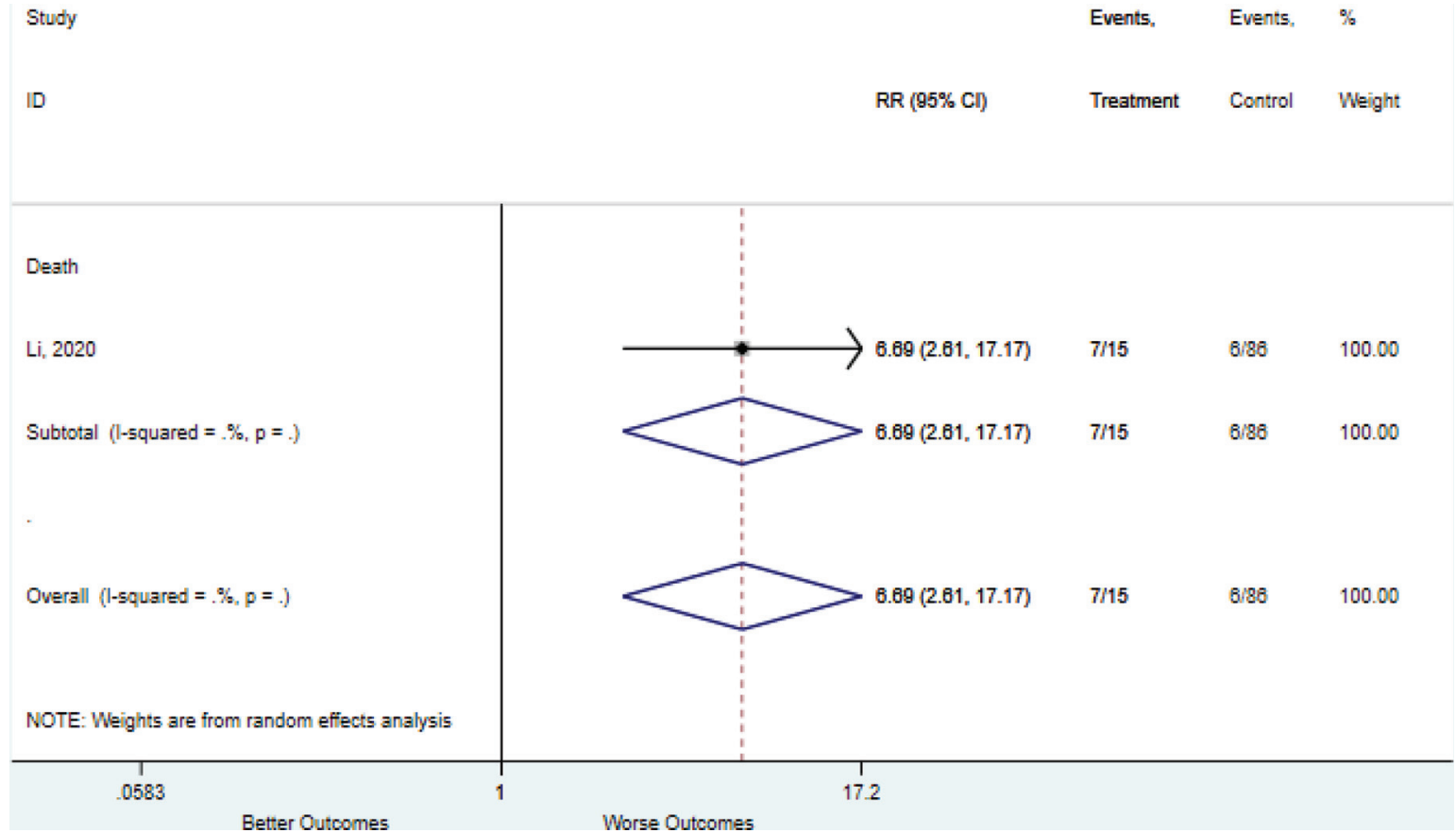
$\mathrm{WBC} \geq 4$

study

Emants, Evants, $\mathrm{W}$

ID

RR (GG\% C) Tneatmant Canter Wolght

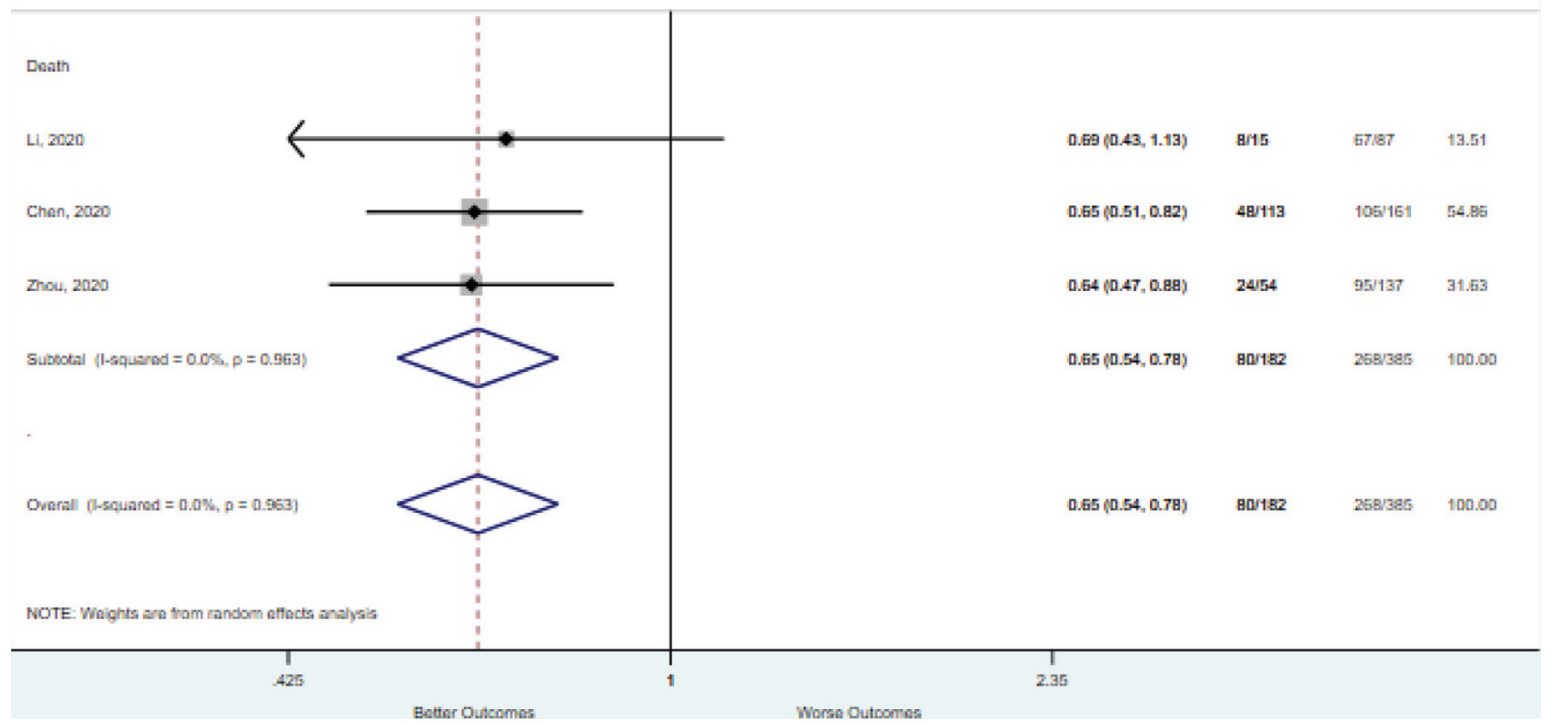

$\mathrm{WBC} \geq 9.5$ to 10

Study

ID

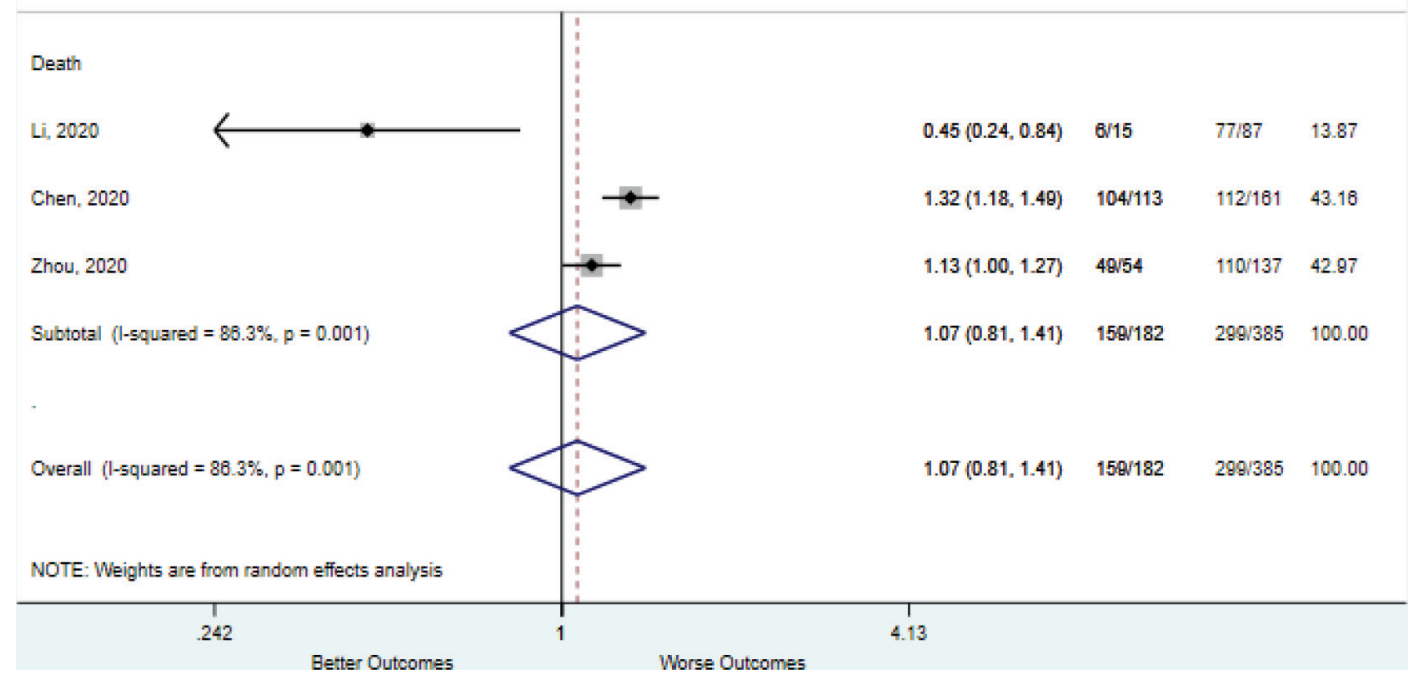

Events, Events, \%

$\mathrm{RR}(95 \% \mathrm{Cl}) \quad$ Treatment Control Weight 
WBC increased

WBC $<3.5$ to 4.0

$\mathrm{RR}(95 \% \mathrm{Cl})$

Events, Events, \%

ID

Treatment Control Weight

Death

Li, 2020

Chen, 2020

Zhou, 2020

Subtotal (1-squared $=74.6 \%, p=0.019$ )

Severe disease

Cao, 2020

Jang, 2020

Subtotal (l-squared $=0.0 \%, p=0.412$ )

Severe disease or death

$\mathrm{Hu}, 2020$

Subtotal (l-squared $=. \%, p=$.)

$3.48(1.49,8.15) \quad 6 / 15$

$10 / 87 \quad 17.22$

$13.30(5.93,29.80) 56 / 113 \quad 6 / 161 \quad 18.21$

$4.23(2.42,7.38) \quad 25 / 54 \quad 15 / 137 \quad 24.82$

$5.73(2.48,13.27) \quad 87 / 182 \quad 31 / 385 \quad 60.25$

Overall (l-squared $=46.8 \%, p=0.094$ )

NOTE: Weights are from random effects analysis

Study

ID

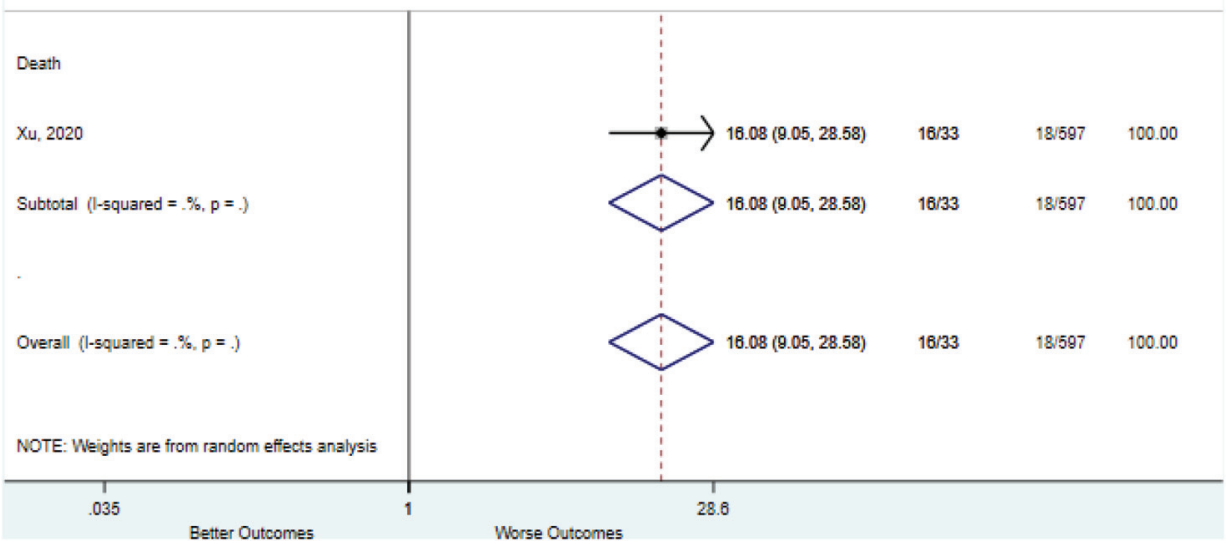



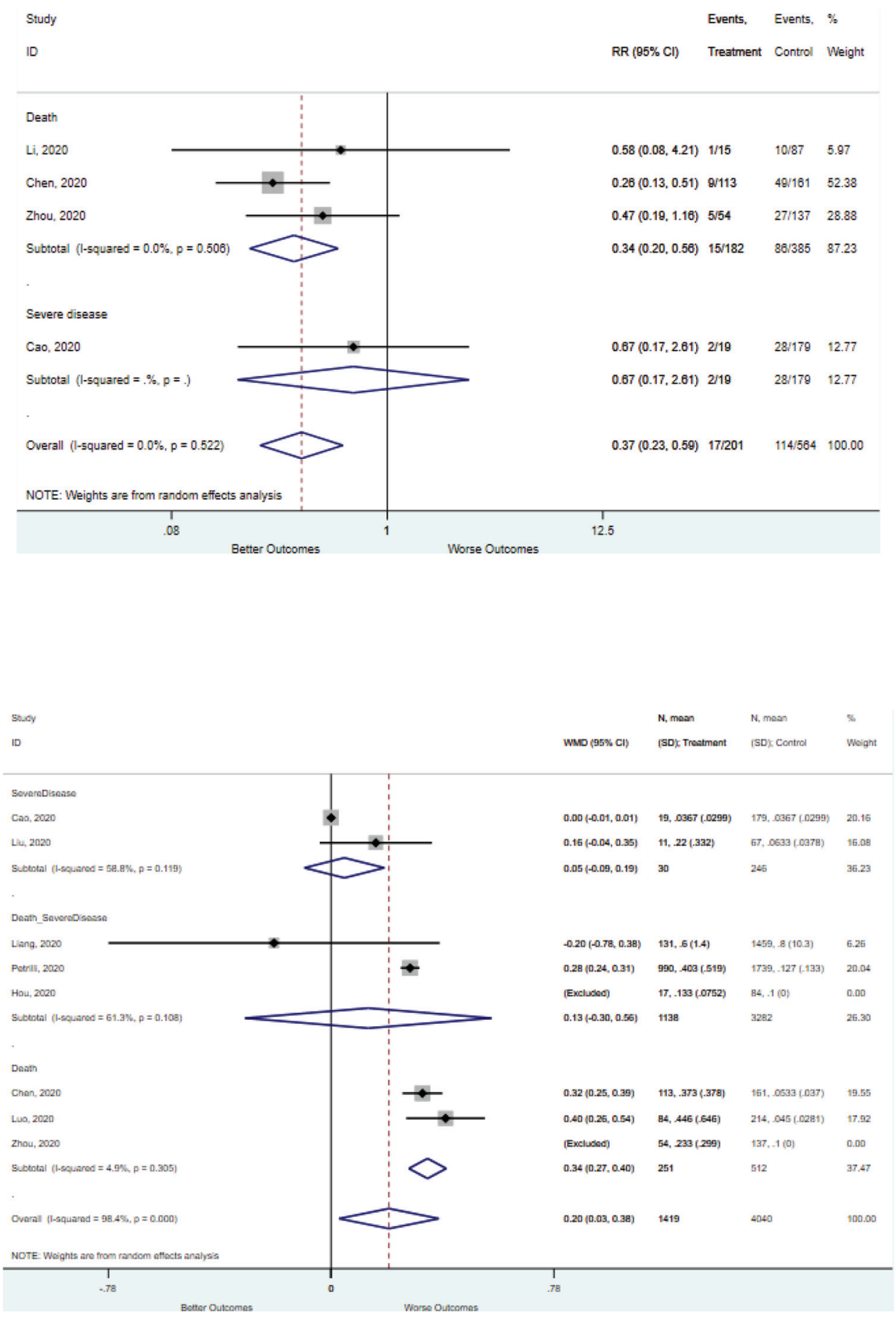

$\mathrm{COPD}=$ chronic obstructive pulmonary disease; CRP, c-reactive protein; LDH, lactate dehydrogenase; WBC, white blood count; SBP, systolic blood pressure. 


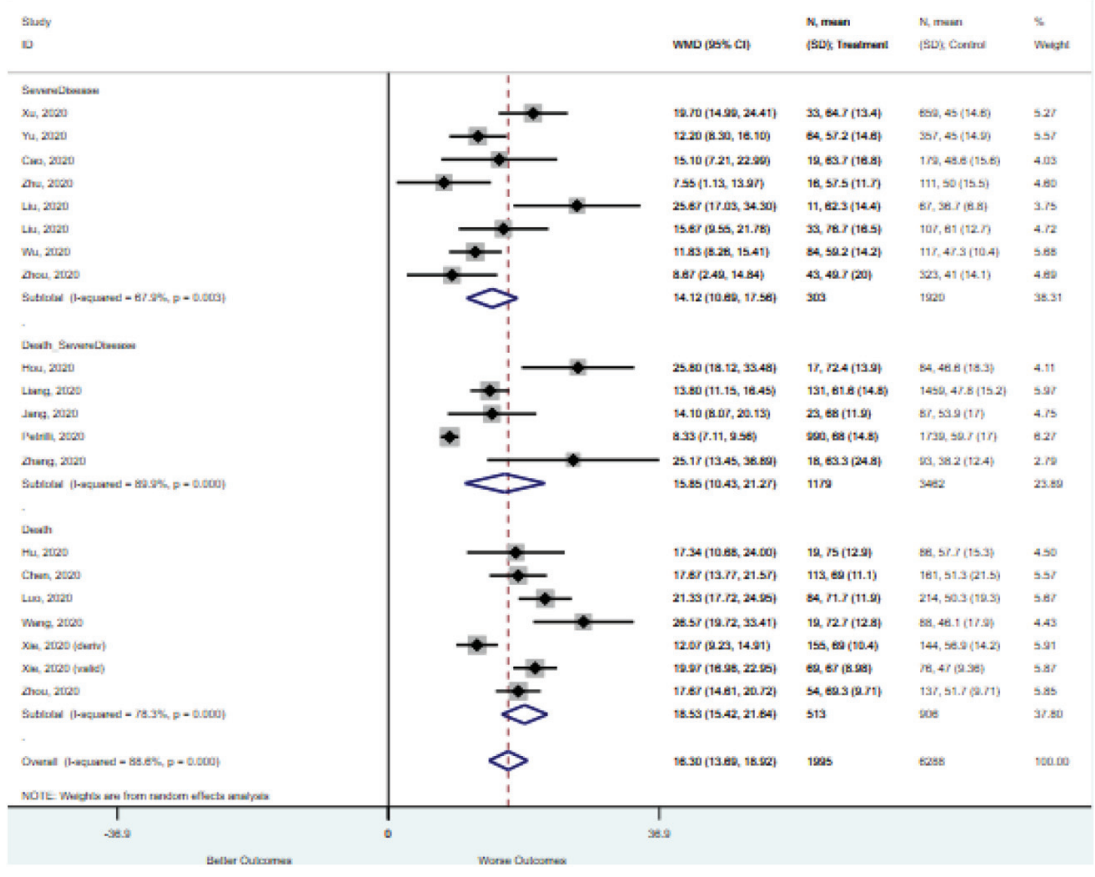

CRP

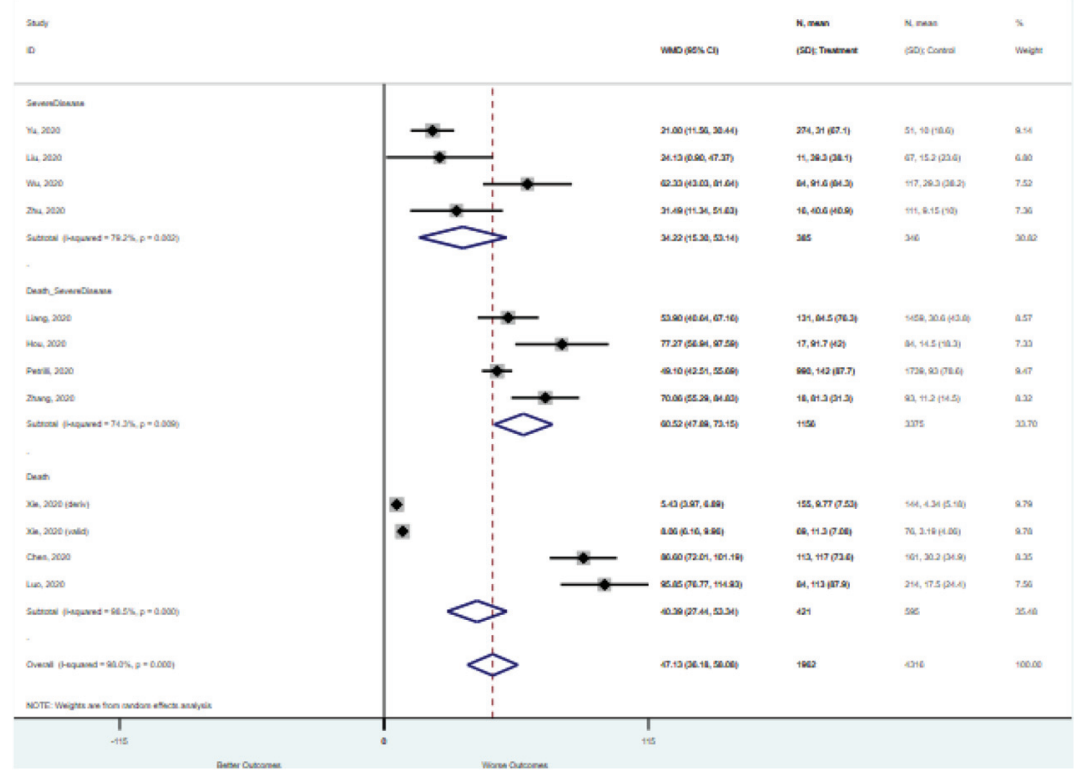


D-dimer

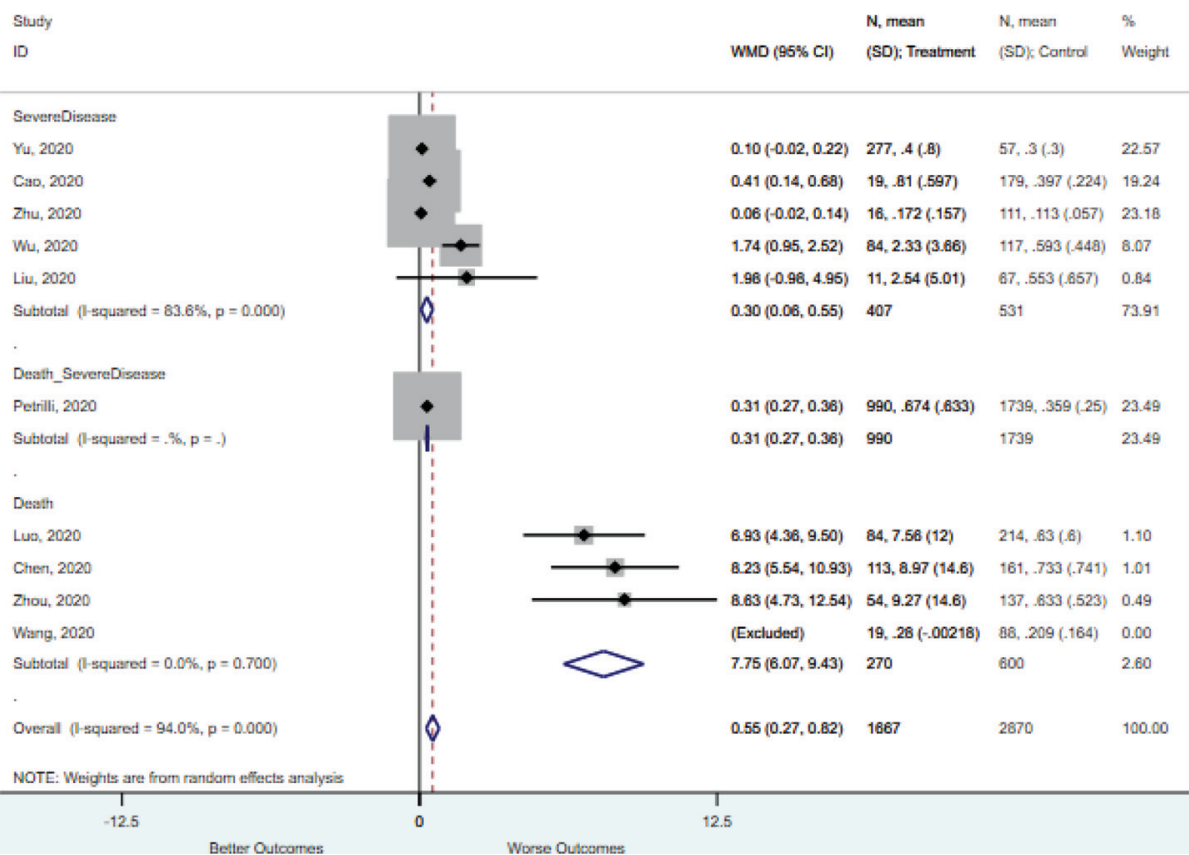

Heart rate

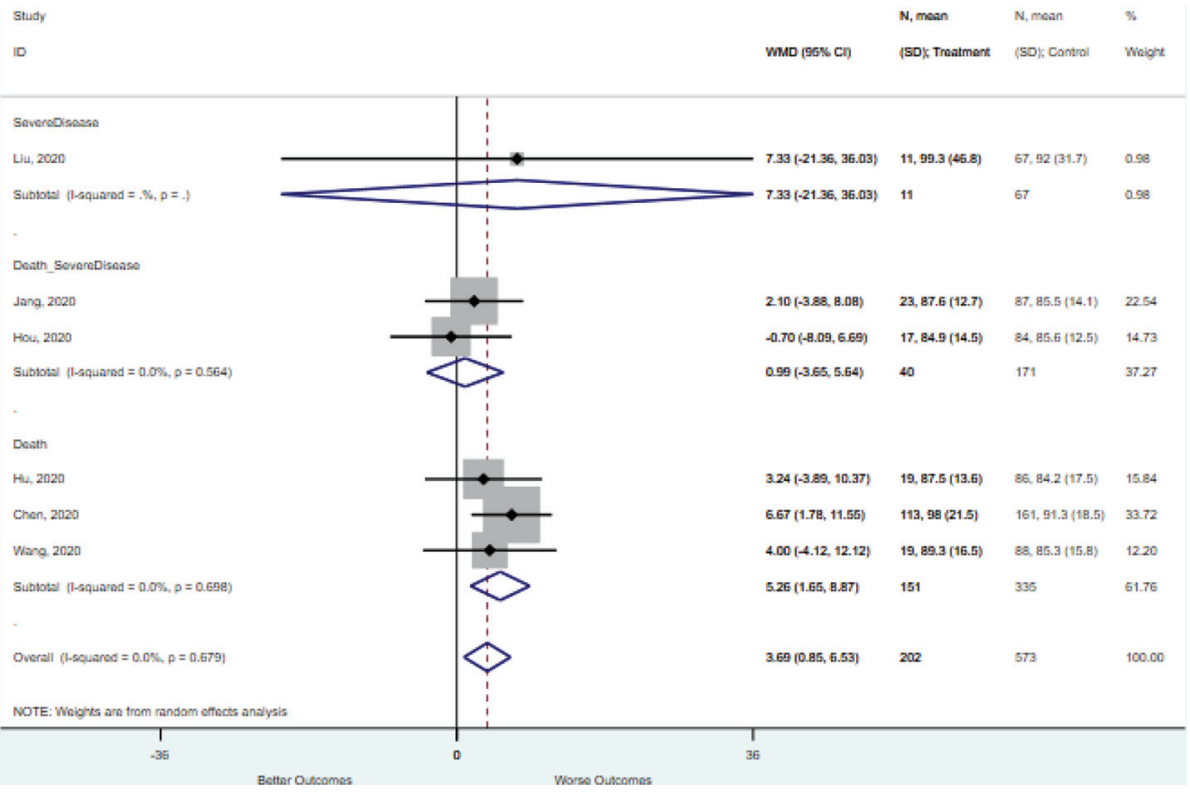


Lymphocyte count

$-0.60(-0.81,-0.39) 286.8(.4) \quad$ 58. $1.4(.8) \quad 5.97$ $-0.48(-0.63,-0.32) 19, .743(.306) \quad 179,1.22(.53) 6.39$ $-0.36(-0.76,0.04) 11, .65(.542) \quad 67,1.02(.535) \quad 4.32$ $-0.37(-0.49,-0.24) 84, .717(.373) \quad 117,1.08(5.55)(6.59$

$\begin{array}{ll}-0.42(-0.70,-0.15) 15,797(.632) & 111,1.22(.472) 5.41 \\ -0.44(-0.52,-0.36) 416 & 5.32\end{array}$

Wu, 2020

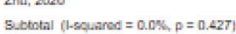

$-0.44(-0.52,-0.36) 416$

$-0.60(-0.82,-0.38) 17, .7(.3) \quad 84.1 .3(.8) \quad 5.87$

$0.80(-0.98,-0.62) 131.7(-4) \quad 1459,1.5(3.3) 6.20$

$-0.90(-1.09,-0.71) 23, .7(.3) \quad 87,1.6(.7) \quad 6.13$

$-0.10(-0.13,-0.07) 900.8(.444) \quad 1739,9(4.444) 6.97$

$-0.75(-0.87,-0.63) 18, .553(.12) \quad 90,1.3(.526) \quad 6.53$

$-0.63(-1.03,-0.22) 1179 \quad 3462 \quad 31.81$

$-0.47(-0.56,-0.38) 113,567(.222) 161,1.03(.519) 6.79$ $-0.27(-0.37,-0.17) 84, .96(.341) \quad 214,1.12(.496) 6.75$ $-0.17(-0.39,0.05) 19.8(.45) \quad$ 8g, $967(.45) \quad 5.87$ $-0.48(-0.58,-0.37) 156, .607(.289) 144,1.08(.57) 6.72$

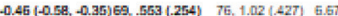
$-0.50(-0.61,-0.39) 54, .633(.224) \quad 137,1.13(. .723) 6.71$ $-0.41(-0.50,-0.32) 494 \quad 820 \quad 39.51$

Xis, 20000 (valld

zhou, 2000

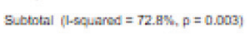

OWonll (l-squared $=952 \mathrm{Ka}, p=0.000$ )

$-0.48(-0.62,-0.35) 2089$

NOTE: Weights ans from rascom antocts analyas

Mean arterial pressure

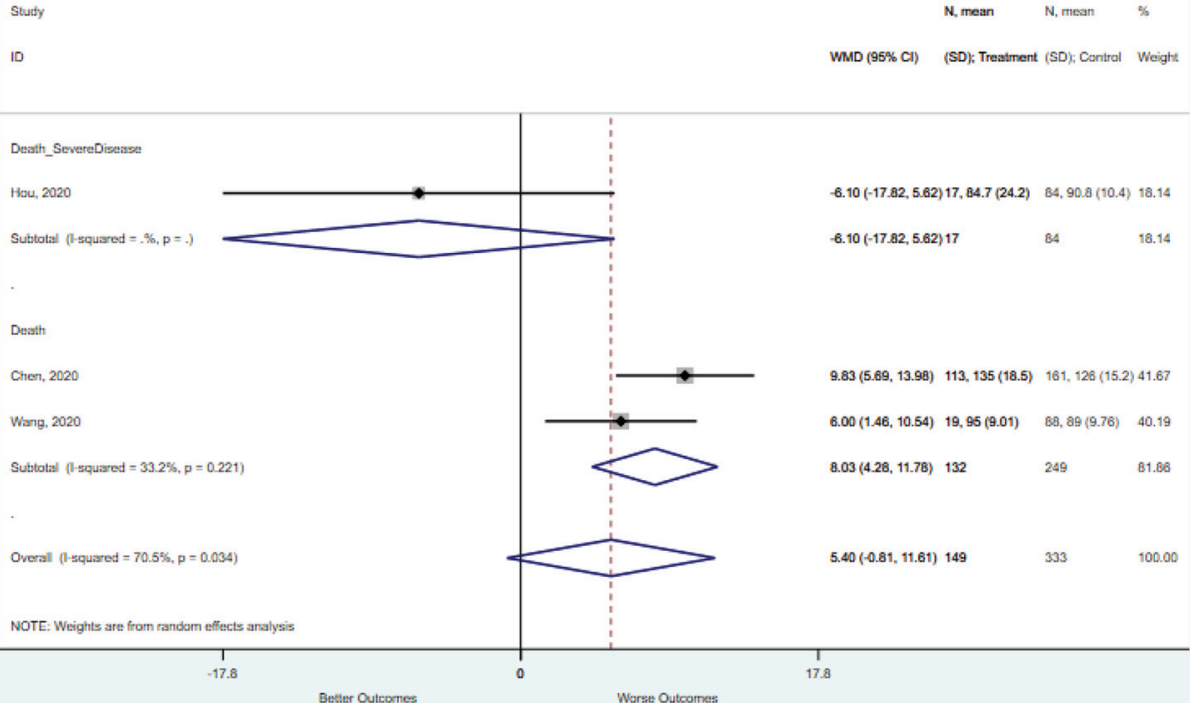


Oxygen saturation

Procalcitonin

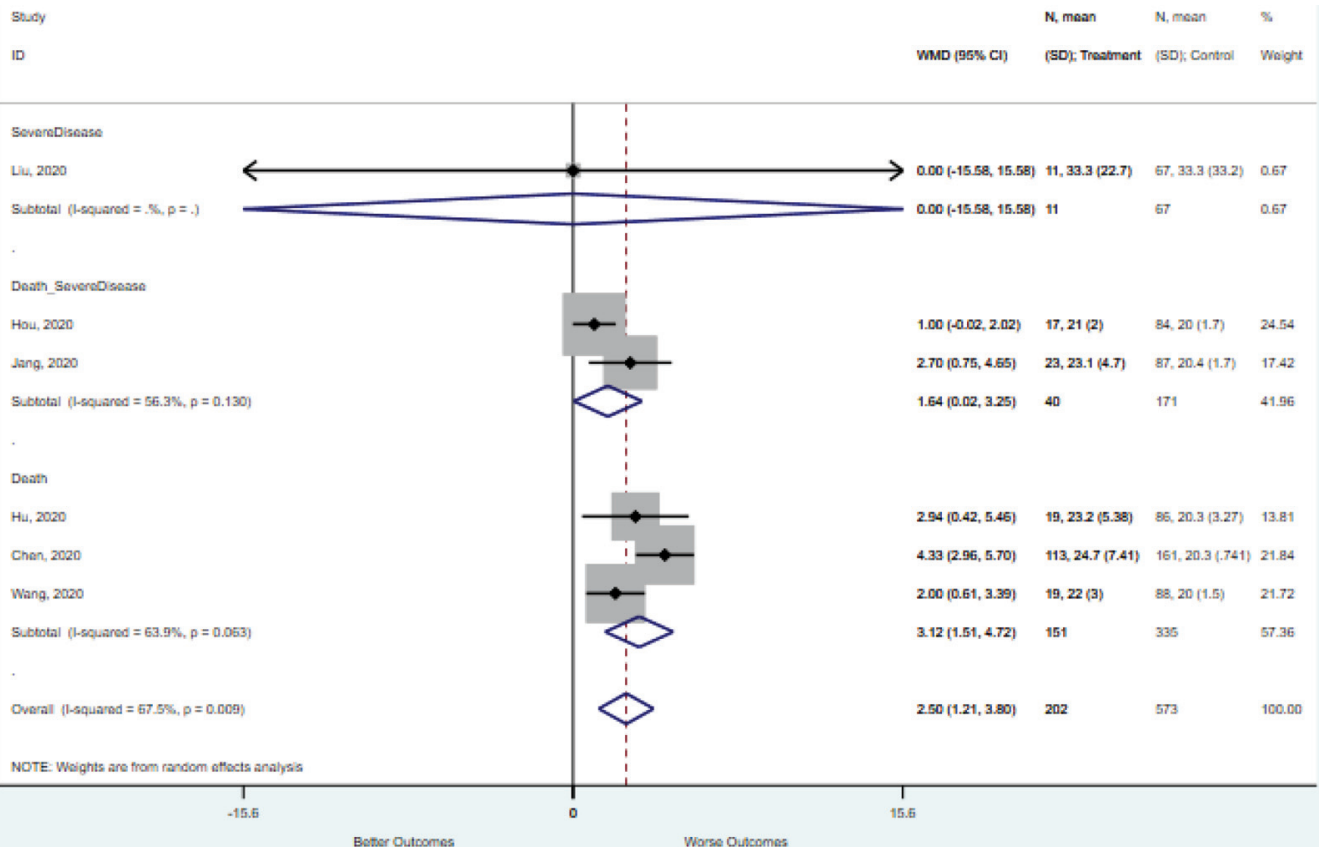


Respiratory rate

Systolic blood pressure

$\begin{array}{lll}\text { WMD }(05 \% \mathrm{Cl}) & \text { (SD): Treatment } & \text { (SD): Control Weight }\end{array}$

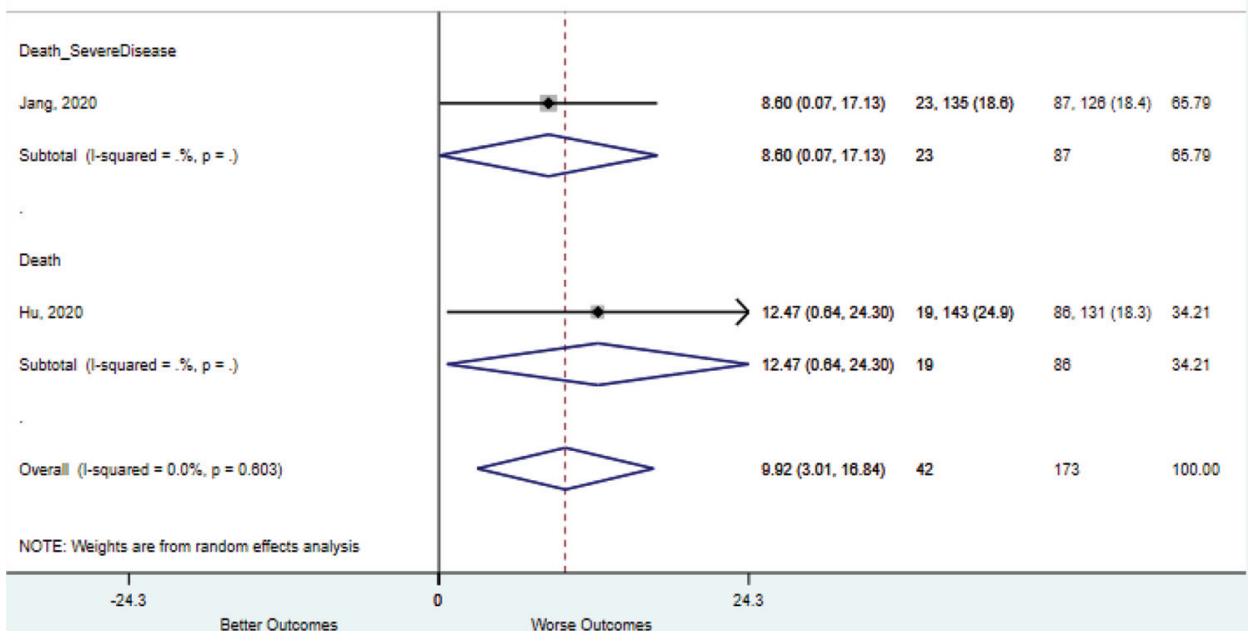

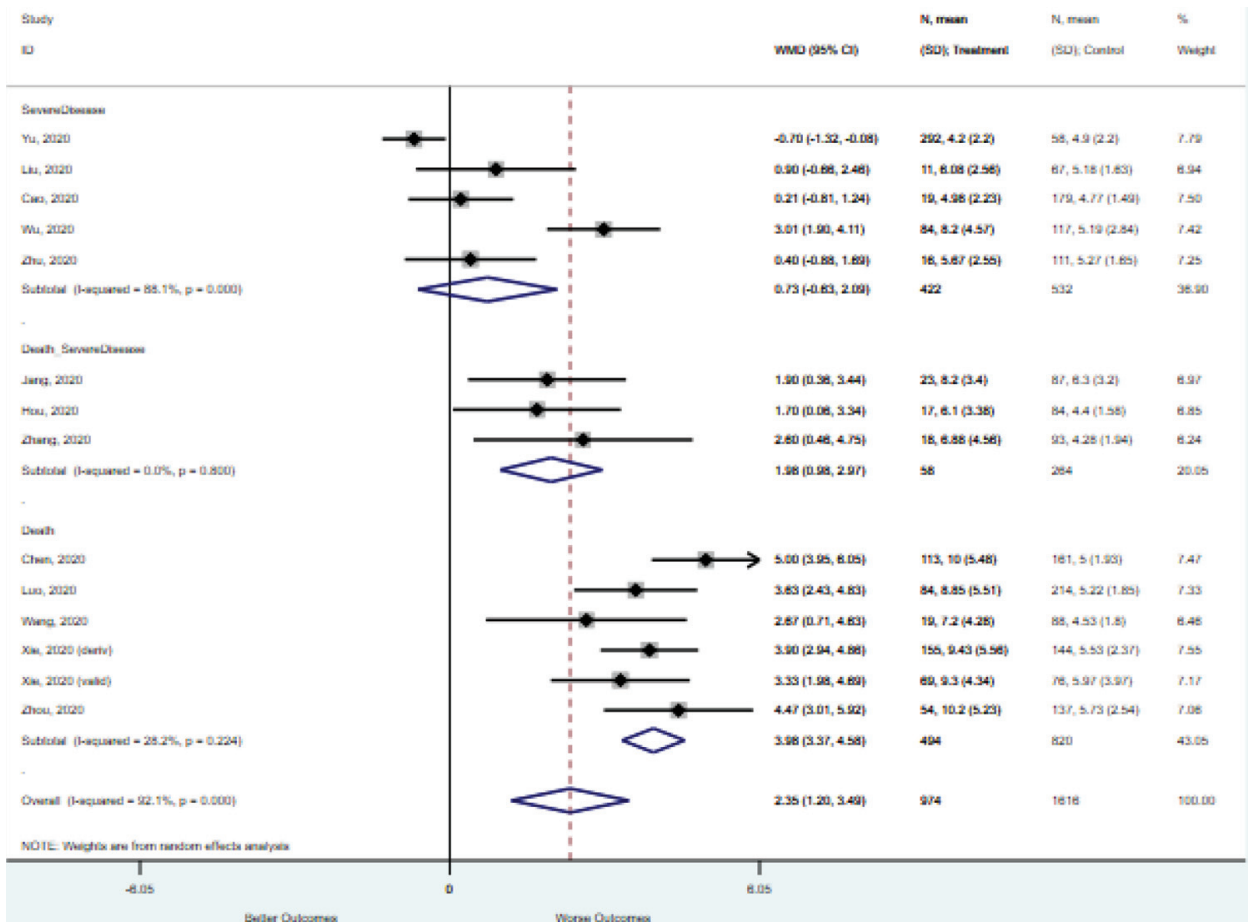


WBC count

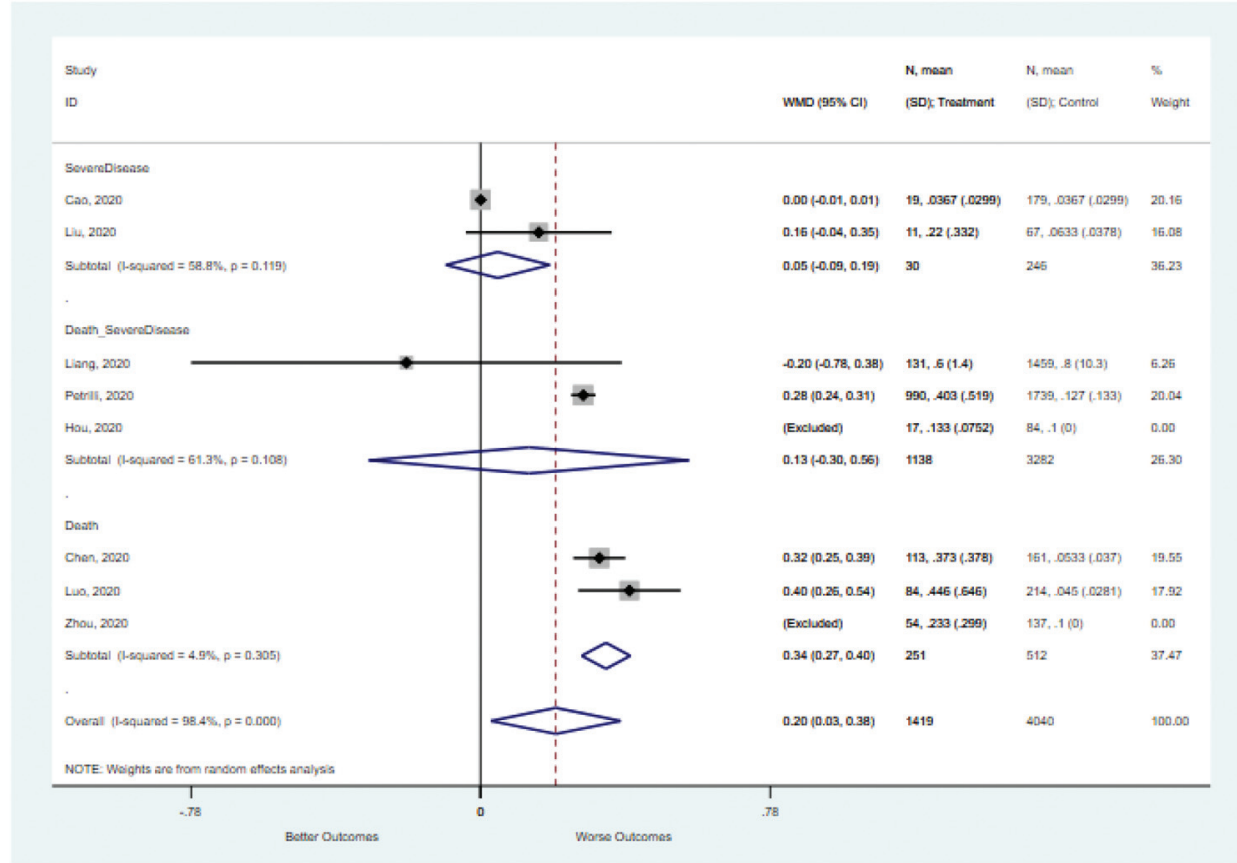

COPD $=$ chronic obstructive pulmonary disease. 